\title{
Dizajnerska kultura in nagrada za oblikovalske dosežke
}

Armand Faganel

Vera Fois 
University of Primorska Press

Editorial Board

Gregor Pobežin

Maja Meško

Vito Vitrih

Silva Bratož

Aleksandra Brezovec

Ana Petelin

Janko Gravner

Krstivoje Špijunović

Miloš Zelenka

Jonatan Vinkler

Alen Ježovnik
Faculty of Management Monograph Series

Editor in Chief

Matjaž Novak

Editorial Board

Ana Arzenšek

Štefan Bojnec

Dubravka Celinšek

Armand Faganel

Viktorija Florjančič

Borut Kodrič

Suzana Laporšek

Mirko Markič

Franko Milost

Matjaž Nahtigal

Mitja Ruzzier

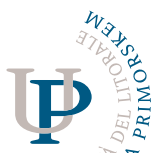

UNIVERS Z 


\section{Dizajnerska kultura in nagrada za oblikovalske dosežke}

Armand Faganel

Vera Fois

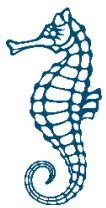


Dizajnerska kultura in nagrada za oblikovalske dosežke

Armand Faganel

Vera Fois

Recenzenta

Boštjan Antončič

Marijana Sikošek

Jezikouni pregled: Davorin Dukič

Prelom: Špela Debelec, Gabrijela Cojzer, Dorina Kiralj

Priprava za izdajo: Jonatan Vinkler

Izdala

Založba Univerze na Primorskem

(za založnika: prof. dr. Dragan Marušič, rektor)

Titov trg 4, SI-600o Koper

Glavni urednik

Jonatan Vinkler

Vodja založbe

Alen Ježovnik

Koper 2018

ISBN 978-96I-7055-00-9 (pdf)

http://www.hippocampus.si/ISBN/978-96I-7055-00-9.pdf

ISBN 978-96I-7055-0I-6 (html)

http://www.hippocampus.si/ISBN/978-96I-7055-0I-6/index.html

DOI: https://doi.org/10.26493/978-96I-7055-00-9

(C) 2018 Univerza na Primorskem

Izdaja je sofinancirana po pogodbi ARRS za sofinanciranje izdajanja znanstvenih monografij v letu 2018.

Kataložni zapis o publikaciji (CIP) pripravili v Narodni in univerzitetni knjižnici

v Ljubljani

COBISS.SI-ID $=295504384$

ISBN 978-96I-7055-00-9 (pdf)

ISBN 978-96I-7055-0I-6 (html) 


\section{Vsebina}

\section{$7 \quad$ Slike in preglednice}

\section{Uvod}

Io Oblikovanje

I2 Znamčenje

I2 Kultura organizacij

I4 Metodološke omejitve

I4 Vsebinske omejitve

17 Kultura

I8 Kultura kot družbena kategorija

I9 Kultura kot menedžerska kategorija

19 Organizacijska kultura

19 Korporativna kultura

$2 I \quad K u l t u r a k o t o b l i k o v a l s k a k a t e g o r i j a$

22 Modela kulture oblikovanja

23 Kultura oblikovanja po Julierju

24 Model kulture oblikovanja po Julierju

25 Proizvodnja

26 Potrošnja

28 Oblikovanje

29 Vloga oblikovalcev

\section{I Identiteta}

3 I Korporativna identiteta

32 Identiteta zaposlenih

33 Zakaj je identiteta pomembna

33 Znamčenje 
34 Kultura oblikovanja po Dessertiju in Rizzu

37 Oblikovanje v organizacijah

37 Oblikovalski vidik

4I Menedžerski vidik

43 Design thinking

43 Kaj je oblikovalsko mišljenje (design thinking)

45 Menedžerski pogled na oblikovalsko mišljenje

47 Metodologija

48 Namen in cilji

48 Raziskovalna vprašanja

49 Vzorec

50 Metode zbiranja podatkov

5I Triangulacija

5I Metode analize podatkov

5I Predvidene omejitve in predpostavke pri obravnavanju problema

5I Metodološke omejitve

52 Vsebinske omejitve

52 Red Dot Award

53 Analiza in interpretacija

53 Kam gremo?

54 Trend

6I Strategija

69 Kultura oblikovanja

69 Inovacije

73 Ljudje

78 FFF - Form follows function

83 Nagrade

83 Ples na trgu

89 Dober sem

9I Sklep

9I Zaključki in ugotovitve

95 Predlogi za nadaljnje raziskovanje

95 Predlogi za prakso

97 Povzetek

I05 Summary

113 Literatura

I25 Stvarno kazalo 


\section{Slike in preglednice}

17 Slika I: Ravni kulture

25 Slika 2: Model kulture oblikovanja

29 Slika 3: Povezanost med proizvodnjo, potrošnjo, identiteto, pojavnostjo in regulacijo

35 Slika 4: Kultura oblikovanja

I8 Preglednica i: Pregled definicij kulture

20 Preglednica 2: Opredelitve korporativne kulture

27 Preglednica 3: Kritične teorije o potrošništvu

28 Preglednica 4: Potrošnja

32 Preglednica 5: Korporativna identiteta

32 Preglednica 6: Ključni koncepti poklicne identitete

37 Preglednica 7: Skupine definicij oblikovanja, ki so jih razvili oblikovalci

44 Preglednica 8: Design thinking 



\section{Uvod}

Sodobna družba je kompleksna, intenzivna in predvsem družba podob in potrošništva. To kompleksno družbeno okolje sestavljamo posamezni$\mathrm{ki}$, podjetja in različne institucije. Opredelitev našega okolja je veliko in izhajajo iz različnih družboslovnih in ekonomskih disciplin, vendar je vsem skupno, da današnje okolje opredeljujejo pojmi, kot so hitre spremembe, informatizacija in globalizacija, kar Bauman (2004) pojasnjuje in utemeljuje, ko pravi, da naša življenja prežemajo globalni procesi.

Da bi podjetja ohranila svojo konkurenčnost in obstala na trgu, se morajo hitro prilagajati in iskati nove načine, kako in katere produkte in storitve proizvajati ter kako jih tržiti. Cameron idr. $(2006,9)$ pravijo, da je življenjska doba skoraj katere koli tehnologije na planetu kratka, večinoma manj kot šest mesecev. Isti avtorji poudarjajo, da je treba povprašati vodilne v Microsoftu, Amazonu in drugih podjetjih, ki hitro prilagajajo storitve in izdelke potrebam na hitro spreminjajočih se trgih, kaj in kako delajo, da ostajajo vodilni na svojih področjih. Tako kaže, da bodo tisti, ki so počasni in preveč konservativni v razvoju novih izdelkov, zaostali.

Zato moramo osvetliti okolje, v katerem delujemo kot posamezniki, tako proizvajalci kot potrošniki. To okolje ni zgolj »prazno okolje «, ki ga polnimo s podobami, resnicami in idejami, ampak je okolje kultura, ki je Kneževič (20I4, 2I) ne razume kot napredovanje civilizacije, temveč kot »oblikovano in doživeto idejo resnice znotraj družbe «. Idejo resnice sicer nenehno preverjamo, se o njej sprašujemo. Del tega spraševanja je lahko povezan z estetiko in estetizacijo, kjer na obliko gledamo, kot da ima lastno vrednost. 
$\mathrm{V}$ času hitrega tehnološkega napredka in padanja meja postaja pomembna in poglavitna konkurenčna prednost oblikovanje. Kot pravi Julier (2006), je oblikovanje ne le ustvarjanje vizualnih podob, izdelkov znotraj vizualnega in materialnega sveta, temveč ustvarjanje sistemov, ki se pojavljajo znotraj vizualnega in materialnega sveta. Malosi, Popovic in Hickling-Hudson (2007, I) pravijo, da kultura ustvarja različnosti in je razkrita v vsaki človeški aktivnosti, vključno z izdelki, ki jih oblikujejo ljudje. V tem kontekstu je kultura del vrednotnega sistema, in sicer njegov dinamični del, $\mathrm{v}$ katerem se nenehno vrednotijo in prevrednotijo oblike in pomeni. Ta »oblikovalski pogled « postavlja kulturo v vrednotni sistem, s čimer se loči od menedžerskega vidika razumevanja kulture organizacije, ki postavi $\mathrm{v}$ središče razumevanja kulture vrednote. Na nek način se $\mathrm{v}$ oblikovanju oblikujejo oblike in pomeni ter $\mathrm{s}$ tem tudi ideje resnice.

Tudi podjetja so družbeni sistemi s svojimi vrednotami, kulturo, sistemi delovanja. Prek različnih sistemov in procesov ter aktivnosti skušajo podjetja svoje vrednote prenesti na svoje zaposlene, ki naj bi ravnali v skladu z njimi. Po drugi strani skušajo podjetja svoje vrednote, ki so vgrajene vizdelkih in storitvah prek znamčenja' in drugih posrednikov, posredovati potrošnikom, kupcem. Pri tem nosi pomembno vlogo oblikovanje, ki je močno prepleteno s podjetništvom. Pri oblikovanju gre namreč za ustvarjanje predmetov, podob in sistemov, ki so del podjetniškega sveta.

$\mathrm{Za}$ opredelitev raziskovalnega problema nas zanimajo trije ključni koncepti. Oblikovanje, znamčenje in organizacijska kultura.

\section{Oblikovanje}

$\mathrm{Z}$ razvojem oblikovanja, managementa in podjetništva je prišlo do mnogih sprememb v poslovnem okolju. Po drugi strani se podjetja vedno bolj zavedajo pomena oblikovanja, in to ne le kot oblikovanja lepih izdelkov, temveč kot načina mišljenja in delovanja, ki temelji na prepletu sistemov vrednot podjetja, kupca in potrošnika.

Zavest o pomembnosti oblikovanja je od nekdaj prisotna. V zadnjih 30 letih se skupaj z oglaševanjem in znamčenjem še bolj razvija in stopa $\mathrm{v}$ ospredje. Tako so mnoge oblikovalske agencije razširile svoje področje delovanja še na svetovanje podjetjem s področja znamčenja in obrnjeno nekatere oglaševalske agencije storitve oblikovanja. Tako se je začelo razvijati področje design managementa, ${ }^{2}$ ki ponuja nekatere praktične nas-

V slovenskem prostoru se za znamčenje bolj uporablja izraz branding.

Design management je izraz, ki se ukvarja s tem, kako ustvariti kreativno okolje v organizaciji, ki spodbuja oblikovanje kot strateško usmeritev podjetja. 
vete in rešitve podjetjem. Avtorji Borja de Mozota (2003), Brown (2009), Jenkins (2009) in Best (2010) pravijo, da design managementa podpira predvsem razvoj kulture oblikovanja znotraj podjetij, ta pa naj bi podjetjem prinesla konkurenčne prednosti. Ti avtorji izpostavljajo kot ključni dimenziji konkurenčne prednosti znamčenje in inoviranje. Tudi Julier (20I4), ki je opredelil kulturo oblikovanja, izpostavlja znamčenje kot povezovalni člen.

Vrsta avtorjev izpostavlja inoviranje kot ključni proces $\mathrm{v}$ podjetju. Lee in Benza (2015) potrjujeta, da je inoviranje glavni vir diferenciacije in konkurenčne prednosti $\mathrm{v}$ čedalje kompleksnejšem in hitro spreminjajočem se poslovnem okolju 21. stoletja. Russell-Bennettova in Baron (2015) trdita, da le nov, svež način razmišljanja poganja razvoj.

Tudi slovenska podjetja delujejo v globalnem okolju, ki se hitro spreminja, zato se morajo na spremembe odzivati hitro in prožno. Spreminjanje in hitro odzivnost lahko dosežejo $z$ načinom delovanja, to je, da uporabljajo oblikovalski način razmišljanja. Eden od načinov povečevanja konkurenčnosti je torej tudi spodbujanje dizajnerskega razmišljanja ${ }^{3}$ in dizajnerske kulture $\mathrm{v}^{\mathrm{v}} \mathrm{podjetjih.}$

Johansson-Skoldbergova, Woodilla in Cetinkaya (2013, I2I) opisujejo paradoks, ki pravi: $\mathrm{V}$ menedžerskem okolju je dizajnersko razmišljanje opredeljeno kot najboljši način biti kreativen in inovativen. $\mathrm{V}$ oblikovalskem okolju pa dizajnersko razmišljanje delno ignorirajo in ga jemljejo kot nekaj samoumevnega.« Avtorji vzpostavljajo dva pojma, to sta način $\gg$ biti« in »razmišljanje «. Oblikovanje razmišljanje in identiteta (biti). Pri tem avtorji uporabljajo dva različna izraza, prvi je design thinking, kot ga uporabljajo v poslovnem svetu, drugi pa designerly thinking, kot je uporabljen v oblikovalskem okolju. Tako opredelijo oblikovalsko mišljenje (design thinking) kot poenostavljeno različico mišljenja oblikovanja (designerly thinkinga). Ross (2015) trdi, da je oblikovalsko (dizajnersko razmišljanje) nekaj, kar je že inherentno znotraj človeške kognicije; je ključni del tistega, kar nas dela ljudi. Rosenberg, Chauvet in Kleinman (2015) menijo, da je lahko design thinking vir konkurenčne prednosti, če je vgrajen $\mathrm{v}$ korporativno kulturo, kakor tudi v strategije, procese in prakse, sisteme in strukture. Kadar podjetja uporabljajo ali želijo uporablja-

\footnotetext{
V literaturi se pojavljata dva pojma, to sta 'design thinking' in 'designerly thinking'. Oblikovalsko mišljenje je prevod besede design thinking. Designerly thinking pa lahko prevedemo kot mišljenje oblikovanja. Zaradi pomanjkanja slovenskih prevodov in razlag bom v nadaljevanju teksta v oklepajih navajala angleška izraza. V slovenski literaturi smo zasledili zgolj termin dizajnersko razmišljanje, ki ustreza pojmu design thinking, ne pa tudi ustreznega prevoda za designerly thinking.

4 Dizajnersko kulturo prevajamo kot oblikovalsko kulturo in tako v tekstu tudi pišemo.
} 
ti oblikovalsko mišljenje (design thinking) v svojem okolju, je, kot pravi Buchanan (1992), pomembno predvsem to, kako razmišljajo o reševanju kompleksnih problemov, kjer je možnih več rešitev.

Znotraj tega menedžerskega diskurza se design thinking še naprej deli $v$ način upravljanja oblikovanja in inovacij kot upravljanje in reševanje problemov znotraj organizacije ter kot sestavni del menedžerske kulture.

\section{Znamčenje}

Anholt (2003) pravi, da je vrednost znamke multiplikator vrednosti, in znamka kot taka predstavlja prednost za lastnika. Namen znamke je komuniciranje s trgom. Znamka predstavlja vrednote podjetja in tako omogoča kupcu lažjo odločitev. Gre za to, da je znamka simbol za vrednote podjetja, ki jih to posreduje kupcu. Zato avtorji, med drugimi Anholt (2003), izpostavljajo troje: (a) da je ime znamke obljuba, (b) da so bila velika sredstva vložena v izdelek in (c) da ta izdelek deluje tako, kot ime obljublja. Schultz in de Chernatony (2002) sta postavila opredelitev, kjer je predstavljen širši vidik znamčenja: »Znamčenje omogoča managementu celosten okvir za usklajevanje različnih aktivnosti, s katerimi podjetje izraža, kdo je in za kaj se zavzema.« Palomaa (2013) pravi, da blagovna znamka z ustvarjanjem obljub vzpostavlja odnose s svojimi deležniki - da bi te obljube uresničila, pa potrebuje inovacije. Inoviranje lahko izpolnjuje obljube blagovne znamke; skozi inoviranje posreduje znamka resnično in otipljivo vrednost odjemalcem $\mathrm{v}$ obliki novih izdelkov, storitev ter izkušenj (Abbing 2010).

Za preplet vrednot, ki usmerjajo delovanje podjetja, pravi Urde (200I), da so za znamčenje potrebni trije sklopi vrednot: notranje vrednote, ki so povezane z organizacijo, vrednote, ki opredeljujejo znamko, in vrednote, kot jih doživlja kupec. Notranje vrednote so organizacijske vrednote, življenjska pravila, kot pravi Urde (200I). Osnovne vrednote, ki ustvarjajo znamko, so jedro vrednot. Tvorijo bistvo znamke. Vrednote, ki jih zaznava kupec, pa so tiste, ki znamki prinesejo dodano vrednost. Ta dodana vrednost za kupca je lahko emocionalna, simbolična ali uporabna. Ravno to dodano vrednost lahko $\mathrm{v}$ veliki meri dosežemo ravno z oblikovanjem.

\section{Kultura organizacij}

Eden od ciljev knjige je opredelitev dizajnerskega mišljenja, kot je opredeljeno v menedžerskem okolju. Organizacijam je v veliko pomoč pri njihovem delovanju, usmerjanju in ohranjanju konkurenčnosti organizacijska kultura. Desserti in Rizzo (2014) menita, da je razmerje med dizajnom in 
svetom proizvodnje vedno nihalo med dvema pogledoma: med redukcionističnim vidikom dizajna kot ene izmed veščin v proizvodnem procesu, ki jo potrebujemo za povečanje privlačnosti izdelka, in kulturnim vidikom dizajna kot tistega enkratnega sistema kompetenc, znanja in veščin, ki (vključno s predmeti, praksami, vrednotami in prepričanji, ki pripadajo dizajnerski kulturi) lahko prepoznajo inovativne rešitve, ki zadovoljujejo eksplicitne ali latentne potrebe ob vključevanju različnih omejitev. Chatman in Eunyoung Cha (2003) navajata, da je kultura sistem skupnih vrednot (opredeljujejo, kaj je pomembno) in norm (opredeljujejo ustrezen pristop in vedenje). O pojmu organizacijska kultura kot pomembnem dejavniku oblikovalskega mišljenja velja pripomniti, da v oblikovalskih virih in literaturi zasledimo izraz korporativna kultura, $v$ menedžerski literaturi pa je veliko zapisov o organizacijski kulturi in njenih različnih tipologijah. Organizacijska kultura je torej lahko razumljena kot sinonim korporativne kulture ali pa je korporativna kultura vrsta organizacijske kulture, o čemer bomo podrobneje pisali v poglavju o kulturi. V tem uvodnem poglavju uporabljamo izraza kot sinonima.

Rosenberg, Chauvet in Kleinman (2015) ugotavljajo, da je vpliv organizacijske kulture na dizajnersko razmišljanje kritičen. Kotter in Heskett (1992) pravita, da je najustreznejša tista organizacijska kultura, ki vsebuje vrednote in norme, ki podpirajo inovacije in spremembe. Donker, Poff in Zahir (2008) so v empirični raziskavi ugotovili pozitivno in visoko statistično povezanost med organizacijskimi vrednotami in poslovnimi rezultati podjetja. Da pa je organizacijska kultura dejansko lahko strateška prednost, pravi Barney (1986), mora biti kultura pomembna, voditi mora podjetje $\mathrm{k}$ ekonomski uspešnosti, biti mora posebna, imeti lastnosti in značilnosti, ki jih nima veliko podjetij. Kot lahko vidimo iz opredelitve organizacijske kulture, lahko ta vsebuje tudi način razmišljanja, delovanja. $\mathrm{V}$ tem primeru dizajnerski način razmišljanja. Julier (2013) trdi, da se je kultura oblikovanja kot široko uporabljan termin uveljavila v prejšnjem desetletju, analitično pa opisuje sodelovanje domen dizajna, proizvodnje in potrošnje, znotraj katere domujejo vprašanja vrednosti, kroženja in prakse.

Uspešnost na trgu je ena od osnovnih postavk, zakaj podjetje sploh obstaja. Kot lahko vidimo, podjetja delujejo v globalnem okolju, kjer je močno prisotna dizajnerska kultura. Že zaposleni so del tega okolja in tovrstne vrednote in vedenja delno prinesejo s seboj v delovno okolje. Po drugi strani vidimo, da so uspešna podjetja tista, ki se zavedajo svojega kulturnega okolja, ki sledijo spremembam in inovacijam, te pa dosegajo z oblikovalskim načinom mišljenja kot osnovnim načinom delovanja. Raz- 
iskave kažejo, da so na trgu uspešna tista podjetja, ki imajo močno in posebno kulturo, katere sestavni del so vrednote sprememb in inovacij. V delu smo raziskali razumevanje koncepta dizajnerska kultura, teoretično in empirično proučili pomen, ki ga podjetja, ki so osvojila prestižno dizajnersko nagrado Red Dot Design Award, pripisujejo kulturi oblikovanja. Prepletata se dva vidika, menedžerski in oblikovalski, ki naj bi se združila v konceptu oblikovalske kulture.

'Red Dot Design Award" je mednarodna nagrada za oblikovanje izdelka in oblikovanje komunikacije, ki jo že od leta I955 podeljuje Design Zentrum Nordrhein Wesfalen v Essnu v Nemčiji. Obstajajo kategorije za oblikovanje izdelka, oblikovalske agencije in oblikovalske koncepte. Zmagovalni projekti so predstavljeni v muzeju Red Dot Design v Essnu in na Tajvanu. Leta 2014 so prejeli več kot 15.500 prijav iz 70 držav sveta (Red Dot b. 1.).

\section{Metodološke omejitve}

Ta študija je eksploratorna (Sagadin 2004), kar pomeni, da smo naredili prvi vpogled $\mathrm{v}$ preučevani problem, zato smo se prilagajali situacijam $\mathrm{v}$ podjetjih. Podjetja so različna po velikosti, strukturi, intenzivnosti oblikovanja, zato je treba to razumeti kot metodološko omejitev. Prav tako ne moremo naših ugotovitev posploševati. Imena vključenih podjetij in intervjuvancev ohranjamo anonimna, saj so bili le tako pripravljeni sodelovati.

\section{Vsebinske omejitve}

Vsebinske omejitve so povezane $\mathrm{z}$ dejstvom, da je področje dizajn managementa empirično slabo raziskano. Obstaja pa veliko svetovalnih podjetij, katerih predmet delovanja je dizajn management. Vsebinsko omejitev smo implicitno zapisali in jo je mogoče razbrati iz namena raziskave. Omejili smo se le na tri vidike: organizacijsko kulturo, oblikovanje in dizajn management, možno pa bi bilo zajeti tudi druge vidike, kot so filozofski, sociološki, marketinški, potrošniški ipd.

Posebna omejitev in hkrati izziv je prevod angleških izrazov, ki so uveljavljeni v slovenskem prostoru. Terminologija s tega področja ni razvita, kar kaže na slabo poznavanje tega področja in $s$ tem razvoja sloven-

5 Red dot nagrada je precej poznana tudi v slovenskem prostoru, zato smo jo izbrali za kriterij presoje dobrega oblikovanja. Nihče v strokovnih krogih ne uporablja izraza rdeča pika, saj vsi razumejo originalno poimenovanje kot lastno ime. Prav tako je pojem red dot prepoznan v javnosti, kar za slovenski prevod ne moremo reči. 
ske terminologije. V monografiji ohranjamo angleške izraze in v oklepajih slovenske prevode, kot smo jih opredelili sami. Vsekakor so podani zgolj kot predlog, ki ga lahko stroka sprejme, spremeni ali dopolni. Prav tako je $\mathrm{v}$ slovenskem in mednarodnem prostoru poznavanje dizajn managementa in področij, ki to obravnavajo, novo, zato ni relevantne literature, ki bi osvetlila nekatere osnovne pojme. Zato je bila posebna skrb namenjena pravilni opredelitvi osnovnih pojmov. Prav tako velja zapisati, da $\mathrm{v}$ nalogi večkrat dobesedno navajamo opredelitve, definicije ključnih avtorjev, posebno na področju oblikovanja, ki vstopa in se prepleta s področjem managementa.

V nadaljevanju dela so predstavljeni in kritično pojasnjeni pojmi, kot so oblikovanje, kultura in kultura oblikovanja, povezanost oblikovanja in organizacijske kulture. Raziskali smo, kako razvijajo kulturo oblikovanja kot način mišljenja $\mathrm{v}$ slovenskih proizvodnih podjetjih, ki so prejela nagrado red dot, ki je znamenje oblikovalske odličnosti. Predstavili smo potek empiričnega dela, zbiranje podatkov, analizo podatkov in ugotovitve ter sklepe. 



\section{Kultura}

Kultura je kompleksen pojem, ki ga različni avtorji obravnavajo različno in v različnih kontekstih. Ena od možnih obravnav je, da pogledamo kulturo s splošnega sociološkega vidika, menedžerskega vidika in oblikovalskega vidika. Prav tako lahko kulturo pogledamo skozi kulturološki, organizacijski oziroma menedžerski in oblikovalski vidik. Mogoče pa je kulturo pogledati skozi nivoje: individualna, organizacijska, nacionalna ter globalna kultura.

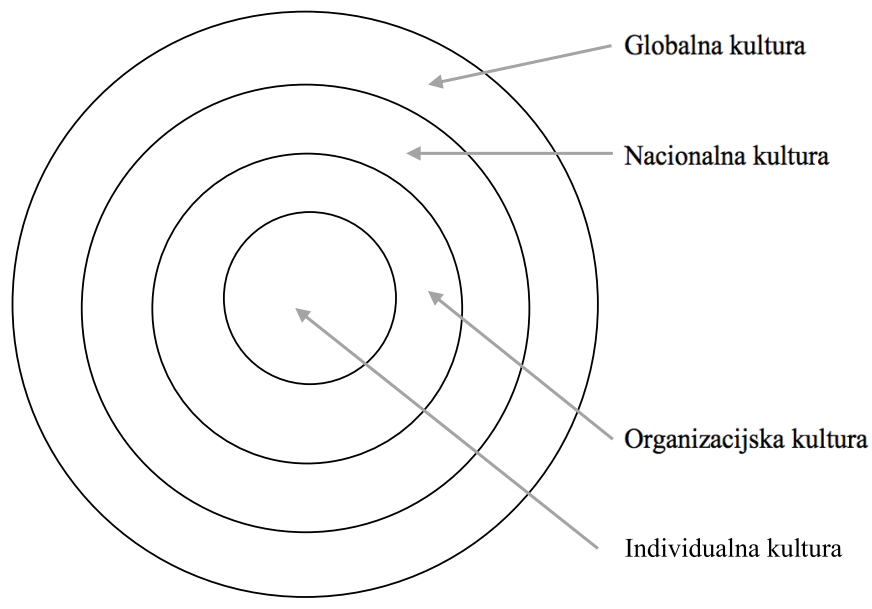


Pomembna raziskovalca korporativne kulture Cameron in Quinn (2006, 17) pravita, da obstaja več nivojev kulture, ki vplivajo na posameznika in organizacije. Pri tem se opirata na raziskave po Hofstede in Minkov (1991) ter Trompenaars in Hampden-Turner (1998), ki pravijo, da če pogledamo strukturirano, po nivojih, potem je na najširšem oziroma najvišjem nivoju globalna kultura. Naslednji nivo so nacionalne kulture in razlike, ki temeljijo na osnovi univerzalizma proti partikularizmu, individualizma proti kolektivizmu, nevtralnosti proti emocionalnosti. Na spodnjem nivoju so subkulture, kulture na osnovi spola, poklica, regionalne. Pri tem podata splošno opredelitev kulture, pri čemer poudarita, da vsaka kultura odseva svoj jezik, simbole, pravila in etnocentrične občutke, Cameron in Quinn $(2006,17)$. Vsi nivoji kulture pa so prisotni v organizaciji in posamezniku. $\mathrm{V}$ tabeli I podajamo nekaj opredelitev kulture skozi kulturološki vidik.

Preglednica r: Pregled definicij kulture

\begin{tabular}{ll}
\multicolumn{1}{c}{ Avtor } & \multicolumn{1}{c}{ Citat } \\
\hline Cameron in Quinn 2006, I7 & Vsaka kultura odseva svoj jezik, simbole, pravila in etnocentrične občutke. \\
\hline Peper 20I2 po Kneževič 20I4, 2I & $\begin{array}{l}\text { Ne razume kulture kot napredovanja civilizacije, temveč kot »oblikovano in } \\
\text { doživeto idejo resnice znotraj družbe«. }\end{array}$ \\
\hline $\begin{array}{l}\text { Malosi, Popovic in Hickling } \\
\text {-Hudson 2007, I }\end{array}$ & $\begin{array}{l}\text { Kultura ustvarja različnosti in da je ta razkrita v vsaki človeški aktivnosti, vključ- } \\
\text { no z izdelki, ki jih oblikujejo ljudje. }\end{array}$ \\
\hline $\begin{array}{l}\text { Malosi, Popovic in Hick- } \\
\text { ling-Hudson 2007,3 }\end{array}$ & $\begin{array}{l}\text { Kultura je dinamično telo vrednotnega sistema, ki ga spreminjajo družbene spre- } \\
\text { membe. Je dialektično in vsebuje nove oblike in pomene, medtem ko oblikuje } \\
\text { ali preoblikuje tradicionalne. }\end{array}$ \\
\hline
\end{tabular}

Iz navedenih definicij kulture različnih avtorjev lahko vidimo, da je značilna lastnost kulture sprememba. Kultura se prek različnih procesov nenehno spreminja, kar se odraža v različnih aktivnostih, vrednotah, načinih delovanja in materialnih izdelkih, ki odražajo neko kulturo. Navsezadnje tudi o preteklih kulturah, ki jih preučujejo arheologi, sodimo na podlagi materialnih virov. Tako lahko vidimo, da kultura ni le abstrakten pojem, temveč vse, kar nas obdaja. Ves materialni svet okoli nas je posledica vrednot in odločitev in s tem odraz kulture. Lahko bi tudi rekli, da je ves svet kultura.

\section{Kultura kot družbena kategorija}

Kumar (4I, 2005) pravi, da je kultura nenehna človekova aktivnost. V jedru aktivnosti so vrednote. Vrednota je osnovana na kulturi. In če je tako, potem se kultura razvija in hkrati nastaja dobro okolje za razvoj vrednot. 
Vrednote so del socializacijskega procesa. Posameznik se vrašča v kulturo tako, da pridobiva znanje, vrednote in veščine od drugih članov skupnosti. Socializacija je proces kulturalizacije. To se dogaja tudi v podjetju, kjer so vrednote del identitete. $S$ tem je podan okvir delovanja.

\section{Kultura kot menedžerska kategorija}

Velik del sodobne proizvodnje poteka $\mathrm{v}$ organizacijah. Tudi organizacije, najsibodi profitne, neprofitne, proizvodne, storitvene, so družbe (nacionalne kultura) v malem. Imajo svoje načine delovanja, vrednote, cilje in namene. $S$ tem se ukvarjajo strokovnjaki, ki proučujejo organizacije.

Pri tem zasledimo dve poimenovanji, korporativno kulturo in organizacijsko kulturo.

\section{Organizacijska kultura}

Organizacijsko kulturo vrsta avtorjev opredeljuje kot osrednji dejavnik finančnega uspeha organizacij (Schein 2004; Cameron in Quinn 2006). Sestavine organizacijske kulture, če navedemo le po Cameron in Quinn (2006, I6), so stil vodenja, jezik, simboli, postopki, rutine in definicije uspeha, dodali pa bi tudi upravljanje znanja ter vrednotenje zaposlenih kot kapitala družbe. V menedžerskem okolju se zavedajo, da je ravno organizacijska kultura konkurenčna prednost, ki omogoča podjetju razlikovanje na trgu (Gomezelj Omerzel, Biloslavo in Trnavčević 2010 in 201 I; Biloslavo idr. 20I2). Velik del proizvodnje je ustvarjen $\mathrm{v}$ organizacijah in del teh velikih kompleksnih okolij so oblikovalci.

Sodobne organizacije se nenehno sprašujejo, kako izboljšati, povečati konkurenčno prednost na trgih. Pri iskanju novih poti sodelujejo tudi oblikovalci. Ti bi se morali zavedati, da je njihova pomembna vloga v spreminjanju organizacijske kulture. Premalo je, da iščejo in oblikujejo nove funkcionalne prostore, in premalo je, da inovirajo oziroma sodelujejo $\mathrm{v}$ inoviranju (Lockwood 2009, 24). To je vsekakor zanimiv poudarek, ki je povezan tudi z raziskovalnim problemom tega dela, namreč preučevanja dizajnerske kulture oziroma kulture oblikovanja. Kultura lahko postane konkurenčna prednost, če so notranji vzorci različni in neposnemljivi, če so ne le simboli, ampak tudi vrednote ter stili vodij tisti, ki tvorijo spodbudno profesionalno okolje (Barney 1986; Highhouse idr. 1999).

\section{Korporativna kultura}

Korporativno kulturo kot vrednote in načine delovanja, ki so značilni za organizacijo, opredelijo Tellis, Prabhu in Chandy (2009), Denison 
(1996), Deshpandé and Webster (1989), Detert, Schroeder in Mauriel (2000), Hatch (1993), Schein (20049, Schultz in Hatch (1996). Podobno označujejo organizacijsko kulturo kot sistem vrednot, načinov delovanja, jezika (Schein 2004, I8). Korporativno kulturo sestavljajo vrednote, prepričanja in standardi, ki vplivajo na misli in vedenje ljudi v podjetjih in so za organizacijo edinstveni (Hitka idr. 2015, 27).

Preglednica 2: Opredelitve korporativne kulture

\begin{tabular}{ll}
\multicolumn{1}{c}{ Avtor } & \multicolumn{1}{c}{ Opredelitev } \\
Nelson 2003, I06 & $\begin{array}{l}\text { Skupna predvidevanja ali vrednote, pomene, simbole, obrede, organizacijske zgodbe, } \\
\text { žargon, humor, materialni odraz (delovno mesto in predmeti), formalna struktura, pravi- } \\
\text { la in druge eksplicitne ali inferred značilnosti kulture. }\end{array}$ \\
\hline $\begin{array}{l}\text { Alvesson in Svenings- } \\
\text { son (2002, po Nelson } \\
\text { 2003, 107) }\end{array}$ & $\begin{array}{l}\text { Pomen kulture je družbeno lepilo (konsenz in kohezija), kompas (usmerjanje) in izmen- } \\
\text { java (koristnost in transkacijski stroški), čustveni regulatorji (izražena čustva), slepila } \\
\text { (slepe pike glede družbene realnosti). }\end{array}$ \\
\hline Schein 2004 & $\begin{array}{l}\text { Korporativna kultura je osnovni vzorec organizacije, kako delovati in reševati probleme, } \\
\text { oblikuje zaposlene, ki so se zmožni prilagoditi okolju in pridružiti članom organizacije. }\end{array}$ \\
\hline Hofstede in Minkov 1991 & \begin{tabular}{l} 
Kultura je kolektivno, mentalno programiranje skupine ljudi v danem okolju. \\
\hline Criveanu 2015, 74
\end{tabular} \\
\hline $\begin{array}{l}\text { V širšem pomenu korporativna kultura opredeljuje spekter vrednot, navodil, pred- } \\
\text { videvanj, odnosov, ki so splošno sprejeti med člani družbe ali organizacije. }\end{array}$ \\
\hline $\begin{array}{l}\text { Luthans, Vogelgesang in } \\
\text { Lester 2006,85 }\end{array}$ & $\begin{array}{l}\text { Organizacijska kultura je zahtevano znanje, potrebno za interpretacijo izkušenj in ustvar- } \\
\text { janje družbenega vedenja. }\end{array}$ \\
\hline $\begin{array}{l}\text { Korporativna kultura organizacije je mehanizem koordinacije individualnih interesov } \\
\text { in ciljev ter prilagajanje teh strateškim ciljem podjetja, obenem pa ustvarjanje skupne- } \\
\text { ga kulturnega prostora, ki vključuje korporativne vrednote, norme in modele korpora- } \\
\text { tivnega vedenja, ki ga sprejemajo vsi zaposleni. }\end{array}$ \\
\hline
\end{tabular}

Szczepańska-Woszczyna 2015,397

Kultura pomembno vodi organizacijo k uspehu, s tem da so vsi člani organizacije polno zavezani stvari.

Cameron in Quinn $(2006,16)$ poudarjata, da je korporativna kultura povezana s pravili, standardi, načini delovanja, ki odsevajo ideologijo vodstva, ki naj bi bila prevladujoča, predvsem pa težila $\mathrm{k}$ stabilnosti sistema. Dobro jo ponazori izrek Tukaj tako delamo. Cameron in $\mathbf{Q u}-$ inn (prav tam) poudarjata enkratnost, neponovljivost, tudi koherentnost in čvrstost korporacijske kulture kot ključnega dejavnika uspeha na trgu, posebej pa izpostavljata pridobitev konkurenčne prednosti zaradi moči, ki je središče razvoja in vodenja edinstvene korporativne kulture. Ta moč po njunem mnenju ustvarja jasnost, urejenost, kontinuiteto, identiteto in pogled $\mathrm{v}$ prihodnost. Korporativna kultura ima enake sestavine kot katerakoli druga organizacijska kultura, torej zgodbe, način mišljenja, vrednote, identiteto, organiziranost, pripadnost in standarde itd., ki določajo, 
kako zaposleni določajo sami sebe, kako se določa organizacija in kako v organizaciji razumejo posel, ki ga opravljajo. Pomembno pa je, da so organizacijska ravnanja skladna s potrebami kupcev. Korporativna kultura je kot motor, ki poganja organizacijo, jo predstavlja v okolju in omogoča potencialnim kupcem, da jo prepoznajo kot tistega, ki bo najbolje zadovoljil posameznikove (kupčeve) potrebe.

Različni avtorji, ki opredeljujejo organizacijsko ali pa korporatvno kulturo, so navedeni v preglednici. Bistveno je morda dejstvo, da korporativno kulturo razumemo kot vrsto organizacijske kulture, ki ima posebnosti in se po njih loči od drugih vrst organizacijske kulture, denimo adhokracijo, kulturo klana ipd. (glej Cameron in Quinn 2006).

To pomeni, da je vir korporativne kulture vodstvo, ki oblikuje načine komuniciranja $\mathrm{z}$ delavci in skozi komunikacijo prenaša identiteto, kot si jo je zamislilo vodstvo, na zaposlene. Gre torej za oblikovanje načinov dela, vzorcev dela in delovanja, torej identiteto, ki je snovana na tem, kaj podjetje oziroma vodstvo hoče biti in kaj hoče postati (Hatch in Schultz 2003). Ko je to usklajeno, se pojavi povezava med notranjo dimenzijo (identiteto) in zunanjo komunikacijo, ki krepi zasnovo znamke.

Kot vidimo, različni avtorji izpostavljajo pomen organizacijske kulture in njen vpliv na poslovanje podjetja. Organizacijska kultura komunicira svoje vrednote in načine delovanja ne le navznoter, temveč prek identitete in zgodb tudi navzven. Je celostna. Prevzema vse člane organizacije, njihovo delovanje, od vrha navzdol in obrnjeno. Je mehanizem za koordinacijo individualnih interesov in ciljev s strateškimi cilji podjetja in je pomembno strateško orodje, ki kaže zaposlenim pot $\mathrm{k}$ ciljem podjetja (Schultz in de Chernatony 2002; Gaisina idr. 2015).

\section{Kultura kotoblikovalska kategorija}

$\mathrm{V}$ minulem stoletju sta se vloga in pomen oblikovanja postopno razvijala pod vplivom družbenih in ekonomskih sprememb. S prehodom od klasične fordistične proizvodnje $\mathrm{v}$ postindustrijsko sta se spremenila vloga in pomen oblikovanja. $Z$ gospodarsko rastjo in množično potrošnjo $v$ obdobju po drugi svetovni vojni sta se povečala vloga in pomen dejavnosti, ki so potrošnjo spodbujale. $V$ ta segment sodijo oglaševanje, trženje, znamčenje in oblikovanje. Pri oblikovanju namreč ne gre le za oblikovanje samih izdelkov, temveč tudi za trženje, oglaševanje in oblikovanje embalaže pa tudi za vse procese in postopke, povezane s tem. Če hočemo razumeti povezave med kulturo, oblikovanjem in znamčenjem, po-

Angleški izraz, bolj znan v slovenskem prostoru je branding. 
tem moramo najprej razumeti oblikovanje, vlogo oblikovanja in njegov zgodovinski razvoj, kulturo in potrošništvo ter znamčenje. Do »težav« prihaja v izhodišču ravno zaradi napačnega razumevanja oblikovanja, ki je pogosto zreducirano zgolj na oblikovanje predmetov in podob.

Ker je kultura del oblikovanja in z njim povezana, so tudi oblikovalci zasnovali svoje definicije organizacijske kulture, ki so sorodne temeljnim definicijam »klasikov« (npr. Schein 2004; Hofstede in Minkov I991; Cameron in Quinn 2006) organizacijske kulture, dajejo pa svoj specifični poudarek in povezave. Tako Buchanan (1998) opozori na nevarnost redukcije kulture. Kultura ne sme biti izenačena z ideologijo. Kompleksnost kulture tvori procesni vidik, ki utemelji kulturo kot tisto, ki kultivira, hkrati pa kot aktivnost, proces nenehnega spreminjanja, kot delanje ali delovanje.

Kultura pomeni kultiviranje in vrednote skupnosti. Kultiviranje je proces, ki se odraža v določenih stilih in obnašanju, ki naj bi imeli določeno vrednost. Kultura kot način življenja skupnosti, kot statična kategorija, v kateri so zajete strukture vsakdanjega življenja, načini bivanja, vedenjski vzorci.

Materializacija idej človekovega življenja so predmeti, ki sami po sebi komunicirajo neposredno in jasno, zaznavamo pa jih s čutili. Naša izkušnja ni le izkušnja prek videza, temveč tudi tehnologije, kumulativnega učinka predstavitve oblikovanja, dojemanja, uporabe, kar omogoča raznolikost interpretacij (Heskett 20I I, 47).

$\mathrm{V}$ postmodernizmu se je $\mathrm{v}$ ospredje postavilo oblikovanje, ki je poudarjalo pomen in ne uporabne vrednosti. To je bilo značilno za tista podjetja $\mathrm{z}$ majhnim dobičkom, ki so izdelkom poskušala dvigniti dodano vrednost. Tak pristop $k$ oblikovanju temelji na redukciji predmeta na podobo in pomen, izgubi pa se celostni vidik (Heskett 20I I). Pred tem smo bili priča predmetom, ki so bili funkcionalni, a brez pomena. Tudi danes je takih podjetij kar nekaj. Izziv za prihodnost je oblikovati funkcionalne izdelke s pomenom.

\section{Modela kulture oblikovanja}

V tujini obstajajo študiji in študijski programi, ki so usmerjeni v preučevanje vizualne in materialne kulture, to pomeni, da so usmerjeni v analizo vizualnih ali materialnih del. Pri nas takšnega študija, razen umetnostne zgodovine, ki se ukvarja $\mathrm{z}$ analizo likovnih del, pravzaprav ni. Z analizo oblikovalskih del se študenti oblikovanja srečajo v času študija na njihovih projektnih kritikah, morda ob posameznih predmetih na študijskih programih arhitekture. Vendar pri tem ni zajet globlji teoretski 
okvir. Nekaj novosti prinaša študijski program dizajn management, ki se izvaja na Fakulteti za dizajn.

Potrebe po študiju kulture oblikovanja so v teoretičnih krogih in svetovalnih krogih. V tujini so se precej ukvarjali s kulturo oblikovanja kot novo zvrstjo, saj študij zgolj vizualne ali materialne kulture ni dovolj. Ker imamo opraviti s kompleksnim okoljem, ker imamo opraviti s človekom in vso njegovo kompleksnostjo, je treba analizirati in preučevati vizualne, tekstovne, materialne in prostorske elemente, pri čemer je treba upoštevati dinamičnost in raznolikost kulture oblikovanja ${ }^{2}$ kot pojma in kot njenega »življenja $\ll$ (Julier 2000).

Potrebo po preučevanju kulture oblikovanja utemeljujejo tudi Vitta in Nelles (1985, 3), Buchanan (1998) ter Julier (2006). Njihov argument je $\mathrm{v}$ dejstvu, da ljudje $\mathrm{z}$ materialnim svetom, $\mathrm{z}$ materialnimi dobrinami, izražamo kulturo v racionalnih kategorijah. Posebno pa je pomembno, da materialne dobrine ustvarjajo, povezujejo in omogočajo posamezniku, da se s svojo kulturo poveže. V nadaljevanju sta predstavljena dva modela kulture oblikovanja, prvega je zasnoval Julier (2014) in ga nadgrajujejo in dopolnjujejo sodobniki, drugega sta zasnovala Desserti in Rizzo (2014).

\section{Kultura oblikovanja po Julierju}

Oba modela sta zanimiva in uveljavljena v akademskem svetu. Oba imata skupno izhodišče v naslednjih elementih: proizvodnja, oblikovanje in potrošnja.

Kultura oblikovanja, »design culture «, je pojem, ki ga je vpeljal Julier (2000). Po njegovem mnenju je raziskovanje zgolj prek vizualne kulture premalo. Vizualna kultura pomeni preučevanje podob. Prav tako je premalo zgolj preučevanje materialne kulture, to je preučevanje predmetov. Le vizualna in materialna kultura skupaj tvorita celoto, torej kulturo oblikovanja.'

$\mathrm{Na}$ spletni strani poda eno redko objavljenih definicij kulture oblikovanja in jo zato navajamo v celoti (Julier b.l.): >Kultura oblikovanja kot akademska disciplina, raziskovanje medsebojnih odnosov med oblikovalskimi izdelki in vsemi njihovimi predstavitvami, delom oblikovalcev, proizvodnje oblikovanja (vključujoč trženje, oglaševanje in distribucijo), mediation in njihovo potrošnjo. Gre torej za formalne značilnosti

Angleški termin Design Culture prevajamo kot kultura oblikovanja, kajti ne govorimo o kulturi oblikovalcev (oblikovalska kultura), temveč o pojmu, ki zajema več ravni (proizvodnja, potrošnja in oblikovanje).

3 Design culture prevajamo kot kulturo oblikovanja. Gre za analizo oblikovalskih izdelkov, odnosa do teh izdelkov in ne za oblikovalsko kulturo, kar bi bila kultura oblikovalcev. 
(kako so izdelki videti), kako so narejeni in kakšni so različni pomeni ter funkcije tega oblikovanja.«

Ta definicija odraža poskus in težnjo, da se kultura oblikovanja razvija kot znanstveno področje, saj praksa prehiteva teoretičen razvoj. Potrebe po raziskovanju tega področja pa so še posebno močno izražene, ker praksa, predvsem oblikovalska podjetja, ustvarja nove prostore, nove vrednote, ${ }^{4}$ nova ravnanja, katerih vpliv na družbo kot celoto še vedno ni proučen.

V oblikovanju se danes iščejo rešitve za kompleksne družbene probleme, na katere že znani načini, metode in vsebine ne ponujajo novih, boljših ali drugačnih rešitev. To ne pomeni, da je oblikovanje »ostalo《 enostavno, kot se je v preteklosti zdelo. Oblikovanje, nekoč vezano na rokodelstvo, je v globalizacijskih procesih postalo kompleksnejše in hkrati pridobilo pomen ter povečalo vpliv na mnogih področjih. Ne gre več le za produktno oblikovanje, gre za področja prostega časa, informacijsko-komunikacijske tehnologije, igre na srečo ipd. Prav tako se je oblikovanje premaknilo izza zidov ozke stroke - oblikovanja in postalo interdisciplinarno in multidisciplinarno. Tako oblikovanje proučujejo ekonomisti, antropologi in sociologi, poseben prostor mu namenjajo filozofi (Salecl 2012).

\section{Model kulture oblikovanja po Julierju}

Julierjev model je ob odsotnosti interdisciplinarnega preučevanja oblikovalske kulture vez med managementom, oblikovanjem in družbenimi vedami. Temelji na treh stebrih: proizvodnja, oblikovalci in potrošnja.

Proizvodnja vključuje materiale, tehnologijo, proizvodne sisteme in distribucijske kanale. Drugi steber so oblikovalci, katerih funkcija je oblikovanje oblike in vsebine na osnovi vrednot. Tretji steber je potrošnja, ki poleg statističnih analiz vsebuje statusne pomene. Ti trije stebri ne nastopajo posamično, ampak so močno povezani in se celo prekrivajo.

4 Velja poudariti, da v arhitekturi in oblikovanju osrednje mesto zavzemajo vrednote, čeprav se o njih na ekspliciten način zelo malo piše in govori. Implicitno pa so vrednote vsebovane v samem arhitekturnem in oblikovalskem snovanju. Kjer se sprašujemo, ali so materiali, ki jih uporabljamo, trajnostni in okolju prijazni, kako bo družba, skupina, posameznik živel čez 20 let. Kako se vrednote sedanjega časa odražajo v sedanjem prostoru. Tak primer je Slovenska cesta v Ljubljani, ki je bila prenovljena v skladu s trenutnimi družbenimi vrednotami, ki obsegajo skrb za okolje, čist zrak, ki daje prostor pešcem in kolesarjem. To je v nasprotju s preteklimi vrednotami, ko se je Ljubljana motorizirala in je javni prostor zasedal avtomobil. 


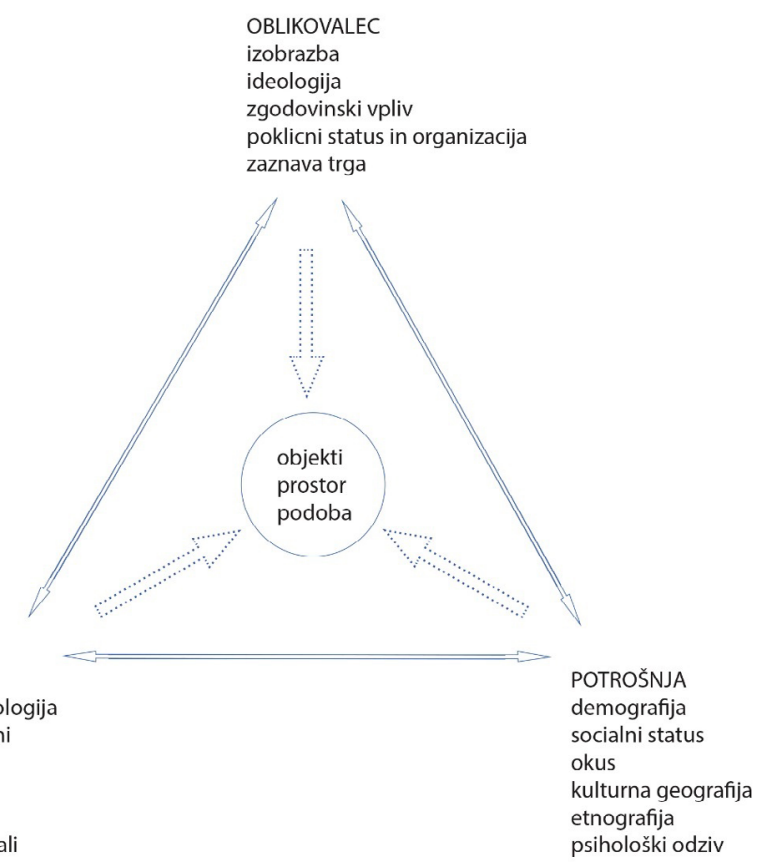

Slika 2: Model kulture oblikovanja

Vir: Julier 2000, 4.

Kot se vidi na sliki, obstajajo med temi stebri nenehen pretok, povezanost in medsebojni vpliv. Hkrati so močni in trdni vsak zase in vplivajo na predmete, prostore, interpretacije in podobe.

Že v modelu kulture oblikovanja vidimo, da v sodobnem svetu oblikovanje ni izolirana dejavnost. Romantične predstave o oblikovalcu kot denimo Leonardu da Vinciju, ki sam snuje novosti in ustvarja v nemogočih razmerah, v realnem svetu ne živijo. Danes so močni timi, saj je znanja tako veliko in je tako kompleksno, da je posameznik preprosto premalo. Zato v oblikovanju in arhitekturi uspevajo močne, raznovrstne, interdisciplinarne skupine. Delček tega se odraža v empiričnem delu te knjige.

\section{Proizvodnja}

V tem poglavju bi poudarili opredelitev oblikovanja kot $\gg$ oblikovanja pod linijo « in »oblikovanja nad linijo «. Nad linijo je del, ki je viden, ki komunicira s potrošnikom. Pod linijo je nevidni, tehnološki del, ki je potrošniku skrit. Običajno nevidni del umestimo med tehnologijo in inova- 
cije. Kot to vidi Julier, sta procesa povezana. Tako postane oblikovanje v organizaciji enoten proces.

Nad linijo je proces, kamor sodijo oglaševanje, znamčenje, oblikovanje embalaže. Pod linijo pa so procesi, ki vključujejo razvoj izdelka, pripravo orodij, tržne raziskave in interpretacijo. Gre za to, da so dandanes ti procesi zbližani oziroma učinkovito sodelujejo. K temu približevanju je pripomogel razvoj načina proizvodnje »Just in time«.' Tako lahko podjetja hitreje in ceneje odgovorijo na nove funkcionalne ali estetske potrebe. To se najbolje vidi na primeru snovanja rešitev za kuhinjsko opremo. Kar ustvari oblikovalec na ekranu, bo naročnik dobil. Od oblikovalca pa je odvisno, ali bo kuhinjsko opremo tudi prodal. Tako se oblikovalci približujejo trženju, s tem pa tudi kulturi potrošnje.

\section{Potrošnja}

Ko govorimo o potrošnji, ne gre izpustiti ekonomskega vidika (Brewer in Porter 2013), ki z različnimi metodami analizira potrošnjo ter določa indekse, kot je denimo BDP. S sociološkega vidika obsega potrošnja širok set kulturnih in ideoloških sistemov (Warde 2005 in 2014), s psihološkega vidika pa je potrošnja povezana s potrebami posameznika, lahko tudi z njegovmi boleznimi (Pham 2013). Potrošništvo je pojem, ki ga povezujemo $\mathrm{z}$ vedenjem odjemalcev, potrošnikov in naravnanostjo družbe, ki spodbuja določene oblike vedenja skupin in posameznikov. »Oblikovalski pogled pa odraža potrošniško kulturo skozi vrednote in celotno podporno strukturo, ki omogoča potrošnjo.« (Julier 2014, 48). Julier (prav tam) ponudi definicijo potrošniške kulture, ki jo veže na potrošnjo. Zanj je potrošnja kulturni in menjalni proces, kjer se izmenjujejo identitete, znaki, simboli, stili življenja in viri, ki so posamezniku dosegljivi. Jedro vseh menjalnih odnosov je, da ni več vprašanje biti, ampak vprašanje imeti. Imeti pa je pogojeno zgolj s kupno močjo, sicer je vse mogoče imeti. Jedro potrošniške kulture je hlepenje po posedovanju, po »jaz imeti«, kjer je v centru $\gg j a z \ll$, torej individualizem, ki naj bi se svobodno odločal. Imeti ne postane $\gg$ biti $\ll$, ker je potreba po nenehno novem $\gg$ imeti $\ll$, da lahko »biti« obstaja. In to je ključna težava potrošništva, hkrati pa tudi priložnost za oblikovalce, da imeti dobi drugačen pomen. Imeti se izkazuje skozi znake, ti znaki pa so postali vrednota.

To je način proizvodnje, ki odraža razpršenost, posebno dereguliranost in tudi neodvisnost. Je odmik od fordizma in hkrati ohranja nekatere njegove značilnosti. 
Sodobna ekonomija, trgovina in politika vodijo sistem $\gg$ znakvrednota «, kako so stvari videti, in določajo, kako je videz interpretiran (Julier 2014).

$\mathrm{V}$ tem lahko vidimo prepletenost proizvodnje, potrošnje in oblikovanja. Morda lahko to poimenujemo kot tok (flux), nenehen pretok med dimenzijami, lahko to opišemo tudi kot trke. Različni avtorji opozarjajo na odločitve potrošnikov, ki so tako racionalne kot intuitivne oziroma emocionalne in utemeljene na »vrednosti za denar « (Salecl 20ro). Vrsta politik kroji potrošništvo, potrošnjo. Kar nekaj šol je usmerjalo teoretična razmišljanja o potrošnji, oblikovanju in potrošništvu, nekatere teorije so kritične, druge pa naklonjene potrošništvu in potrošnji.

Preglednica 3: Kritične teorije o potrošništvu

\begin{tabular}{|c|c|c|}
\hline Avtor(ji) & Obdobje & Koncept \\
\hline Frankfurtska šola & $1920-1960$ & $\begin{array}{l}\text { Oblikovanje in ustvarjalnost v proizvodnji kul- } \\
\text { turnih izdelkov je koordinirana, logična in pre- } \\
\text { računana aktivnost. }\end{array}$ \\
\hline Galbraith & 1967 & $\begin{array}{l}\text { Za preživetje mora kapitalizem »preveč proizva- } \\
\text { jati } \text { glede na potrošnjo, zato morajo biti potrebe } \\
\text { ustvarjene. Pojavi se termin »lažne potrebe «. }\end{array}$ \\
\hline Adorno in Horkheimer & 1979 & $\begin{array}{l}\text { Uporabita izraz »kulturna industrija «, da poudar- } \\
\text { ita podobnosti med popularno zabavo in množič- } \\
\text { no proizvodnjo. }\end{array}$ \\
\hline Carr in Fusi & I98I & $\begin{array}{l}\text { Množično potrošnjo popularne zabave in dobrin } \\
\text { imenujeta »kultura invazije «. }\end{array}$ \\
\hline
\end{tabular}

Skupno tem avtorjem je, da so kritični do sodobnega potrošništva. To manipulira s potrebami potrošnikov in ustvarja lažni občutek pomembnosti in moči v odločanju in izbiranju. Saleclova (20ro) je tudi kritična do sodobnih teorij izbire. Resda ustvarja množica možnosti vtis, da se samostojno in svobodno odločamo, $v$ resnici pa smo omejeni ne le $s$ kupno močjo, ampak tudi objektivnimi in subjektivnimi možnostmi, ki predstavljajo naš okvir odločanja. Potrošnik je pogosto predstavljen, kot so sicer predstavljeni podjetniki - prodorni, nenehno iščejo, hitri, odzivni, uspešni na trgu možnosti. $V$ resnici je potrošnik kot tudi podjetnik na neki način ves čas voden.

Kot nasprotje kritiki potrošništva so se pojavili tudi bolj pozitivni pogledi na potrošništvo, kjer naj bi imeli potrošniki vpliv na izdelek. 
Ti avtorji ustvarjajo občutek skoraj naivnega, pozitivnega pogleda na potrošništvo, kjer je potrošnik kralj, ki je svoboden in je poudarjena njegova individualnost.

Preglednica 4: Potrošnja

\begin{tabular}{lcl}
\multicolumn{1}{c}{ Avtor } & Leto & \multicolumn{1}{c}{ Koncept } \\
Hebdige & 1979 & $\begin{array}{l}\text { Bricolage; potrošniki skušajo z brikolažem in naredi sam asemblažem do- } \\
\text { dati osebni pečat. }\end{array}$ \\
\hline Miller & 1987 & $\begin{array}{l}\text { Potrošnja kot odtujitev; izdelki so v osnovi odtujitveni, potrošnik nima } \\
\text { družbenega odnosa s proizvajalci. Zato z razodtujitvijo skuša prilagoditi. }\end{array}$ \\
\hline Fiske in De Certeau & 1989,1984 & Potrošnja kot vsakodnevna kreativna dejavnost. \\
\hline
\end{tabular}

Druga avtorja, ki sta pomembna z vidika preučevanja potrošnje, sta Veblen (2007) ter Bourdieu in Nice (1980). Raziskovali so, kako je kultura potrošnje povezna $\mathrm{z}$ razlikovanjem in identiteto, pri čemer zavzamejo dobrine simbolično vlogo. Te razlike, ki jih potrošniki ustvarijo, so njihov kulturni kapital.

Od časa, ko je Julierjeva teorija nastala, lahko opažamo porast uspeha zagonskih podjetij na platformah za množično financiranje, kot je kickstarter. Posamezniki se izpostavijo ne glede na uspeh in končni izid. Zdi se celo, da gre za proces in prikaz, kot pa za dejansko nov izdelek. Morda kickstarter spominja na vračanje rokodelstva, ko je v izložbi čevljarske delavnice sedel mojster in izdeloval čevelj. Končnega izdelka marsikdo ni videl. So pa vsi mimoidoči bili del procesa. Ta pojav Mc Guirk (20I I), kurator in kritik oblikovanja, opisuje kot fetišizem rokodelstva (ang. Craft Fetishism). Pri tem rokodelstvo povezuje z avtentičnostjo, verodostojnostjo, ki se zoperstavlja množičnim korporativnim izdelkom. Gre za preskok, kjer je oblikovalec obenem izdelovalec, rokodelec. Ta princip je uporabil tudi Gucci.

\section{Oblikovanje}

Kot smo že omenili je oblikovanje prisotno povsod, saj ne gre zgolj za oblikovanje predmetov, temveč tudi procesov in vsega okoli nas. Naloga oblikovanja v podjetjih je, da vgradijo kulturno vsebino v razmerja med človekom in tehnologijo.

Proizvodnjo in potrošnjo povezuje oblikovalec. Gardner in Sheppard (1989, po Julier 2014, 59) pravita, da je urejanje odnosa med proizvodnjo, izdelkom in potrošnikom glavna naloga oblikovalcev. 


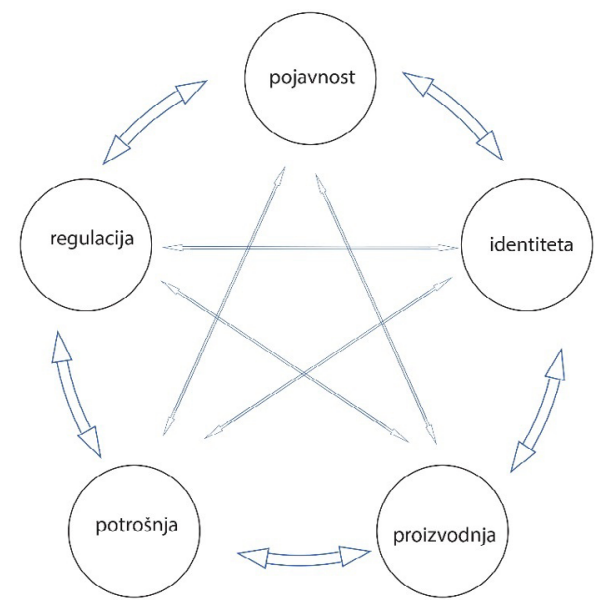

Slika 3: Povezanost med proizvodnjo, potrošnjo, identiteto, pojavnostjo in regulacijo

Vir: Du Gay 1997.

Ta tok kulture odpira vprašanja o trikotniku Julierjevih stebrov. Vprašanje je, ali bi morali biti kultura in identiteta, torej človek, osrednja elementa trikotnika.

\section{Vloga oblikovalcev}

Vloga oblikovalcev se je v času in v skladu z družbenimi - proizvodnimi razmerami spreminjala.

Danes je oblikovanje v podjetjih različno organizirano, od najemanja zunanjih agencij do notranjih oblikovalskih oddelkov, ki obenem delujejo na trgu. Tako so oblikovalci bolj ali manj vpleteni v proces nastajanja izdelka in v samo organizacijo. Vsaka od teh oblik ima svoje prednosti in slabosti. Če podjetja oblikovalce najamejo iz agencije, je prisotna večja odprtost, lahko dobijo sveže ideje, vendar pa so premalo vpeti v proizvodnjo in kulturo podjetja. Oblikovanje ustvarja izkušnje, zato morajo oblikovalci aktivno delovati v smeri razvoja oblikovalske kulture (Frascara 200I), predvsem pa presegati raven izdelkov in storitev. V bistvu jih avtor vidi kot vizionarje s pogledom $\mathrm{v}$ prihodnost, kot oblikovalce kulture in ne izdelkov. Posebno vprašanje seveda je, kako to doseči s sedanjim sistemom izobraževanja. Oblikovalec je uspešen, ko sledi trendom, hkrati pa ga učijo, kako je treba biti drugačen, ker bo le tako uspešen na trgu. Sledilci trendom so lahko tako celo uspešnejši kot tisti, ki trende oblikujejo (trend-setterji). Oblikovanje tako ne spreminja sveta, pač pa je orodje v ustvarjanju različnosti, fragmentacije, razhajanja med posameznikom 
in kulturo, predvsem pa ni več metafora za tehnologijo in jezik, ki postajata dva ločena svetova, namesto dva svetova v enem. Še več, gre za družbo spektakla, kot jo poimenuje Debord (2008).

Kritike oblikovanja torej kažejo oblikovanje kot orodje za ustvarjanje družbe spektakla, kot ji pravi Debord (2008). Pri tem se pojavi vprašanje, ali je takšno »spektakularno « oblikovanje posledica slabega razumevanje oblikovanja ali je morda namerno nerazumevanje pripeljalo do tega. Ob prebiranju literature s področja dizajn managementa je videti, da imajo avtorji globok uvid $\mathrm{v}$ opredelitev in pomen oblikovanja, vendar je potem praktična izpeljava nedodelana in površna. Findeli (200I) pravi, da »mora biti oblikovanje ne poklic, temveč način « delovanja. 


\section{Identiteta}

Trije vidiki identitete so pomembni, in sicer korporativni in individualni vidik ter znamčenje. V nadaljevanju jih obravnavamo kot korporativno (organizacijsko) identiteto in identiteto zaposlenih. Oba vidika sta povezana, saj naj bi korporativna identiteta tvorila osnovo za identiteto zaposlenih. Znamčenje pa je identiteta potrošnika z organizacijo. Tako se povežejo posamezniki in podjetje ter gradijo pripadnost, ki je ustvarjena na čustveni in razumski osnovi.

\section{Korporativna identiteta}

Korporativno identiteto ustvarjajo zaposleni v podjetju. Sestoji iz tega, kaj zaposleni mislijo, čutijo, kako se vidijo, zaznavajo o sebi kot o organizaciji. Korporativna identiteta odgovori na temeljno vprašanje, kdo smo, kaj delamo, kam želimo in kako bomo tja prišli (Schultz 2000; Olins 2002). Identiteto lahko delimo na mehko, denimo podoba podjetja in komuniciranje, in čvrsto, denimo filozofija organizacije, kultura (Staub, Kaynak in Gok 2016). Identiteto lahko razumemo kot vrednoto, kot vidni artefakt ali kot strategijo (Schultz, Hatch in Mogens Holten 2000). Identiteta je lahko monolitna (eno ime), vgrajena (kombinacija s splošnim imenom) in znamčena. Poudarek v tej tipologiji je na identiteti, ki jo podjetje uporablja za trženje (Schultz, Hatch in Mogens Holten 2000). Če nas zanima identiteta, kot kdo si, kaj delaš, to vključuje poleg podjetja in znamke še zaposlene.

Podjetje, ki nima ali ne more izraziti identitete (Baccarani in Golinelli 20I5), ki nima jasno izraženih pričakovanj in prepričanj, ki jih imajo 
zunanji in notranji udeleženci do organizacije (Hsu 2005), in nima specifičnih setov pravil in lastnosti (Hsu in Hannan 2005), na trgu ne bo moglo preživeti.

Preglednica 5: Korporativna identiteta

\begin{tabular}{ll}
$\begin{array}{l}\text { Schultz in de Chernatony } \\
\text { 2002; Balmer in Gray 2003 }\end{array}$ & $\begin{array}{l}\text { Ko govorimo o identiteti, govorimo o setu korporativnih vrednot, viziji, prepričanjih in } \\
\text { oblikovanju, ki so vgrajeni v korporativno znamko z verbalnimi in vizualnimi znaki, ki } \\
\text { nakazujejo določeno poslovno vedenje }\end{array}$ \\
\hline $\begin{array}{l}\text { Monfort, Sebastián in } \\
\text { López 2015, 31 }\end{array}$ & $\begin{array}{l}\text { Korporativno identiteto predstavljajo različni simboli, logotipi, barve, vonjave, glasba, } \\
\text { ki spodbuja spomin na obljube identitete znamke. }\end{array}$ \\
\hline $\begin{array}{l}\text { Monfort, Sebastián in } \\
\text { López 20I5 }\end{array}$ & Na kratko, identiteta je to, kar podjetje govori o sebi. \\
\hline $\begin{array}{ll}\text { Albert in Whetten 1985 } \\
\text { Corley 2004 po Ashforth, } \\
\text { Rogers in Corley 2010 }\end{array}$ & $\begin{array}{l}\text { Identiteta opisuje bistvo nečesa (kdo sem kot posameznik, kdo smo kot skupnost) ne } \\
\text { glede na to, ali odraža objektivno realnost ali subjektivni konstrukt. }\end{array}$ \\
\hline
\end{tabular}

Kot vidimo, je vsem opredelitvam skupno, da so temelj obstoja organizacije, podjetja, identitete, ki morajo biti jasno opredeljene in tako usmerjati vse udeležence. Brez identitete podjetje ne le ne more napredovati, temveč ne more niti obstajati.

\section{Identiteta zaposlenih}

Preglednica 6: Ključni koncepti poklicne identitete

\begin{tabular}{|c|c|}
\hline Avtor & Koncept \\
\hline Ibarra idr. (1999) & $\begin{array}{l}\text { Poklicna identiteta je posameznikova samoopredelitev za člana poklicne- } \\
\text { ga združenja. }\end{array}$ \\
\hline Ashforth, Rogers in Corley $(2010,6)$ & $\begin{array}{l}\text { Identiteta zagotavlja definicijo sebe v vlogi in vključuje cilje, vrednote, pre- } \\
\text { pričanja, norme, stile sodelovanja, časovne opredelitve, ki so tipično pov- } \\
\text { ezani z vlogo. }\end{array}$ \\
\hline Sherwood (1965) & $\begin{array}{l}\text { Samoidentiteta je definirana kot celota samoatributov osebe v danem tre- } \\
\text { nutku v času. }\end{array}$ \\
\hline Sherwood (1965) & Samoidentiteta je določena z odnosi z drugimi. \\
\hline $\begin{array}{l}\text { Pratt, Rockmann in Kaufmann } \\
(2006,235)\end{array}$ & Identifikacija vključuje spremembo identitete. \\
\hline Balmer in Gray (2003) & $\begin{array}{l}\text { Ko govorimo o korporativni identiteti, se nanašamo na set korporativnih } \\
\text { vrednot, vizijo, verovanje in oblikovanje. }\end{array}$ \\
\hline
\end{tabular}

Prav tako kot je pomembna korporativna identiteta, je pomembna tudi identiteta zaposlenih oziroma individualna/poklicna identiteta. Iz 
opredelitev poklicne identitete in identitete organizacije vidimo, da se ti elementi močno prepletajo in soobstajajo. Pomembna naloga vodstva je, da se identitete lahko razvijajo in sobivajo. Za podjetja in njihov obstanek postaja vedno bolj pomembna identiteta, pri čemer ne gre le za tržno usmeritev in nagovor kupcev in potrošnikov, temveč postaja identiteta orodje za krepitev pripadnosti podjetju. Identiteto vidijo kot strateško orodje in mehanizem za koordinacijo individualnih interesov in ciljev. $\mathrm{V}$ preglednici 6 so nanizani nekateri ključni koncepti, povezani s poklicno identiteto.

Pri preučevanju povezanosti poklicne in korporativne identitete velja biti pozoren na dva koncepta, identiteta $z$ organizacijo in identiteta organizacije. Za tiste, ki se ukvarjajo z identiteto z organizacijo, gre za to, v kolikšni meri se posameznik identificira z lastnostmi, ki so obenem lastnosti organizacije, pri čemer sta pomembna ponos in vpletenost.

Identiteta organizacije pa je pomembna osnova, s čim naj se zaposleni identificirajo.

\section{Zakaj je identiteta pomembna}

Podatki kažejo, da vedno večji delež vrednosti podjetij predstavljajo neotipljiva sredstva, kot so znamka, družbena odgovornost, kultura. Identiteta je element kulture in kot taka je lahko orodje za upravljanje korporativne kulture, saj opisuje bistvo organizacije, govori o razlikovalnih lastnostih.

Korporativna kultura mora upoštevati identiteto in način, $s$ katerim komunicira z delavci (Hatch in Schultz 2003).

Kot lahko vidimo, je ob kratki dobi novih izdelkov, globalnem trgu, novih akterjih in tržnih nišah identiteta zelo pomembna. Pomembno je, kako podjetje komunicira $\mathrm{z}$ javnostmi navzven in kako nagovarja lastne zaposlene, partnerje. Gre za celostno, holistično videnje in zaznavanje identitete, kjer je podjetje celota in se kot taka tudi predstavlja.

\section{Znamčenje}

Znamčenje ali angleško branding je pojem, ki se vedno bolj uporablja v menedžerskem diskurzu. Pomemben je za predstavitev podjetja na trgu,

\footnotetext{
Quinn in Cameron govorita o organizacijski kulturi in tudi o subkulturah, ki se pojavijo v različnih oddelkih. Ti oddelki pa morajo biti kljub svojim različnostim povezani v celoto in biti del »glavne « kulture podjetja. Ker gre v nalogi za ugotavljanje kulture oblikovanja v različnih podjetjih, se v tej točki ne bomo podrobneje spuščali v vprašanje subkultur. Kulturo oblikovanja podjetja bomo proučevali z vidika glavne kulture.
} 
saj je znamka globoko občutenje človeka o izdelku. Potrošniška izbira je večja, zato se lahko potrošniki odločajo o lepoti, enostavnosti, funkcionalnosti in pripadnosti njihovi znamki.

Znamčenje se uporablja predvsem $\mathrm{v}$ kontekstu oglaševanja in komuniciranja s potrošniki (Harris in de Chernatony 200I, 44I). Del znamčenja so tudi zaposleni, ki so posredniki med znamkinim zunanjim in notranjim okoljem. Zaposleni lahko vplivajo na potrošnikovo zaznavo znamke in organizacije. Razlikujeta med linijskim in korporativnim brandingom in pravita, da korporativni potrebuje več pozornosti na organizacijo (Harris in de Chernatony 200I).

Celostni vidik znamčenja temelji na ideji, da znamka in podjetja nista zaprta sistema, ampak odprta in delujeta prek vseh komunikacijskih kanalov. Ti kanali niso le oglaševanje, temveč tudi neposredni odnosi zaposlenih z različnimi deležniki (Schultz in de Chernatony 2002, I05).

Podjetja obravnavajo znamčenje kot aktivnost, ki se izvaja na vseh ravneh organizacije. Tako znamčenje ni le del marketinškega komuniciranja, temveč postaja strateška usmeritev. $S$ tem zagotavlja organizaciji strateški okvir in konkurenčno prednost (Schultz in de Chernatony 2002, 105). S tem podjetje izraža, kdo je in za čim stoji, se pravi, sporoča svojo identiteto in kulturo (Schultz in de Chernatony 2002, 105).

Identiteta torej pomeni to, kar podjetje govori o sebi (Monfort, Sebastián in López 2015, 3).

Korporativna identiteta in znamka sta elementa diferenciacije na trgu pri potrošnikih in zaposlenih, ki so hkrati potrošniki v zunanjem svetu. Monfort, Sebastián in López (2015) poudarjajo, da so zadovoljni zaposleni v bistvu komunikacijski kanali, ki sporočajo v okolje vrednote podjetja in $s$ tem spreminjajo korporativno identiteto $\mathrm{v}$ pozitivno zunanjo podobo.

Prav zaradi te vrednosti znamke in korporativne identitete kot nematerialne vrednosti, ki mora biti vgrajena $\mathrm{v}$ strategijo podjetja ter korporativne odgovornosti, je podjetje na trgu prepoznano in ustvarja konkurenčno prednost. Znamke so nosilci vrednot, pomenov in sporočil vrednot, pomenov ter sporočil identitet. Zato mora biti korporativna identiteta kot del kulture usklajena z znamko.

\section{Kultura oblikovanja po Dessertiju in Rizzu}

Desserti in Rizzo (2014) predstavita model kulture oblikovanja kot procesa. To pomeni, da če je izdelek dokaz kulture podjetja, potem moramo sočasno opazovati, kako nov izdelek povzroči spremembo v kulturi. To- 
rej sproži kultura oblikovanja spremembe v celotnem podjetju med razvojem novih produktov.

Desserti in Rizzo (2014) opredelita kulturo oblikovanja (morda bi na tem mestu lahko govorili o oblikovalski kulturi zaradi razlike, kot smo jo že opredelili) kot sistem znanj, kompetenc in veščin, ki delujejo v danem kontekstu. Pri tem gre za mišljenje oblikovanja kot celostni vidik. Nasprotje temu je menedžerski model, saj to pomeni model od zgoraj navzdol (top down). Oblikovalsko mišljenje je lahko učinkovito le, če ni ločeno od kulture, ampak je njen sestavni del, organizacija pa mora razviti od spodaj navzgor (bottom up) model, da bo uspešna. Vsako podjetje mora imeti lastno oblikovalsko kulturo (Desserti in Rizzo 20I4). V jedru tega modela so projekti in inovacije.

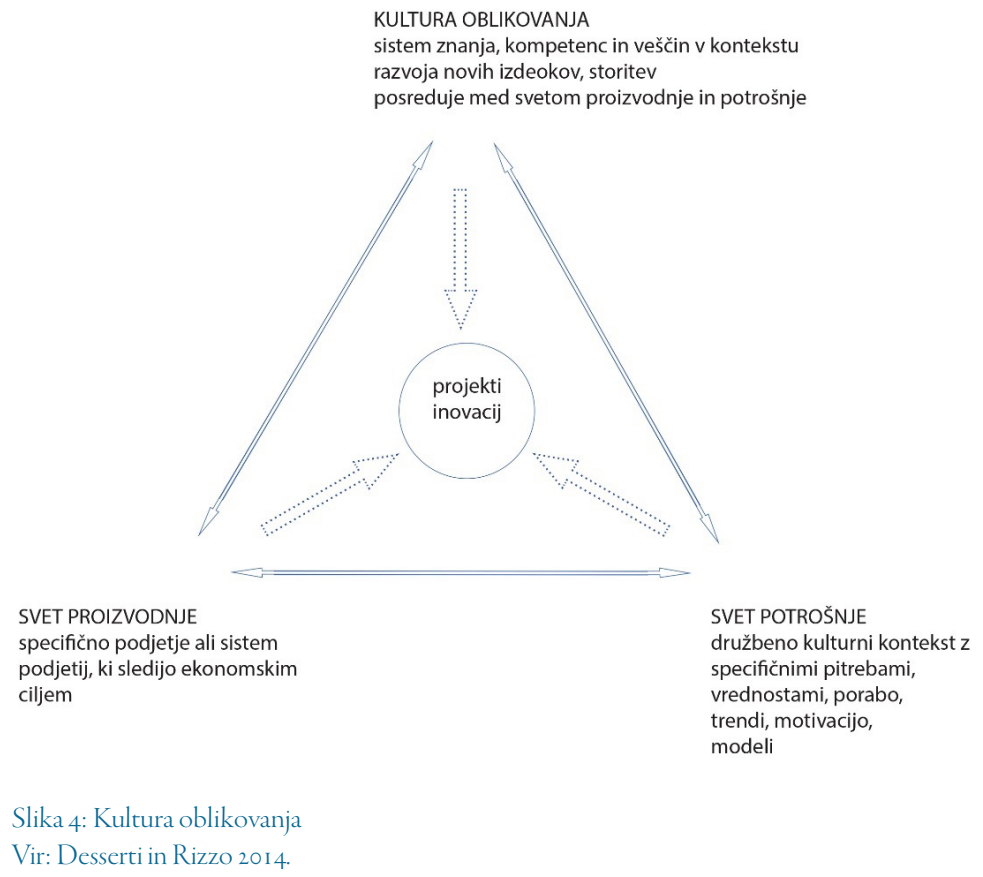

Modela se ločita predvsem po tem, kaj poganja tok med dimenzijami oziroma stebri, ki so sicer zelo sorodni in imajo podobna teoretska izhodišča. Razlikujejo se ravno po gonilni sili. Deserti in Rizzo kot gonilno silo vidita inovacije, Julier (2014) pa meni, da so to objekti, prostori in podobe. Če sledimo definiciji oblikovanja kot procesu, potem lahko izpeljemo, da procesni naravnanosti bolj sledi opredelitev Desertija in Rizza (2014), medtem ko je opredelitev predmetov, prostorov in podob bolj statična. 
Dizajnerska kultura in nagrada za oblikovalske dosežke

Če vzamemo definicijo, da je oblikovanje osnovna človeška dejavnost, ki prevzema vse vidike življenja, in upoštevamo, da kulturne spremembe vplivajo na oblikovanje, bi lahko rekli, da je v središču trikotnika sprememba z nosilcem človekom. 


\section{Oblikovanje v organizacijah}

Če smo v poglavju dva govorili o modelu preučevanja oblikovanja kot odnosu do potrošnje in proizvodnje, bomo $\mathrm{v}$ tem poglavju opredelili samo jedro oblikovanja. Tako bomo predstavili oblikovalski in menedžerski vidik, oba se prepletata v organizacijah, in podali opredelitve oblikovanja s poudarkom na raznolikosti teh definicij.

\section{Oblikovalski vidik}

Enostavna in ključna definicija, ki opredeljuje oblikovanje, je Heskettova (20II, IO), ki pravi, da je oblikovanje bistvo človekovega bivanja in kot tako temeljna določilnica kakovosti človekovega življenja. Oblikovanje je povsod okoli nas.

Skupina pogledov na oblikovanje je predstavljena v preglednici 7.

Preglednica 7: Skupine definicij oblikovanja, ki so jih razvili oblikovalci

\begin{tabular}{ll}
\multicolumn{1}{c}{ Avtor } & \multicolumn{1}{c}{ Koncept } \\
\hline Heskett 20II & Oblikovanje kot temeljna človeška aktivnost in bistvo človeka. \\
\hline Buchanan 1998 & Oblikovanje kot orodje komuniciranja. \\
\hline Kralj 1963 & Oblikovanje kot odsev družbe. \\
\hline
\end{tabular}

V nadaljevanju je izpostavljenih nekaj ključnih opredelitev oblikovalcev in teoretikov oblikovanja. Pomembne so za nazoren prikaz, kaj vse oblikovanje obsega in v kakšni meri prežema naša življenja na vseh ravneh družbe. 
Heskett (20I I) poudarja, da je oblikovanje temeljna značilnost življenja, in skupaj z jezikom opredeljuje »človeka«, hkrati pa je naš vsakdanjik. Meni, da če pogledamo bistvo oblikovanja, ki je brez navlake, dodatkov in nepotrebnih opisov, je oblikovanje človekova zmožnost snovanja okolja, ki najbolje ustreza potrebam človeka, daje smisel življenju in ustvarja okolje, ki ga v naravnem kontekstu ne najdemo.

Poleg te dimenzije »človeškosti« drugi teoretiki poudarjajo tudi oblikovanje kot komunikacijsko orodje v popularni kulturi (Buchanan 1998, 10), oblikovanje kot kulturni, gospodarski in sociološki problem vse družbe in ne le njegovo tržno dimenzijo ali pa kot zasebno dimenzijo oblikovalca (Kralj 1963, v Predan in Šubic 201 I). Oblikovanje bo vrednoteno in ocenjeno skozi dokumente materialne kulture $\mathrm{v}$ zgodovinski perspektivi.

Braha in Reich (2003) poudarjata, da terja oblikovanje kot generični proces nenehno spreminjanje ciljev in/ali zahtev in specifikacij, zato ker so se pojavile nove informacije. To je nenehni proces, katerega končni cilj je predlagana oblikovalska rešitev, $\mathrm{v}$ kateri ni trenj med prostori.

Pri teh opredelitvah vidimo, da doživljajo avtorji oblikovanje kot temelj posameznika in družbe. Opredeljujejo ga kot zasebno in javno zadevo, kot bistvo človekovega bivanja in kot pomembno komunikacijsko orodje v sodobni družbi. To pa pomeni, da bi lahko postavili trditev, da »biti《 ni $\gg$ biti «, če ni tudi oblikovati, torej $\gg$ biti = oblikovati $\ll$.

Tudi opredelitve s področja managementa oblikovanja so podobne opredelitve, kjer pa je večji poudarek na ekonomskem in organizacijskem vidiku oblikovanja oziroma tem, kaj tudi tehnološke spremembe prinesejo k razumevanju oblikovanja. Avtorica Borja de Mozota (2003, 2) ponudi več definicij oblikovanja:

Oblikovanje je osrednji dejavnik inovativne humanizacije tehnologije in kritični dejavnik inovativne humanizacije tehnologije ter ključni dejavnik kulturnih in ekonomskih sprememb.

Oblikovanje je prisotno v vseh oblikah, ljudeh, projektih, izdelkih in storitvah. To je, kot pravi, »Best touch point«, torej stikališče, kjer se pretakajo informacije med oblikovalci in menedžerji o zaznavah organizacije in znamke (prav tam).

$S$ poudarkom na zaznavah organizacije in znamke je oblikovanje orodje za doseganje ciljev organizacije. Redukcija oblikovanja na orodje je lahko $\gg$ nevarna $\ll$, saj lahko pri tem pride do uporabe oblikovanja le kot stilske preobrazbe, pri tem pa manjkajo nekateri ključni elementi oblikovanja. To pomeni, da so lahko na nek način orodje manipulacije, ki slu- 
ži zgolj prekomernemu trošenju in večji proizvodnji, ne nosijo pa globljih sporočil in s tem ne zadovoljijo uporabnika.

Julier $(2000,3)$ govori o oblikovanju kot o strateškem orodju, kar pa še vedno pomeni, da je oblikovanje reducirano na orodje, ki je v funkciji poslovnih rezultatov. Oblikovanje pa je več kot orodje, je način mišljenja, način bivanja, način dojemanja sveta in način delovanja. Oblikovanje je povezano s kulturo, o čemer smo že pisali.

Desserti in Rizzo (2014) opredelita ta dva vidika oblikovanja kot:

- redukcionističen vidik, kjer je oblikovanje ena od veščin, ki poudari izdelek, in

- kulturološki vidik, kjer gre za unikaten sistem kompetenc, znanja in veščin, ki predstavlja inovativne rešitve.

Že iz imen vidimo, da je problem redukcija, poenostavljanje. Oblikovanje je nosilec in sooblikovalec vrednot ter temeljna sestavina kulture. Morda velja izpostaviti, da so znani finski oblikovalci, ki jih laična javnost rada omenja, vendar le redko kdo ob tem pove, da je oblikovanje na Finskem vpeto v njihovo kulturo, je njihova kultura. Morda so zato v skandinavskih državah oblikovalci povezali oblikovanje s trajnostnim razvojem oziroma trajnostnim življenjskim slogom. Bjogvinsson idr. (2012) so zato izpostavili oblikovanje kot pomemben proces, ki bo razvijal in spreminjal okolja, ta pa bodo prispevala k spremembam v življenjskem slogu in potrošništvu.

Nekateri oblikovalci so začeli razvijati vlogo oblikovalca kot vizionarja v družbi, ki ima vpogled v družbene izboljšave prihodnosti in sodeluje s tehnologijo. Ta povezava s tehnologijo in tudi industrijo se kaže od iq. stoletja naprej, ko se je zgodil premik v proizvodnji od obrtniškega k industrijskemu načinu, s tem pa tudi k industrijskemu oblikovanju. Povečala se je potreba po sodelovanju med oblikovalci in izvajalci. Takrat se je izoblikoval Sullivanov koncept »Form Follows function ${ }^{1} \ll$, ki je močno vplival na industrijsko oblikovanje v smislu, da tudi industrijsko oblikovani izdelki nosijo neki pomen, vrednote. Bistvo tega koncepta je poudarek na pomenih in vrednotah, ki jih morajo imeti tudi industrijsko oblikovani izdelki.

Če forma sledi uporabnosti, namenu, funkciji, potem lahko opredelimo uporabnost kot ustreznost glede namembnosti.

Form follows function, pojem, ki se uporablja v oblikovalski stroki in pravi, da oblika sledi funkciji. Prihaja s področja arhitekture in je v oblikovalskih in arhitekturnih krogih splošno sprejeto dejstvo. 
To pomeni, da se oblikovanje ukvarja s tem, kako stvari delujejo, ali ustrezajo. $^{2}$

$S$ tem pa lahko industrijsko oblikovani izdelki postanejo nosilci vrednot in odražajo stanje v družbi. V družbi oziroma človeški kulturi je preurejanje, prerazporejanje, razlikovanje bistvena lastnost. Ker oblikovanje temelji na vrednotah in tudi kultura temelji na vrednotah, to spreminjaje pomeni, da če je kultura nenehno prevpraševanje, preurejanje, je to tudi oblikovanje. Kljub temu obstajajo oblikovalci in teoretiki, denimo Branzi (1986), ki vidijo oblikovanje kot ideologijo in ga želijo na neki način standardizirati in s tem oblikovanje omejiti na podobo.

Prav to standardizacijo kritizira Buchanan (2008), ki meni, da je v standardizaciji vsajena nevarnost redukcije oblikovanja ne samo na slog, ampak tudi na orodje trženja. Če se izgubi sprememba, pluralizem, dinamičnost procesa, potem obstanemo kot potrošniki izpostavljeni tržnim aktivnostim, ki temeljijo na podobah - kot da živimo v simulakrah (Baudrillard i994).

Ne glede na razhajanja je avtorjem skupno, da oblikovanje razumejo kot temeljno človeško dejavnost $\mathrm{z}$ vidnimi rezultati.

Če na vprašanje oblikovanja pogledamo še skozi analizo besede dizajn, potem vidimo v ospredju predvsem razliko, ki se pojavi v angleščini, in sicer design kot oblikovanje, pri čemer se enkrat pojavi oblikovanje kot samostalnik in drugič design kot oblikovati, glagol. V prvem primeru gre za izgotovljene izdelke, storitve, ki so zlasti v vsakodnevnem življenju uporabljene kot del mode in stilov. V drugem primeru, design kot glagol, pa gre za proces oblikovanja, torej za način, kako opredeliti problem in projekt ter kako odgovorno iskati izboljšavo v svetu.

O tem razlikovanju govorita tudi Heskett (201 I) in Julier (1998), ko oblikovanje opisujeta kot »cultura del progetto $\ll$. V jedru kulture del progetto so procesi oblikovanja, izbiranja in odločanja. To pa so procesi, ki jih v managementu najdemo opredeljene kot načrtovanje.

Tobias Frere - Jones (2016) govori o kulturi načrtovanja, katere jedro je nenehno oblikovanje in iskanje oblikovalskih rešitev: »Ko misliš, da je oblikovanje končano, ti je samo zmanjkalo sposobnosti, da bi opazil pomanjkljivosti.«

Ta dvojnost oblikovanja se kaže v razhajanju med posvojenim menedžerskim vidikom, kjer oblikovalci večinoma težijo $\mathrm{k}$ hitremu iskanju re-

2 Pri tem Heskett $(20$ I I, 36) opredeli pomen kot oblikovalski pojem, kot nosilec vrednot, saj oblike pri uporabi prevzamejo vloge, namene, smotre, ki jih je oblikam neka družbena skupnost pripisala. Tako postanejo simboli ali ikone šablonskih navad in običajev. 
šitve in oblikovanje razumejo zgolj kot oblikovanje estetskega izdelka. Oblikovalski vidik pa pomeni celostni vidik $\mathrm{k}$ oblikovanju.

Vloga oblikovanja v organizacijah tako ni več le stiliranje izdelkov, temveč je vloga oblikovalca v osnovi podpirati razvoj novih konceptov in jih narediti dosegljive uporabnikom, sodelavcem. Zato se pojavlja opredelitev oblikovanja kot sodelovalne storitve, ki spodbuja $\mathrm{k}$ iskanju novih rešitev in konceptov.

Ravno zaradi narave dela oblikovanja, ki je v svojem bistvu sorodno managementu, kjer gre za nenehno oblikovanje in preoblikovanje izdelkov, procesov in storitev $\mathrm{z}$ namenom ustvariti nove trge in uspeti na obstoječih, imata oblikovanje in management veliko skupnega. Morda je to razlog, da so menedžerji začeli v iskanju konkurenčnih prednosti sprejemati oblikovanje kot rešitev. Problem, ki še ostaja, pa je, da je oblikovalska stroka še vedno malo (pre)poznana. Oblikovalska stroka se še prepogosto dojema skozi redukcionističen vidik (Buchanan (I998, i I). Prav tako se je zameglil cilj oblikovanja, pravzaprav njegov temeljni namen, to pa je oblikovati izdelke, ki imajo povezovalno vlogo $\mathrm{v}$ družbi, skozi vrednote in $\mathrm{z}$ vrednotami ustvarjati zadovoljstvo ter sporočati, kaj je dobro in uporabno (Buchanan 1998).

Vidimo lahko, da oblikovanje ni le individualni proces, kjer oblikovalec ali skupina oblikovalcev išče rešitev, temveč gre za vpetost $\mathrm{v}$ podjetje in v celotno širše družbeno, navsezadnje naravno okolje. Glede na ekonomsko in okoljsko krizo bo iskanje novih etičnih rešitev in konceptov vedno bolj pomembno. Pri tem ne bo dovolj statičen redukcionističen vidik, temveč celosten in globok pogled na družbo, okolje, kulturo in oblikovanje. Pričakujemo lahko, da bo oblikovanje pomembno pri trajnostni potrošnji, morda še bolj pa pri razvijanju okoljske ozaveščenosti in delovanja za spremembe v ravnanju in odnosu do okoljskih in družbeno-ekonomskih vprašanj.

\section{Menedžerski vidik}

Raziskovanje vpliva oblikovanja na organizacije je dokaj novo in sveže. Delno se je začelo v 9o. letih, ko so nekatere agencije razširile svoje področje delovanja. Prva konferenca, ki je naznanila obsežnejše področje raziskovanja, je leta 2002 organizirana 'Managing as Designing', ki jo je organizirala Weatherhead School of Management. Tu so raziskovali oblikovanje predvsem v sklopu inoviranja. Leta 2004 je sledila konferenca 'Organization Design', ki jo je organizirala Stern School of Busines newyorške univerze. Na teh in tudi poznejših konferencah so spoznali, da lahko pride do organizacijskih sprememb tudi prek oblikovanja in 
da je zato treba oblikovanje raziskati z vseh vidikov. Svetovalne agencije so želele te postopke poenostaviti in skrčiti, ponuditi podjetjem hitre rešitve. Podjetja te proučene, skrčene postopke razumejo kot »znanstveno utemeljene « zaradi nosilcev svetovanja, ki so pogosto »znanstveno « izobraženi, torej imajo neki akademski naziv in s tem kredibilnost.

Skupne točke oblikovanja in managementa so torej načrtovanje, kultura, identiteta in znamčenje (Konečnik-Ruzzier 20II). S tem so se teoretiki managementa veliko ukvarjali. Tako so obsežne študije o organizacijski kulturi, načrtovanju, vodenju projektov, managementu znanja (Gomezelj Omerzelj, Biloslavo in Trnavčevič 20ı) in inovacijah (Likar, Križaj in Fatur 2006). Borja de Mozota (2003) poveže oblikovanje z inovacijami in vidi oblikovanje kot menedžersko orodje, kot proces, ki prežema vse pore organizacije, prav tako pa tudi procese, kot so management idej, management inovacij, management raziskav in razvoja.

Problem je navdušenje nad oblikovanjem in njegovo nekritično vpeljevanje v prakso, kjer je vse lahko oblikovano, tako kot je nekaj časa veljalo, da je vse obvladovano »menedžerirano «. Tako kot smo bili v minulih letih priča nekritičnemu navdušenju nad vsemi principi upravljanja kakovosti, ki so vodili do togosti in neustvarjalnosti, smo zdaj priča nekritičnemu navdušenju nad oblikovanjem. Ne vemo še, kam nas bo to pripeljalo, vsekakor pa je treba vzpostaviti kritičen odnos do nekritično vpeljanih poenostavljenih postopkov, ki so jih hotele svetovalne agencije vpeljati v podjetja in ponuditi takojšnje rešitve. Podjetja so namreč ponudbo svetovalnih agencij pogosto razumela kot znanstveno utemeljeno. Odsotnost raziskav so nadomestile praktične izkušnje, ki so v obliki navodil veljale za kratek čas in za omejene situacije. Najverjetneje bo naloga v prihodnosti najti pravo razmerje med temi elementi in način, kako to voditi. Po našem vedenju empiričnih raziskav o povezanosti oblikovanja in managementa še ni. Nastajajo pa diplomska dela, ki pogosto zajemajo oblikovanje $\mathrm{s}$ strateškega vidika in v sklopu znamčenja. 


\section{Design thinking}

$\mathrm{V}$ tem poglavju bomo predstavili pojma 'design thinking' (oblikovalsko mišljenje) in 'designerly thinking' (mišljenje oblikovanja), kot se pojavljata v strokovni literaturi. Mnogi menijo, da je način mišljenja in dela oblikovalcev ključ do pridobivanja konkurenčne prednosti in ustvarjanja kulture oblikovanja.

\section{Kaj je oblikovalsko mišljenje (design thinking)}

Oblikovalsko mišljenje (design thinking) je pojem, o katerem vedno več slišimo in se uporablja $\mathrm{v}$ dizajn management svetovalni literaturi pa tudi v znanstvenih člankih, kjer ta način mišljenja proučujejo.

Design thinking je na splošno opredeljen kot analitičen in kreativen proces, kjer oblikovalec eksperimentira, ustvarja in izdeluje prototipe modelov (Razzouk in Shute 20 2, 330). To pomeni, da je v jedru oblikovalskega mišljenja ustvarjanje in eksperimentiranje. Gonilna sila tega načina mišljenja je nezadovoljstvo s trenutnim stanjem in odločenost, da se problem reši.

Način reševanja in iskanja novega znanja marsikje nastane tako, da se rezultati ovrednotijo. Razzouk in Shutte (2012,333). Tako je tudi pri oblikovalskem mišljenju, kjer se rešitve iščejo prek različnih prototipov, ki se jih vrednoti in nadalje nadgrajuje. Tradicionalno je pogled na kreativno delo zamegljen, morda celo romantično prikazan (denimo Phillipe Starck).

Johansson-Skoldbergova, Woodilla in Cetinkaya (2013, I2 I) pravijo: $\gg V$ menedžerskem okolju je dizajnersko razmišljanje opredeljeno kot naj- 
boljši način biti kreativen in inovativen. V oblikovalskem okolju pa dizajnersko razmišljanje delno ignorirajo in ga jemljejo kot nekaj samoumevnega.«

Razzouk in Shutte $(2012,333)$ v področje kreativnega dela vključita tudi analitični pristop. Tako govorita o iskalcih (finder) in izdelovalcih (maker). Oblikovanje tako postane logična aktivnost, ki se začne $\mathrm{z}$ analizo neznanega objekta, nadaljuje pa s poskusom generalizacije in $s$ tem ustvarjanja novega znanja (Hatchuel in Weil 2003).

Pogosto je pri oblikovanju zaznati elemente naključja in 'aha efekt'. Suwa, Gero in Purcell (1999) so ugotovili močno povezavo med nepričakovanimi odkritji in izboljšavami ter zahtevami v okolju. Gre za dvosmerni proces, ko nepričakovana odkritja postanejo sila za izboljšave in izboljšave povzročijo nova nepričakovana odkritja.

Brown (2009, 4), ki je ustanovil IDM in je eden prvih, ki je začel predstavljati oblikovanje $\mathrm{v}$ managementu $\mathrm{v}$ praksi, poudarja, da se oblikovalsko mišljenje začne $\mathrm{z}$ veščinami, ki jih oblikovalci pridobijo $\mathrm{v}$ formalnem in neformalnem izobraževanju, pri čemer morajo imeti tudi zmožnosti biti intuitiven, spoznavati vzorce, ustvarjati ideje.

Preglednica 8: Design thinking

\begin{tabular}{|c|c|}
\hline Avtor & Koncept \\
\hline Kimbell 2011,285 & $\begin{array}{l}\text { Design thinking je način, kako oblikovalci rešujejo problem, je vrednost podjetja, ki } \\
\text { skuša inovirati, in družb, ki skušajo ustvariti spremembe. }\end{array}$ \\
\hline Rowe 1991 po Kimbell 201 I & $\begin{array}{l}\text { Postopkovni vidik oblikovalskega mišljenja vključno z oblikovalskimi procesi in } \\
\text { splošnimi principi. }\end{array}$ \\
\hline Kimbell 2011,285 & Design thinking kot kognitivni stil, glavna teorija oblikovanja, vir za organizacije. \\
\hline Razzouke, Shute 2012 & $\begin{array}{l}\text { Kdor uporablja oblikovalsko mišljenje, mora imeti različne karakteristike (vizualizaci- } \\
\text { ja, kreativnost). }\end{array}$ \\
\hline Razzouke, Shute 2012 & $\begin{array}{l}\text { Začetek oblikovalskega procesa so potrebe in nezadovoljsto s trenutnim stanjem in } \\
\text { odločenostjo, da je treba nekaj ukreniti, da se reši problem. }\end{array}$ \\
\hline Razzouke, Shute 2012 & Vključuje kreativno mišljenje v proizvajanju rešitev za probleme. \\
\hline Razzouke, Shute 2012,330 & $\begin{array}{l}\text { Oblikovalsko mišljenje je v osnovi opredeljeno kot analitičen in kreativen proces, ki } \\
\text { vključuje osebo in daje priložnosti eksperimentirati, ustvarjati in izdelovati prototipe, } \\
\text { zbirati povratne informacije in preoblikovati. }\end{array}$ \\
\hline
\end{tabular}

V teoriji in praksi sta se uveljavila dva izraza, in sicer 'design thinking' in 'designerly thinking'. Johansson-Skodlbergova, Woodilla in Cetinkaya (2013) poudarja, da je design thinking poenostavljena različica. Po njenem mnenju je designerly thinking način opisovanja oblikovalskih metod, ki so vključene $v$ akademsko ali praktično menedžersko razpravo. 
Gre predvsem za to, kako razmišljajo pri reševanju kompleksnih problemov, kjer je možnih več rešitev (Buchanan 1992).

$\mathrm{V}$ preglednici 8 podajamo pregled ključnih pojmov pri opredelitvi oblikovalskega mišljenja.

Kolko $(2015,70)$ poudarja, da je design thinking osnovno orodje za poenostavitev in počlovečenje. Zato design thinking ne more biti nekaj posebnega, nekaj zunaj, ampak mora biti osnovno znanje in veščina. Menedžerji na nek način različno gledajo na dizajnersko mišljenje, imajo do njega različen odnos.

V nadaljevanju prikažemo menedžerski pogled.

\section{Menedžerski pogled na oblikovalsko mišljenje}

Znotraj tega menedžerskega diskurza se design thinking ' še naprej deli na tri razumevanja. Eno je, da se uporablja kot način upravljanja oblikovanja in inovacij, kot upravljanje in reševanje problemov znotraj organizacije, in drugo kot del menedžerske kulture.

Za menedžerski vidik design thinkinga je Kolko (2015) izjavil, da je »splošno znan kot oblikovalsko mišljenje - empatija z uporabniki, disciplina prototipov in toleranca za neuspeh glavna med njimi, najboljše orodje za ustvarjanje tovrstnih interakcij in razvijanje odzivne, prožne organizacijske kulture $\ll$.

Neumeier (2008, 19), predsednik Neutrona, je poudaril prav navdihujočo misel o tem, da je oblikovalsko mišljenje del menedžerskega inoviranja, ki bo Six Sigmo vrglo s prestola. Pravi, da bo oblikovalsko mišljenje kot menedžersko orodje preoblikovalo procese, se ustavilo v razvoju in laboratorijih, preželo vse dejavnosti in poravnalo finance s kreativnostjo ter spremenilo pravila investiranja. Posebej priporoča, da je treba začeti z oblikovanjem in ne tehnologijo, če želimo imeti dobiček na dolgi rok.

Lockwood $(2009,83)$ je eden od ustanoviteljev Inštituta Design Management in profesor na Pratt univerzi. Pravi, da je oblikovalsko mišljenje del managementa in mu pomaga reševati nerešljive probleme. Pri tem vidi dizajn management kot vodenje oblikovalskih procesov, operacij in oblikovalskih izdelkov. Morda je problematično, da vidi oblikovalsko mišljenje kot del procesa inovacije in kot metodo, $s$ katero oblikovalci iščejo nove koncepte, izdelke, storitve.

Heylingen, Cavallin in Bianchin (2009) vidijo oblikovanje kot ustvarjanje znanja.

Velja omeniti, da je na tem področju terminološka zmeda. V slovenski literature sem zasledila zgolj termin dizajnersko razmišljanje, ki ustreza pojmu design thinking, ne pa tudi ustreznega prevoda za designerly thinking. 
Boland idr. (2008) v raziskavi načina dela arhitekta Franka Gheryja iščejo ključ do uspešnega in kreativnega mišljenja, razvoja in vodenja projekta. Ugotovili so, da je za ustvarjanje zadovoljnega in funkcionalnega sveta potrebna dodatna čustvena energija, ki pa nastane tako, da se navdihne ljudi, da sanjajo o novih podobah, možnostih.

Isti avtorji poudarjajo, da je delo oblikovalcev, arhitektov, načrtovalcev specifično drugačno, a vendar bi se morali menedžerji truditi razvijati nove modele, teorije in konceptualizacije svojega posla, trga, okolja, tekmecev. Poenostavljeno prenašanje oblikovanja v management je težko uspešno. Treba bi bilo razviti nove organizacijske oblike, ki bi morale ohranjati organizacijo $\mathrm{v}$ dinamičnem stanju. $S$ tem bi menedžerji razvijali nove modele, teorije in konceptualizacije svojega posla.

Kot vidimo, gre za dva različna pogleda, oblikovalsko mišljenje kot proces in oblikovalsko mišljenje kot metoda. Proces so koraki, ki vodijo $\mathrm{k}$ nekemu cilju, ki je nazorno opredeljen, je nenehna aktivnost, serija sprememb. SSKJ (b. l.) pojem proces opredeli kot: med seboj povezani pojavi, ki se vrstijo v času po določenih naravnih in družbenih zakonitostih. Metoda pa so logični predpisani koraki, ki vodijo do nekega cilja. Po SSKJ (b. 1.) je: metoda navadno $s$ prilastkom oblika načrtnega, premišljenega dejanja, ravnanja ali mišljenja za dosego kakega cilja; način, postopek. Proces so medsebojni pojavi, ki se vrstijo v času po določenih naravnih zakonitostih. Metoda pa je oblika načrtnega dejanja.

Glede na to, da večina akademikov in proučevalcev govori o oblikovalskem mišljenju kot o procesu, menimo, da je ravno ta »spontanost « in nenehna aktivnost bistvena za razumevanje pojma oblikovalskega mišljenja. Srž problema v opredelitvi tega pojma je v tem, da je v menedžerskem diskurzu uporabljen redukcionistični vidik, ki vidi oblikovalsko mišljenje kot orodje in oblikovanje kot zunanjo obliko. To je zelo lepo opisal kritik Mc Guirk (2013), ko je opisoval intervju z direktorjem oblikovanja Samsunga, ki je priznal, da se šele zdaj, po Applu, začenjajo zavedati, kaj je oblikovanje. 


\section{Metodologija}

Raziskava temelji na kvalitativni paradigmi raziskovanja, kot jo opredeljujejo Easterby-Smith, Thorpe in Lowe (2007). Kvalitativna metodologija temelji na socialnem konstruktivizmu in interpretivizmu in poudarja pomen konteksta za raziskovanje in razumevanje pojavov. McEvan in McEvan (2003) podata kratek oris izvora sodobnega razmišljanja, rabe in opredelitev pojma kvalitativne raziskave. Poudarjata, da jo še vedno mnogi povezujejo $\mathrm{z}$ etnografijo in naturalistično raziskavo. Hkrati opozarjata, da je poskus, da bi jasno in čvrsto umestili sodobne kvalitativne študije in podobne kategorije poskus, ki raziskovalca frustrira (McEwan in McEwan 2003, 77). Kot lastnost kvalitativne raziskave omenjata tri značilnosti: (a) je naturalistična (podatke zbira raziskovalec na terenu), (b) je opisna, kar pomeni, da temelji na besedah, in (c) je usmerjena na pomen in razlago oziroma interpretacijo opazovanega. Pojem kvalitativne raziskave je torej kompleksen, predvsem pa pokriva več vrst oziroma pristopov $\mathrm{k}$ raziskovanju.

Ena od vrst kvalitativne raziskave je študija primera. O njej pišemo kot o novosti, čeprav Starmanova (2013) opozarja, da je študija primera že dolgo uporabljena, npr. v psihologiji kot »case work «, v 60. in 70. letih prejšnjega stoletja pa se je uveljavila kot odgovor na potrebo po drugačnih raziskavah, pristopih in podatkih. Posebej je študija primera primerna za raziskave v managementu, izobraževanju in socialnem delu. Študija primera pomeni, da raziskovalec pridobi poglobljen vpogled $\mathrm{v}$ posamezen projekt, organizacijo, politiko, program, dogodek $\mathrm{z}$ več perspektiv v naravnem kontekstu (Simons 2009, 21). 
Obstaja več vrst študije primera. Ena izmed njih je preiskovalna ali eksploratorna študija primera (Yin 200I). Izvedemo jo z namenom preiskati relativno novo področje, problem, pojav. Glede na pomanjkanje empiričnih raziskav s tega področja bo raziskava zasnovana kot kvalitativna študija primera (Stake 2013; Yin 200I), pri čemer primer predstavlja »dizajnerska kultura«. Preiskovalno študijo primera smo zasnovali kot multiplo študijo primera, saj smo v raziskavo vključili štiri podjetja. Analiza pa ni potekala po podjetjih - posameznih primerih, ampak, kot pravi Yin (200I), po temah, ki smo jih razvili v fazi analize podatkov.

\section{Namen in cilji}

Namen raziskave je bil kritično preučiti fenomen dizajnerske kulture $\mathrm{v}$ slovenskih podjetjih, ki so osvojila prestižno oblikovalsko nagrado Red 48 Dot.

V raziskavi smo sledili naslednjim ciljem:

- podati pregled sodobne literature in virov s področja organizacijske kulture, znamčenja in dizajn managementa ter oblikovalskega mišljenja;

- osvetliti pojem oblikovalske kulture tako v širšem kulturološkem kot tudi managerskem pogledu;

- ugotoviti pomen, ki ga pripisujejo oblikovanju slovenska proizvodna podjetja, ki so osvojila nagrado Red Dot;

- ugotoviti (ne)prisotnost dizajnerskega razmišljanja kot dela organizacijske kulture;

- oblikovati priporočila za nadaljnje raziskovanje in prakso.

\section{Raziskovalna vprašanja}

Glede na zgornje cilje smo si zastavili naslednja raziskovalna vprašanja:

- Kako je v sodobni literaturi opredeljen pojem dizajnerskega mišljenja, dizajnerske kulture in dizajn managementa ter brandinga?

- Kakšen pomen pripisujejo oblikovanju vršni management in zaposleni v preučevanih podjetjih?

- Ali je oblikovanje del strateške usmeritve $\mathrm{v}$ preučevanih podjetjih?

- Kakšna je vloga zaposlenih v preučevanih podjetjih pri oblikovanju?

- Ali v podjetjih, nagrajenih z nagrado Red Dot Design Award, obstaja dizajnerska kultura? 


\section{Vzorec}

V Sloveniji je I3 podjetij, ki so osvojila prestižno oblikovalsko nagrado Red Dot. To je mednarodna nagrada za oblikovanje izdelka in za oblikovanje komunikacije, ki jo že od leta 1954 podeljuje Design Zentrum Norderhein Westfalen v Essnu, Nemčija'. Med prejemniki te nagrade nismo vzorčili, ampak smo povabili k sodelovanju vsa podjetja razen dveh (eno $\mathrm{v}$ stečaju in eno, ki je samo oblikovalsko podjetje in ponuja oblikovalske storitve, nima pa lastnega izdelka in proizvodnje), ki so prejela nagrado Red Dot v zadnjih desetih letih. Če gledamo z vidika vseh podjetij v Sloveniji, potem predstavlja vključitev podjetij, ki so prejela Red Dot nagrado, namenski vzorec. Izbrali smo tista podjetja, ki nam o preučevanem problemu, oblikovalski kulturi, lahko največ povedo. Izbor teh podjetij temelji na predpostavki, da imajo zelo razvito in ubesedeno oblikovalsko kulturo, če prejmejo tako prestižno nagrado.

Podatke o prejemu nagrade smo našli na njihovih spletnih straneh in na spletni strani organizacije Red Dot. Znotraj podjetij smo kvotno vzorčili, torej oblikovali kvotni vzorec, ki sodi med nenaključne vzorce. V vsakem podjetju smo zaprosili za sodelovanje vršni management, srednji management, zaposlene $\mathrm{v}$ oblikovalskem ali razvojnem oddelku ter zaposlene v proizvodnji. Predstavnike vršnega, srednjega managementa, oddelka za razvoj in oblikovanje in proizvodnjo smo vključili iz različnih razlogov. Vršni management - lastniki oziroma direktorji - vpliva na strateške usmeritve in vizijo. Pri izbiri predstavnikov srednjega managementa smo se prilagodili posamezni organizacijski strukturi organizacije, saj te niso enako velike in imajo različne strukturne nivoje. Zajeli smo vodje oddelkov proizvodnje, ki neposredno vplivajo in nadzirajo delo delavcev v proizvodnji ter poznajo posebnosti in način dela. Prav tako pa smo vključili tudi predstavnike oddelka za raziskovanje in razvoj oziroma oddelka, ki je povezan z oblikovanjem. Nekatera podjetja imajo svoje oblikovalske oddelke, nekatera pa za to najemajo zunanje oblikovalske agencije in oblikovalce. Zadnja skupina so predstavniki proizvodnje.

Velikost vzorca je bila različna glede na velikost podjetja in pripravljenost za sodelovanje. Od i podjetij so se odzvala štiri. To je naš vzorec. Podjetja sodijo $v$ majhna in srednja podjetja po številu zaposlenih, delujejo pa na različnih proizvodnih področjih, ki jih zaradi zagotavljanja anonimnosti posebej ne izpostavljamo.

$\mathrm{V}$ podjetju A so bili vključeni v raziskavo trije zaposleni (direktor, oblikovalka in delavec iz proizvodnje), sicer pa je v podjetju 20 zaposle- 
nih. $V$ podjetju B je sodelovala ena oseba, ki je sebe opredelila kot $\gg$ deklica za vse po malem«, direktor je moral intervju odpovedati zaradi obveznosti, sicer je I 4 zaposlenih. V podjetju $\mathrm{C}$ so sodelovali štirje zaposleni, in sicer ena oseba iz oddelka produktno vodenje, dve vodji proizvodnje in ena oblikovalka, zaposlenih v podjetju je 600 . V podjetju D je sodelovalo šest oseb, in sicer tri iz tehnologije, ena oseba iz marketinga in dve osebi iz proizvodnje, zaposlenih je 246 . Skupno smo izvedli 14 polstrukturiranih intervjujev.

\section{Metode zbiranja podatkov}

Podatke smo zbrali s polstrukturiranim intervjujem, ki ga Bryman (2004) poimenuje globinski polstrukturirani intervju (angl. in-depth semistructured interview).

Polstrukturirani intervju je med dvema ekstremoma, to je strukturiranim in nestrukturiranim intervjujem. $Z$ intervjuji smo pridobili podatke, ki so nam dali avtentičen vpogled v izkušnje in interpretacije praks naših intervjuvancev (Kvale 1996; Silverman 2001). Pri omenjenem intervjuju si raziskovalec poleg splošne sestave intervjuja, $\mathrm{v}$ kateri postavi cilje, ki naj bi jih z intervjujem dosegel, vnaprej pripravi tudi nekaj bistvenih vprašanj, navadno odprtega tipa, ki jih postavi vsakemu vpraševancu, preostala vprašanja pa oblikuje sproti med potekom intervjuja. Pol strukturirani intervju je zelo prožna tehnika zbiranja podatkov. Njegova značilnost je, da omogoča zbiranje podatkov na osnovi vprašanj odprtega tipa, kar pomeni, da lahko med intervjuvanjem dodajamo podvprašanja in tako pridobimo poglobljen vpogled $\mathrm{v}$ naš preučevani problem. Uporaben je pri študiji primera in tudi na večjih vzorcih, uporabi se lahko kot samostojna tehnika zbiranja podatkov ali v kombinaciji z drugimi tehnikami (Guba in Lincoln 1994).

Podjetjem smo vnaprej poslali nabor vprašanj. Ta so bila:

- Kaj je najpomembnejša vrednota v vašem podjetju?

- Ali je oblikovanje del strateške usmeritve v vašem podjetju? Pojasnite, prosim, vaš odgovor na primeru.

- Kaj vi razumete pod izrazom dizajnerska ${ }^{2}$ kultura?

- Kako se kaže dizajnerska kultura v vašem podjetju?

- Kako nastajajo oblikovalske rešitve?

- Kakšen pomen pripisujete oblikovanju?

2 V vprašanjih smo ohranili angleške izraze ' dizajn' dizajnerska kultura', ker je to del jezika, ki ga podjetja poznajo in uporabljajo. Tudiv intervjujih nismo prevajali angleških izrazov, ki so jih uporabljali intervjuvanci, ker bi se s tem izgubil poudarek. 
Vprašanja smo skupaj s prošnjo za sodelovanje poslali po e-pošti vsem I I. podjetjem. Tako so lahko bolje razumeli našo prošnjo po vključitvi zaposlenih iz različnih organizacijskih funkcij v intervjuje. Med intervjujem smo dodajali podvprašanja in spodbujali intervjuvance $\mathrm{k}$ čim kompleksnejšim odgovorom.

\section{Triangulacija}

Triangulacija je $\mathrm{v}$ kvalitativnem pristopu pomembna, saj z uporabo treh ali več teorij, virov, metod povečujemo kredibilnost kvalitativne raziskave. Mi smo izvedli triangulacijo po virih v vsakem podjetju s tem, da smo intervjuvali predstavnike različnih oddelkov v sodelujočih podjetjih.

\section{Metode analize podatkov}

$\mathrm{Za}$ analizo podatkov smo uporabili kombinacijo dveh metod: metodo analize vsebine (angl. content analysis) in utemeljeno metodo (grounded theory analysis). Če o preučevanem fenomenu ne obstaja dovolj predhodnega znanja, se za oblikovanje kategorij znotraj analize vsebine priporoča induktivni pristop (Mayring 2000), kar nas vodi od specifičnega $k$ splošnejšemu; opazujemo posamezna dejstva in jih kombiniramo v večjo celoto.

Utemeljena metoda nas je sistematično vodila skozi proces vzpostavljanja znanja in razumevanja »kaj se $\mathrm{v}$ resnici dogaja « $\mathrm{s}$ preučevanim fenomenom - dizajnersko kulturo, ob upoštevanju raziskovalčevega filozofskega izhodišča (Birks in Mills 20ı I). Razvoj novega vedenja izhaja iz podatkov, pridobljenih od udeležencev, ki so sodelovali v procesu (Strauss in Corbin 1990). K analizi smo pristopili tako, da smo vse intervjuje prepisali. Potem smo po več iterakcijah oblikovali teme in kategorije ter celoten tekst kodirali. Nato smo začeli analizo in interpretacijo. Čeprav je naša študija primera zasnovana kot multipla študija primera, nismo analizirali vsakega podjetja posebej, temveč smo se osredinili na naš primer - oblikovalsko kulturo, kot jo razumejo in interpretirajo intervjuvanci. $S$ tem smo iskali skupne značilnosti primera, vzorce pojmovanj, pomen in prakse ter jih izrazili skozi oblikovane kategorije.

\section{Predvidene omejitve in predpostavke pri obravnavanju problema}

Ločimo metodološke in vsebinske omejitve.

\section{Metodološke omejitve}

Gre za eksploratorno multiplo študijo primera, zato ugotovitev ne moremo statistično posploševati, kar pa niti ni namen te študije. V vzorec 
smo zajeli le podjetja, ki so dobila prestižno oblikovalsko nagrado Red Dot, ne pa tudi tistih, ki je niso, vendar pa delujejo v enakih panogah. Pri vzorčenju znotraj podjetij nismo imeli neposrednega vpliva na izbor intervjuvancev, ampak so podjetja določila predstavnike oziroma sogovornike. Področje empirično ni raziskano, zato smo zasnovali eksploratorno študijo primera.

\section{Vsebinske omejitve}

Področje dizajn managementa so v veliki meri prevzela svetovalna podjetja in zato je s tega področja dokaj malo raziskav, posebno novejših. Tako da je treba pri delu povezovati različna področja, ki delno obravnavajo to tematiko. V slovenskem prostoru je poznavanje dizajn managementa in področij, ki to obravnavajo, še vedno relativno šibko. To je problematično zlasti z vidika rabe terminologije. Jezik/terminologija je posebna omejitev, saj komunikacija poteka $\mathrm{v}$ žargonu, $\mathrm{v}$ katerem je polno tujk in angleških izrazov. Prevodi predstavljajo poskus poenotenja s strani avtorjev, zato so lahko mestoma tudi napačni. V oklepaju se zato ohranjajo izvirni izrazi v angleškem jeziku.

Skrb, namenjena pravilni opredelitvi osnovnih pojmov, in zelo malo raziskan pojav oblikovalske kulture daje delu pionirski značaj. Med drugim bo ponudilo terminološki prispevek k preučevanemu področju.

\section{Red Dot Award}

Red Dot Design Award je mednarodna nagrada za dizajn izdelka in dizajn komunikacije, ki jo že od leta 1955 podeljuje Design Zentrum Nordrhein Westfalen v Essnu v Nemčiji. Obstajajo kategorije za dizajn izdel$\mathrm{ka}$, dizajnerske agencije in dizajnerske koncepte. Zmagovalni projekti so predstavljeni v Muzeju Red Dot Design v Essnu in na Tajvanu. Leta 2014 so prejeli več kot 15.500 prijav iz 70 držav (Red Dot b. 1.). 


\section{Analiza in interpretacija}

Zbrane podatke smo analizirali s kombinacijo dveh metod analize podatkov: metodo analize vsebine (content analysis method) in utemeljeno metodo (grounded analysis method) (Easterby Smith, Thorpe in Lowe 2007). Naredili smo prepis intervjujev, nato smo iz vsebine odgovorov oblikovali kategorije. Te so: »Kam gremo?«, »Oblikovalska kultura « in »Nagrade «. Znotraj kategorij smo identificirali različne teme, ki smo jih prikazali kot podkategorije. Tako imamo tri kategorije in sedem podkategorij. Znotraj vsake posamezne kategorije oziroma podkategorije smo iskali vzorce oziroma skupne značilnosti, ki se povezujejo z vsebino kategorije. Izjave intervjuvancev navajamo dobesedno in kot zaokrožene celote - misli oziroma sporočila, ki podajajo kontekst izjave in samo jedro - sporočilo, ki ga nosi dobesedna izjava. Ker so nekateri intervjuvanci iz velikih, drugi pa iz majhnih podjetij in ta razlika v delovanju podjetja, njegovi strukturiranosti, šteje, nismo analizirali podatkov posebej po skupinah udeležencev (lastnik/manager, oblikovalci in razvojniki in proizvodnja, ampak smo njihove izjave soočali predvsem vsebinsko in ne »položajno «. Podatke smo hkrati z analizo tudi interpretirali, pri čemer smo uporabili dosegljivo literaturo in vire.

\section{Kam gremo?}

Intervjuvanci govorijo o dveh usmeritvah, trendu in strategiji. Trend ponazarja splošno smer, v katero se nekaj razvija ali spreminja. Povezan je $s$ predvidevanjem, kaj bo $\mathrm{v}$ prihodnosti. Medtem ko je strategija proces, kjer se na osnovi vizije in misije podjetje odloča kam gre. Se pravi, da je 
razlika, od kod usmeritev prihaja. Strategija je osnovana na osnovi tega kdo smo in kam gremo, trend pa na osnovi tega, kam gre trg, kaj se dogaja na trgu. Woudhuysen (2013) pri tem pravi, da trende pogosto določajo kar dizajn managerji in oblikovalci, ki za snovanje trendov niso dovolj usposobljeni. Pri tem gre za dva pogleda, ali nekdo želi biti snovalec trendov ali trendom samo sledi. Podjetja delujejo v nekem širšem okolju, zato sta pri odločanju zagotovo pomembna oba vidika. Pri tem lahko rečemo, da je trend bolj povezan $s$ samim oblikovanjem kot $\mathrm{z}$ vizualno predstavitvijo. Zhou, Yim in Tse (2005) pri tem pravijo, da je sledenje trendom ustrezno za mainstream podjetja, vendar pa s tem lahko zanemarimo nove trge, ki se šele porajajo. Za nova ali nastajajoča podjetja je pomembno, da ustvarjajo trende, saj so ustvarjalci trendov oziroma. trendsetterji tisti, ki odpirajo in se uveljavljajo na novih trgih. Sicer pa velja, da moramo poznati oba vidika in se odločiti ali je strategija podjetja biti trend setter ali ne.

\section{Trend}

Kot smo že povedali, je trend poskus napovedovanja prihodnosti na osnovi sedanjosti. Osnovan je na podlagi tega, kam gredo okolje, trg, analiza demografskega stanja. Pogosto ga povezujemo z modo. Vendar je trend dolgoročnejši, je usmeritev in ne le smer za naslednjo sezono. Tudi Oxfordov slovar (b. 1.) pod trend ponudi sopomenko 'fashion' - moda, čeprav izraz fashion pomeni dajati obliko. Tako ga podobno vidijo $v$ tretjem podjetju. Simmel (1957) v družbenem kontekstu opredeli modo kot obliko imitacije, kjer pripadniki nižjega sloja skušajo slediti tistim iz višjega. Ko nova moda ('fashion') postane popularna, si morajo izmisliti nekaj novega. Lahko vidimo, da je avtor razumel modo v kontekstu 'trendsetterjev' in 'trendfollowerjev', aplicirano na tedanje družbeno stanje. Tudi na področju svetovanja managementu se pojavlja besedna zveza 'management fashions', kjer gre za nenehne nove ideje in modele svetovalnih podjetij managerjem (Benders in Van Veen 200I), kar je tudi nevarnost pri dizajn managementu kot redukciji na novo managersko modno muho.

Vendar pogosto trendi niso le ideje nekaterih nadarjenih in vizionarskih posameznikov. Kot je vidno v nadaljevanju, pogosto sodelujejo cele skupine, ki združujejo različna znanja. Za napovedovanje trendov v prihodnosti se uporabljajo različni računalniški modeli, ki na osnovi statističnih podatkov napovedujejo prihodnje trende. Avtorja Tucker in Kim (20I I) pravita, da je to pomembno, da lahko oblikovalci in inženirji nare- 
dijo prihodnjo generacijo izdelkov, preden ti postanejo mainstream. Tudi onadva poudarita, da ni dobro biti mainstream, saj s tem izgubiš konkurenčno in razlikovalno prednost. Trendsetter je nekdo, ki širi novo idejo, preden jo sprejmejo drugi. Lahko rečemo, da je biti trend setter pomembno, saj to opredeljuje pozicijo na trgu, ki omogoča razlikovanje, $v$ časovnem pogledu strateško prednost (Saez-Trumper idr. 20I2).

Trend kot kratkoročna usmeritev, oziroma kot nakazovalec prihodnjih usmeritev in gibanj se kaže z s tem, ko oseba $\mathrm{A}_{2}$ pravi: »Predvsem hočemo naprej poriniti izdelke, ki imajo neko dodano vrednost za uporabnika. To so vsi ti oblikovani produkti. Poudarek je na stolu Nicolas. Tukaj želimo doseči da bo izdelek dostopen za množico in ne drag kos za peščico ljudi. Tako da morda s tem ... to so naši paradni konji s katerimi želimo pokazati kaj znamo narediti in da je kvaliteta na prvem mestu, uporabniška izkušnja, udobje. In pač želimo biti trend setterji ne trend followerji. Ker če ne lahko konkuriraš le s ceno, mi pa tega ne želimo, ker tako dela večina slovenskih podjetij in tu ni nobene dodane vrednosti. To je samo, kdo je cenejši, in za tistega se odločijo. Tako da ceno pa lahko določa ravno ta dodana vrednost, ki jo prinese oblikovanje. To se kaže tudi da hodimo na vse večje tuje sejme, Nemčija, Milano, Orgatec in v bistvu London. Letos pridejo na vrsto vsi ti sejmi, razen Milana, ki je že sedaj. Letos ni office, pa tudi Moskva. Kjer se kaže le izdelke z dodano vrednostjo in želi s tem dokazati tujim strankam, potencialnim, da se odločijo za nas, da smo drugačni, damo na kvaliteto in dodano vrednost.«

To lahko razumemo, da glede oblikovanja izdelkov v panogi obstajajo podjetja, ki narekujejo trende, usmeritve, in podjetja, ki tem usmeritvam sledijo in jih posnemajo. Opiše, da se podjetja srečujejo na različnih sejmih, kjer vidijo, kaj delajo drugi, in na podlagi tega predvidevajo in načrtujejo svoje delo v prihodnosti. $S$ pozicijo trendsetterja je povezana tudi poslovna uspešnost, saj omogoča višjo dodano vrednost, višjo ceno. Torej biti trendsetter, biti v trendu, ni le stvar neke modne muhe, temveč del pozicioniranja na trgu. $S$ tem, ko oseba $A_{2}$ pravi, da želijo biti trendsetterji, pove tudi nekaj o strategiji podjetja. Se pravi, da težko ločimo trend in strategijo oziroma obstajajo nekakšni odnosi med njima.

A I opredeljuje to s potrošniško logiko: »Ne samo, da nekdo vidi nekaj lepega in mu je to všeč. To je za mene ta potrošniška logika, kjer 'aha, všeč mi je, to bi kupil'.«

Trend je pogosto razumljen kot nekaj lepega, trenutnega.

A I pravi: »Razlika je samo ali je dobro narejeno. Se pravi z dolgoročnim pogledom. Ali samo, zdaj bom nesramen, kickstarterski projekt. Se 
pravi, nekaj se naredi, proda in nato bomo videli kako naprej. Kratkoročno se mi zdi, da so potem omejeni s trajnostnim biznisom.«

Intervjuvanci govorijo o predpostavki, da so kickstarter in drugi sorodni projekti izdelki ali podjetja del trenda, hkrati pa so brez prave dolgoročne strategije in vizije. Njihovo mnenje je zanimivo zato, ker nasprotujejo temu, kako so prikazani nameni kickstarterja in drugih platform. Te so namreč namenjene spodbujanju inovacij in začetnih poskusov (Gerber, Hui in Kuo 20I2). Izsledki raziskave Mollick in Kuppuswamy (20I4) kažejo, da je velika večina uspešnih podjetij nadaljevala z delom in omogočila zaposlitev dodatnih ljudi. Pri tem je pomemben dejavnik, da so bila ta podjetja že prej dobro strateško pripravljena (prav tam). Lahko se strinjamo, da je kickstarter nekakšna moda, trend vstopanja na trg in preverjanja novih konceptov, vendar težko posplošimo, da so vsi projekti brez strategije.

A I navede tudi: »Življenjska doba podjetij se zmanjšuje z I 2 na 7 let.«

Knight (2014) piše, da se je za 500 podjetij S\&P življenjska doba skrajšala s 60 na i 8 let. V nadaljevanju avtor svetuje, da dolgoročna strategija podaljša življenjsko dobo podjetja. Skrajševanje življenjske dobe podjetij ima več vidikov. Eden izmed njih je hitrost družbenih sprememb in zmožnost podjetja, da se spremembam prilagodi, drugi vidik pa je povezan $z$ dolgoročno strategijo.

Zanimivo je, da oseba Bı vidi povezavo trenda s kapitalom.

BI: »Trend je vedno povezan s kapitalom. Stvari, ki se dobro prodajajo, so špica, sploh pri denimo solo oblikovalcih, da te vzame ena večja oblikovalska hiša, da lahko delaš za 'brand', pomeni, da moraš slediti nekim trendom, moraš delati neke prepoznane oblike. Ki pa mogoče slučajno sovpadajo s tistim, kar ljudi zanima. Kar je ta trenutek nekaj novega, lepega. Ni pa nujno, da je ves dizajn ali vsa oblika trendovska. To se mi zdi bolj stvar kulture, da ljudje konstantno razvijajo nove oblike, forme, ki niso nujno najbolj prodajane in najbolj v trendu. Se pravi, da je trend povezan s prodajo, kultura $\mathrm{z}$ nečim trajnim.«

Vidimo, da gre za razumevanja trenda v pomenu mode, mainstreama. Se pravi, če si moden, v trendu, potem imaš veliko dela. Obenem izpostavi vidik oblikovanja, kjer je to razumljeno kot nenehen proces iskanja novih oblik, konceptom. To pa poveže s kulturo, kjer je vsebovan nek element vrednot.

$\mathrm{C}_{3}$ : »Nisem seznanjen. Itak imamo vzorce naredimo, in ko je nova kolekcija, novembra delamo že naslednjo sezono, in ko bo vse, se dobimo dol v show roomu in razstavimo in vsak od vodij, oblikovalke in razvoj 
pove: če bi popravili to, se to ne vidi, in skupaj potem najdemo rešitve za redno proizvodnjo, da bo lažje.«

Iz tega izseka intervjuja vidimo, da podjetje vsako leto ustvari novo kolekcijo. Tudi izraz kolekcija je tak, ki prihaja iz mode, zato je smotrno osvetliti te izraze.

$\mathrm{C}_{\mathrm{I}}$ prav tako omeni trend kot enega izmed dejavnikov. Pravi: $\gg$ Ključno, ker je veliko pozornosti na dizajnu. Da je vsako leto update, korak naprej. Da smo v trendu. Če bi želeli imeti interne, nekoč smo jih imeli interne grafike. Ampak smo se odločili za outsourcing. Mi smo v smučarski industriji in imamo izjemne oblikovalce. Ekipa, s katero boste govorili, ima izjemen in konceptualen element, da pretvori idejo v realizacijo. Vendar se moramo zavedati, da smo zaprti v zimsko industrijo. Agencija pa dela dva, tri, štiri mesece za nas. Istočasno dela za mnogo drugih industrij in ima bistveno večjo širino kot mi. Zato vidimo pomembnost agencij tudi kot neki zunanji faktor, ki nas kdaj usmeri. Pomembno je tudi dejstvo, da imamo dolgoletne partnerje. Delamo z Gigo Design in Sonda Design studiem iz Hrvaške, oba sta desetletna partnerja. Mi verjamemo, da se še niso izpeli. Tudi sami delajo za to, da imajo nove in nove sodelavce. Tudi ni samo ena oseba zadaj in samo ena oseba dela dizajn. Da nam zagotavljajo širino, nas poznajo, vejo kaj je Elan. Tudi oni rečejo, nov oblikovalec je naredil, samo vidimo da ni čisto, to je Rossignol. Ne bomo šli v to smer.«

Zavedajo se, da je za načrtovanje trendov potrebna širina, poznavanje večjih panog, sledenje spremembam in na podlagi tega napredovanje. Kar je tudi zanimivo, je, da se zavedajo pomembnosti usposobljenosti zaposlenih, vendar vse znanje in talent nista dovolj za uspešen nastop na trgu in postavljanje novih trendov. $V$ bistvu enači trend $\mathrm{z}$ mainstreamom, kar bi lahko rekli, obenem pa bi lahko rekli, da je pozicija na trgu, ki je odraz kapitala.

$\mathrm{B}_{\mathrm{I}}$ : »Vsako podjetje, če je podjetje, je povezano s kapitalom. Če delamo stvari, ki so oblikovane avtomatično pomeni, da smo podrejeni nekim trendom. Tako. Če ne čisto praktičnim trendom, kvadratura, trend pri kvadraturi, ampak to nima povezave z obliko, ampak tudi posledično manjše stvari, manjše hiše, velike okenske odprtine, to so vse stvari ki so v trendu, ki pred sto leti niso bile v trendu.« ... »Trudimo se obdržati neke estetske norme, ki so nam blizu. To je kulturno, da se ne podrejamo čisto kapitalu, če ne bi šli v masovno produkcijo. Treba je gledati stvari. Tudi oblika je malo podrejena temu, kaj lahko prodamo. Vsi bi delali neke zelo nerealne stvari, ki jih nihče ne bo kupil. Po domače. Mi če hočemo delati za trg, pač delamo serijsko proizvodnjo, potem si ne moremo 
omisliti hiše, ki je predraga. Lahko mu tako hišo posebej delamo, ampak če delamo serijske hiše za trg, so podrejene nekemu kapitalu, oziroma morajo biti vsaj malo pragmatične, da se vse tri postavke cena, kakovost, čas poklopijo.«

Podjetje se zaveda, da se mora za obstoj na trgu v nekem segmentu podrediti tržnim zakonitostim in zahtevam, ki so stvar sedanjega trenutka, mainstreama oziroma masovne proizvodnje, če pišemo v ekonomskem jeziku. Obenem pa se zavedajo, da morajo slediti svoji strategiji in tako odpirati vrata na nove trge. Lahko rečemo, da brez prepletanja strategije in trenda skoraj ne moremo.

Iz opredelitve trendsetterja vidimo, da je to nekdo, ki vpliva na potrošnjo, izbiro ljudi. Na to vplivajo poleg medijev tudi blogerji in različni mnenjski voditelji. Ta vidik trendsetterja je treba pogledati še $s$ kritične perspektive. Walter (2008) je podal kritiko družbe, ki je postajala (in je še danes) družba podob, s čimer pa se izgublja bistvo stvari.

BI: »Zagotovo, postali smo visoko estetizirana družba. Vse kupujemo z očmi. Pri hišah so ljudje malo bolj konservativni, ampak, kot sem že rekla, to se spreminja. Ti, ki prihajajo k nam si želijo drugo obliko. Definitivno gledamo z očmi, saj je vsa popularna kultura temu podrejena. To je tisto o čemer sem govorila. Navajeni smo na neke oblike, ki so nam zanimive, ki so v trendu. In enostavno spustimo nekaj, kar mogoče ta trenutek ni tako trendovsko in je ravno tako odlično oblikovano. Je vse v zlatem rezu. Če je dober dizajn. Je tako bom rekla, so ljudje, ki prepoznajo timeless design. Tisto potem ostane. Je pa definitivno, če delaš za ljudi si definitivno trgu podrejen. Se jim nismo toliko podredili, da bi delali masovno gradnjo, malo se pa moraš.«

V podjetju D vidijo trend kot nekaj, čemur je treba slediti. Moramo poudariti, da na izdelke podjetja $\mathrm{D}$ ne vplivajo sezonski trendi, vendar kljub temu opažajo neke trende, ki se pojavljajo.

Tako pravi oseba $\mathrm{D}_{4}$ : $\gg$ Mislim, da v naši branži ni 'playerja', ki bi lahko rekel, oblikovanje pa nič ne pomeni. To je isto, kot da greš delat konfekcijo in rečeš, da te moda ne briga. Ne vem, kdo bi preživel. Če so poleg te funkcije osvetlitve še druge, lahko vzamemo kot pohištvo, je del prostora, je vedno del dizajna. To negirati je tek na kratke proge ali pa se hitro konča. Smo primorani.«

Obenem se osebe v podjetju ne le zavedajo, da obstajajo trendi, temveč so tudi seznanjene z njimi. Tako jih opišejo:

- oseba D4: »Če smo že pri oblikovanju verjetno neki trendi obstajajo. Trenutno, vsaj po mojem občutku, so okrogline, okrogle luči ...«, 
- $\quad$ oseba D2 $\gg$ Te fluidne oblike so in ...«,

- oseba D4: »In krivine. V to je branža že šla. Je treba takoj pristopiti in nekje začeti razmišljati, da bomo morali to delati. Se pravi, obstajajo neke usmeritve.«

Kot lahko razberemo v tej točki, nekim trendom, ki narekujejo obliko izdelkov, podjetje sledi in ni tisto, ki jih ustvarja. Povedali so tudi, da se ti trendi glede same oblike ne spreminjajo veliko. Se pa zavedajo, da je potrebno nenehno ustvarjanje novih stvari.

Oseba D I pravi: »Slabo je, če te drugi prisilijo. Si zaspal.«

Povedo, da so veliko bolj podvrženi spremembam, trendom, spremembam na področju tehnologije.

Oseba $\mathrm{D}_{\mathrm{I}}$ : »Tehnologija se spreminja. Delamo take izdelke, ki so dokaj nevtralni. Dekorativci so aktualni leto dve, ko se pojavi izdelek, je povsod. Na primer od Toma Dixona. Že grejo ven. Sedaj so ti s špagami ... Tako da je to takrat in, in je konec. Mi smo pa trajno oblikovani, da ni tako podvrženo modi ali trendom. Še vedno se tehnologija spreminja na par mesecev, ko je treba posodabljati. Ni pa treba prav vsega.«

Oseba $\mathrm{D}_{3}$ opiše trend kot nekaj kratkoročnega. »Zame kot inženirja je dizajn moda. Zato je tak odnos, kot je med nami, arhitekti in dizajnerji, v drugem načinu razmišljanja. Jaz to vzamem kot modo, ne zato, ker je on nekaj manj. Kaj je meni lepo, vem jaz. Katero vino mi je dobro, vem jaz. In on lahko da ne vem kakšno zgodbo zadaj, če mi je všeč. In isto je za svetilo in nek top svetovni ali nekdo iz Mirna zriše. Oni so pa tisti, ki sledijo tistim trendom, neki vodji in potem mi rečemo ja ali pa ne, kakorkoli.«

Vidimo lahko, da so lahko trendi bistven dejavnik, ki vpliva na organizacijo. Tako D4 pravi: »Že led je kar problematičen. Tako hitro gre razvoj naprej, da se generacije menjajo na pol leta. Ne moreš nabavit zaloge, ker si čez pol leta zastarel.«

Težave, ki sledijo hitremu tehnološkemu napredku, ki je posledica nekega trenda v panogi, opiše oseba $\mathrm{D}_{3}$ : »Učinkovitost posamezne ledice se blazno povišuje, prav tako tehnologija izdelave. Poleg tega imamo še led, ker je nova tehnologija ni standardov. Vsak proizvajalec ima svoj način pritrditve, priklopa. Včasih je vsaka žarnica od vsakega proizvajalca pasala v grlo. Zdaj moraš z vsakim grlom spremeniti še vse ostalo, karikirano ker je nova tehnologija in še ni stara. Saj čez 50 let bodo to delali, ampak saj standardi morajo biti nekako. Zaenkrat je naporno.«

Vidimo, da težko rečemo oziroma omejimo trende zgolj na samo obliko izdelkov, saj lahko tehnološke spremembe prav tako pripeljejo do organizacijskih sprememb. Podobno Desserti in Rizzo (2014) postavita inovacije v središče trikotnika kulture, oblikovanja, inovacije. Vidimo, da so 
lahko inovacije lahko velika gonilna sila in nosilec sprememb v organizaciji, na trgu. Obenem lahko vidimo, da težko ločimo tehnološki in oblikovalski del procesa oblikovanja produkta, kar Julier (2014) poimenuje oblikovanje pod in nad linijo.

V nasprotju s podjetjem $\mathrm{D}$, kjer je oblikovanje izdelka manj podvrženo spremembam, trendom, je podjetje $\mathrm{C}$ tem spremembam podvrženo $\mathrm{v}$ veliki meri, kot vidimo v nadaljevanju, sezonsko.

Oseba CI ta vidik trenda opiše: »Ključno, ker je veliko pozornosti na dizajnu. Da je vsako leto update, korak naprej. Da smo v trendu. Če bi želeli imeti interne, nekoč smo jih imeli interne grafike. Ampak smo se odločili za outsourcing. Mi smo v smučarski industriji in imamo izjemne oblikovalce. Ekipa, $s$ katero boste govorili, ima izjemen in konceptualen element, da pretvori idejo $v$ realizacijo. Vendar se moramo zavedati, da smo zaprti v zimsko industrijo. Agencija pa dela dva, tri, štiri mesece za nas. Istočasno dela za mnogo drugih industrij in ima bistveno večjo širino kot mi. Zato vidimo pomembnost agencij tudi kot neki zunanji faktor, ki nas kdaj usmeri. Pomembno je tudi dejstvo, da imamo dolgoletne partnerje. Delamo z Gigo Design in Sonda Design studiem iz Hrvaške, oba sta desetletna partnerja. Mi verjamemo, da se še niso izpeli. Tudi sami delajo za to, da imajo nove in nove sodelavce. Tudi ni samo ena oseba zadaj in samo ena oseba dela dizajn. Da nam zagotavljajo širino, nas poznajo, vejo kaj je Elan. Tudi oni rečejo, nov oblikovalec je naredil, samo vidimo da ni čisto, to je Rossignol. Ne bomo šli v to smer.«

O hitrosti sprememb in trendov govori tudi delavec $\mathrm{C}_{2}$ : $\gg \mathrm{Nisem} \mathrm{sez-}$ nanjen. Itak imamo vzorce naredimo, in ko je nova kolekcija, novembra delamo že naslednjo sezono, in ko bo vse, se dobimo dol v show roomu in razstavimo in vsak od vodij, oblikovalke in razvoj pove: če bi popravili to, se to ne vidi, in skupaj potem najdemo rešitve za redno proizvodnjo, da bo lažje.«

Kot lahko vidimo, se oblikovalski trendi tako hitro spreminjajo in so odvisni od velikega števila dejavnikov, industrij, da v podjetju težko sledijo vsemu. Vendar, se zavedajo, da imajo tudi svoj slog, izraz, ki ga lahko razumemo kot nekaj stalnega. Podjetja skušajo oboje (slog in modo) usklajevati in na nek način kljub hitrim spremembam graditi identiteto in prepoznavnost. Tako lahko trend povežemo z zunanjimi spremembami, ki se dogajajo na trgu, in strategijo kot notranjo dimenzijo. Če to prevedemo v jezik mode, potem je ta slog, neki trajni element, del strategije, del identitete podjetja, kar morajo subtilno vgrajevati v nove trende. 
Tudi v tem podjetju lahko opazimo, da se spremembe, trendi dogajajo nenehno in da sta tehnološki in oblikovalski del v smislu zunanje oblike povezana.

Oseba $\mathrm{D}_{2}$ pravi: »Smučarija je postala čisti kič. Vsako leto nov komplet. Vsako leto kolekcijo zamenjamo. Nič ne stane, kalup je isti, dizajn se spremeni. Za naše delavce, za naju. Ravno se navadiš ene kolekcije in ene tehnologije, naslednje leto se komplet vse spremeni. Mi ne delamo dve sezoni istega dizajna.«

Vidimo lahko tudi, da je trend, hitro sledenje, povezan celo $s$ kičem. Pri tem je treba povedati, da Binkley (2000) ne vidi kiča v splošnem slabšalnem pomenu, temveč kot odsev današnje družbe, kjer je osebna svoboda velika in posameznik nenehno ustvarja lastno identiteto.

Kot vidimo, se vsa podjetja, v različnih panogah srečujejo s pojavom trenda, naj bo vezan na zunanjo obliko ali tehnološki del izdelka. Vsi vidijo trend kot dejavnik, ki prihaja s trga, od zunaj, kjer je nekdo, ki trend ustvari, narekuje. Odzivi podjetij so različni, odvisni so tudi od panoge, v kateri delujejo. Podjetja, kjer so cikli krajši, morajo tem slediti hitreje, podjetja kjer so cikli daljši, počasneje. Temu sledijo tudi tehnološke spremembe, spremembe v organizaciji in proizvodnji. Glede na velik vpliv, ki ga trendi imajo, tega vidika ne moremo kar zanemariti. Tega se zavedajo tudi podjetja. Obenem lahko rečemo, da je za spopadanje s trendi in spremembami potrebna strategija, strategije. Torej lahko rečemo, da sta trend in strategija obvezno povezana elementa, ki prihajata iz različnih okolij. Trend je vidik trga, strategija vidik organizacije. Spreminjanje trendov je povezano s spreminjanjem strategije podjetja. To je mogoče na dva načina (Ravasi in Lojacono 2005):

- hitro inoviranje in spremembe $\mathrm{v}$ tehnologijah,

- postopno spreminjanje $\mathrm{z}$ dolgoročno vizijo.

Oba avtorja poudarjata strateški vidik prenove podjetja in se sklicujeta na raziskave, ki kažejo, da ni ene same pravilne poti in strategije, o kateri bi se managerji lahko odločali. Ker je poti več, je pomembno gledati, kako strateška prenova zrelega podjetja postane dolgoročen projekt, ne pa kratkoročno spreminjanje konfiguracije podjetja.

\section{Strategija}

Ko oseba A2 govori o strateški usmeritvi podjetja, pravi: »Predvsem hočemo naprej poriniti izdelke, ki imajo dodano vrednost za uporabnika.« Te opredeli: »To so naši paradni konji, s katerimi želimo pokazati, kaj znamo narediti.« 
Kot lahko vidimo, želi podjetje na dolgi rok graditi neko prepoznavnost na trgu, lahko rečemo tudi identiteto, ki je za preživetje potrebna. $\mathrm{K}$ temu vidiku identitete lahko dodamo tudi širši kulturološki pogled, ki pravi, da je identiteta del kulture. V strateško pomembnem izdelku so vgrajene vrednote podjetja.

O izgradnji identitet oseba A I pripoveduje: »Verjamem, da ima SOF dobre zgodbe. Mislim, da je to 'bulshit'. Iskrene zgodbe ostanejo. To je razlika, ali je dobra ali iskrena. Pač hočemo narediti iskren produkt. Vedno ko delamo, je ideja v tem, da je produkt iskren. Da neke vrednote, ki jih imamo v viziji, strategiji podjetja zapisane, tako kot vidimo, da bi morali delovati, da se to tudi izraža skozi produkt.«

Vidimo lahko visoko raven razumevanja gradnje znamke, prepoznavnosti na trgu, znamčenju. Če so v izdelek vgrajena čustva in iskrene vrednote, potem se porabniki raje odločajo zanje, pravita Harris in Chernatony (200I). Kot lahko vidimo, oseba A I verjame, da ni dovolj biti dober, temveč mora biti za tem iskrenost. Pri razmišljanju o iskrenosti oblikovanja lahko uporabimo opredelitve Hesketta 20 I in Buchanana (2008). Kjer je pravo oblikovanje tisto, ki ima vgrajene vrednote. Se pravi, da je tudi oblikovanje del strategije, da je treba slediti oblikovanju od samega začetka.

Tako A I vidi oblikovanje kot pomemben del dolgoročne strategije.

A I pravi: »Vedno oblikovanje prav namerno razlagamo kot načrtovanje. $S$ tem potem tudi na vse odgovoriš. Načrtuje se ne samo storitve, načrtuje se upravljanje ljudi, čas, in to vse sodi zraven. Dobri oblikovalci se tudi s tem ukvarjajo. Smo imeli en lep primer beatnika ${ }^{2}$, ki je sedaj doživel drugo revizijo. Nenehno razmišljamo o izboljšavah. No, nobene filozofije. /.../ proces je nenehen. Izboljševanje je nenehno. Mi vsi stremimo $\mathrm{k}$ popolnosti. Mi vsi stremimo k popolnosti, /.../ nikoli je ne bomo dosegli, lahko pa delamo na tem. In za mene produkt kot tak nikoli ni čisto dokončan. A ne. Vedno se da še nekatere stvari izboljšati, tehnologije se spreminjajo. Mi smo tam, ravno tako, kaj je dober dizajn. Imeli smo šest lopat, vsaka je bila drugače obrezana. Sedaj imamo narejeno, da so štiri enake in dve enaki. To je v proizvodnem procesu ogromna razlika. Zame je to dobro oblikovanje.«

V nadaljevanju vidimo, da A I pripoveduje o dilemah, ki so enake tistim, o katerih pišeta Ravasi in Lojacono (2005).

Pri tem oseba Ar opredeli oblikovanje kot načrtovanje. Načrtovanje opredeli kot proces in tako se tudi ponovno ustvari povezava z izhodiščno opredelitvijo oblikovanja po Heskettu (201 I) in Buchananu (1998). A 
vendar je v tem zaznati tudi menedžerski pristop. Govori o izboljšavah in tehnologijah in se $s$ tem približa opredelitvi Borja de Mozota (2003) ter Ravasi in Lojacono (2005), ki govori o ključnem dejavniku oblikovanja kot inoviranja.

Če gledamo, kako podjetja ustvarjajo svojo pozicijo, lahko rečemo, da v tem primeru ne gre le za trend, všečno podobo, temveč je v ozadju kompleksen proces načrtovanja, oblikovanja, v katerega so vgrajene vrednote organizacije. Le takšen pristop omogoča podjetju dolgoročen obstoj na trgu.

Podobno pravi v podjetju $\mathrm{C}$ oseba $\mathrm{C}_{\mathrm{I}}$ : $\gg$ Naša vizija je biti najbolj dovršena znamka v športni opremi, ki prenaša tehnične inovacije, ki so podkrepljene z dizajnom. Biti leading brand. Misija, vsi naši produkti so inovativni, inovacije podpira dizajn, vsak produkt je zelo preprost. Innovation, design, simplicity, te tri vrednote poudarjamo.«

Ci jasno opredeli njihove vrednote kot del strategije.

$\mathrm{V}$ podjetju $\mathrm{D}$ se sistem njihovih vrednot $\mathrm{z}$ delovanjem, lahko rečemo, nadgrajuje, kar lahko vidimo tudi v njihovem pogledu na strategijo.

DI : »Eno obdobje je bila kvaliteta. To sedaj ni, to moraš imeti in konec. Tudi z razvojem trga in nas postanejo ene stvari normalne. Dizajn je nekaj, kar mora biti. Se ne sprašujemo, ali je dizajn ali ne. Sedaj iščemo tisto več. Se spreminja.«

Oseba $\mathrm{D}_{3}$ pravi: »Je enostavna stvar. Najpomembnejša vrednota sledi tisti osnovni ideji. Se pravi sodoben in kakovosten proizvod, ne pa nizkocenovni za široke množice. Temu je vse podrejeno od strategije, na začetku do razvoja, dizajna in tudi same proizvodnje. To se tudi od delavcev pričakuje. Zadnji, ki da izdelek iz rok, da je kvaliteten.«

Kljub temu da so kakovost in oblikovanje prepoznani kot samoumevni, jih osebe prepoznavajo kot vrednote in kot take pomembe. Temu je podrejeno vse, procesi, vedenje ljudi, tehnologija. Obenem te vrednote že jasno postavijo izdelek na trg, ga pozicionirajo in nakažejo tržno usmeritev.

Intervjuvanci se zavedajo, da je na trgu težko, in se usmerjajo tudi v druge sestavine delovanja podjetja, kar opiše oseba $\mathrm{D}_{\mathrm{r}}$ : $\gg$ Produkte imajo vsi iste. Ne moreš delati nekih velikih inovacij. Lahko pa delaš celoto. Tako da bomo sedaj največ delali na tem. Smo ravno oddali razpis. Bomo naredili kot inovativno storitev prek spletne strani, kaj vse bo omogočala. Komaj čakam, da mu damo življenje.«

Oseba A I vidi in opredeli strategijo: »Glede na to, da je pri nas dizajn ena ključnih strategij v podjetju, tudi samo strategijo načrtujemo skupaj z oblikovalci, se pravi, z Gigo Designom smo imeli nekaj teh delavnic, v ka- 
tero smer, se pravi neki akcijski načrt. To ni zgolj moja ideja ali ideja podjetja. In je vedno, vedno, poudarjam, dizajn ni samo oblikovanje, ampak načrtovanje.«

Iz navedka lahko vidimo, da v podjetju pristopajo $\mathrm{k}$ strateškemu načrtovanju celostno. Ker je oblikovanje njihova strateška usmeritev, že v proces nastajanja strategije vključujejo tudi oblikovalce.

Dolgoročnost in usmerjenost delno izhaja tudi iz sledečega: $\gg \mathrm{Mi}$ pa tudi opozarjamo na vrednost produkta, zakaj to sedaj sploh zadnja leta, da morajo biti produkti narejeni za dolgo časa. Za mene je tudi dober dizajn nekaj, kar gre iz generacije v generacijo in ohranja neko vrednost. Pa predvsem zelo razmišljamo, kaj se s produktom zgodi, ko se njegova življenjska doba izteče. Se pravi pri stolih, od kar poznam in sem v firmi, nenehno popravljamo in servisiramo, refurbish se temu reče, stole. Raje kot da nekaj novega prodamo. Če je stol dober, če je osnova lesena, se zamenja samo površinski material, vse ostalo se obdrži. S tem je obremenitev na okolje manjša in stroški so manjši in tudi vrednost dalj časa ostane. Tukaj, se mi zdi, imamo še veliko priložnosti v dizajnu.«

Tudi oseba B I vidi oblikovanje kot del strateške usmeritve: »Oblikovanje je del strateške usmeritve. $\mathrm{V}$ poplavi ponudbe nam je to v bistvu glavni focal point, da se od drugih razlikujemo po oblikovanju. Dosti energije gre v dizajn.«

Kot pomemben del strateške usmeritve vidijo oblikovanje.

Oseba Aı: »Zapisano je. Govorimo tudi o trajnostnem načrtovanju v oblikovanju. Vloga oblikovanja je ključna. Gradimo na produktih in seveda vsem, kar mora biti okoli tega. Produkta brez dobrega načrtovanja, storitev pa uporabniške izkušnje v tem itak ni. Tukaj se lovimo kot vsi ostali in se trudimo, da bi neke stvari osvojili, ampak mislim, da brez načrtovanja sploh ni nič. To je neumno vprašanje, jaz včasih vidim oblikovanje strateško. Vse je oblikovano.«

Zavedajo se, da je treba ljudi seznaniti s strategijo podjetja tudi znotraj organizacije. Na tak način se ustvarja identiteta, krepi se kultura, sporočajo se vrednote.

Tudi v podjetju D so zaposleni dobro seznanjeni z delovanjem podjetja in tudi sami pravijo, da to močno olajša delo.

Oseba $\mathrm{D}_{5}$ : »Da bi prav točno ... sicer so te vsakoletne, kjer se tudi bolj govori, in to pove nekaj o tem, kaj se dosega, kaj se namerava, kam se bomo usmerili. Je neki zaključek, se pove, kaj se je dogajalo, kaj se je izvedlo, kam se obračamo, kam bi naprej.«

Lahko rečemo, da je za zaposlene poznavanje usmeritve pomembno. Obenem pravijo, da skozi delo najbolje zaznajo spremembe: 
Oseba Ds: »Skozi delo najbolj, ker vidiš, kaj se spreminja, se stvari naredi.«

Delo in učenje sta postopka procesa kulturalizacije.

Obenem se podjetja zavedajo, da so del okolja z vsemi kompleksnimi problemi, in tudi te rešitve skušajo s trajnostnim načrtovanjem vgraditi $v$ izdelke. Lahko rečemo, da obenem krepijo identiteto podjetja, identiteto zaposlenih s podjetjem in identiteto potrošnika, ki lahko spoznajo podjetje kot inovativno, trajnostno in predano oblikovanju.

A I pravi: »Tudi A2 je oblikovalka in skrbi prav za dizajn management v podjetju, zato in vodilne kadre v to vključiti. Brez zavedanja vodilnih kadrov, ki bi to, kaj oblikovanje pomeni, vedeli, je brez veze. In enako velja z državo, vlado. Če se tam ljudje ne zavedajo, pomembnosti, lahko Cerar desetkrat reče, mi stojimo zadaj, les kot strategija Slovenije, če ti tega ne razumeš, če ne veš, ti nihče ne pove, je nekaj drugega.«

To sovpada s Scheinovo (2004) teorijo, ki pravi, da je za ustvarjanje organizacijske kulture potreben vodja, nekdo, ki ima vizijo in strategijo.

Svojo vizijo izdelka so predstavili z izdelkom, namesto z drago marketinško kampanjo, pravi $A_{I}$ : »In s tem smo predstavili vizijo, kaj si predstavljamo pod oblikovanje.«

Kot pravi Heskett (20I I), je predmet nosilec vrednot. Vrednote pa so del kulture. Ashforth, Rogers in Corley (2010) pa pravijo, da so vrednote sestavni element identitete. Se pravi, da je podjetje svojo strategijo, vrednote, identiteto izrazilo prek produkta. Na tak način se je povezalo s potrošniki.

Vendar oblikovanja ne dojemajo zgolj kot oblikovanja produktov, vidijo ga širše, kot oblikovanje storitev. Takšno opredelitev oblikovanja vidijo tudi nekateri avtorji, Heskett, Juliar.

A I: »Mi pa tudi opozarjamo na vrednost produkta, zakaj to sedaj, sploh zadnja leta, da morajo biti produkti narejeni za dolgo časa. Za mene je tudi dober dizajn nekaj, kar gre iz generacije v generacijo in ohranja neko vrednost. Pa predvsem zelo razmišljamo, kaj se $s$ produktom zgodi, ko se njegova življenjska doba izteče. Se pravi pri stolih, odkar poznam in sem v firmi, nenehno popravljamo in servisiramo, refurbish se temu reče, stole. Raje kot da nekaj novega prodamo. Če je stol dober, če je osnova lesena, se zamenja samo površinski material, vse ostalo se obdrži. S tem je obremenitev na okolje manjša in stroški so manjši in tudi vrednost dalj časa ostane. Tukaj, se mi zdi, imamo še veliko priložnosti v dizajnu. In to je načeloma napisano v briefu.«

$\mathrm{V}$ tem vidimo tudi dolgoročnost in celovitost. Izdelek naj ne bi bil le odraz trenutnega stanja, ampak ima vgrajene neke trajne vrednote, ki 
gredo iz roda v rod, in si ga ljudje želijo ohraniti. Lahko bi rekli, da so del kulture.

Podobno vidijo razvoj nadaljnje strategije v podjetju D, kjer Di pravi:

»Produkte imajo vsi iste. Ne moreš delati nekih velikih inovacij. Lahko pa delaš celoto. Tako da sedaj bomo največ delali na tem. Smo ravno oddali razpis, ampak bomo naredili kot inovativno storitev prek spletne strani, kaj vse bo omogočala. Komaj čakam, da mu damo življenje.«

Oseba D4 pravi: »To je podpora arhitekturi. On je podpora za prodajo. Ne prodaš svetilke, ampak prodaš rešitev. To je naslednji korak pri ... eden od naslednjih ključnih faktorjev poleg dizajna. Uporaba sodobnih tehnologij in komponent, ekološki del svetilke, ta četrti faktor, ključni faktor za razvoj podjetja na trgu so zahteve. Ne samo lepe, še cela podpora.«

Oseba $\mathrm{D}_{3}$ : $\gg \mathrm{Da}$ ne prideš na razpis z desetimi drugimi ponudniki, kitajskimi, preprodajalci iz Ljubljane in tretjim, ki ti določijo ceno in število svetilk, ampak da je par nivojev višje. Že lastniku, arhitektu, projektantu ponudiš rešitev.«

Se pravi oblikovanje, produkt podjetja, vidijo širše, tudi kot storitve in njihovo oblikovanje.

Di: »Predvsem, kaj rabimo. Za vse ne rabimo briefa. Za katalog ga nismo naredili. Za spletno stran smo ga naredili. Za katalog to hočemo doseči in je bila rešitev. Tako smo delali sekvenčno področja image strani, predstavitev stran, kazala, so bili neki mini brifi za področje.

Za spletno stran rabimo natančen brif in rešitve, ker bo kompleksen projekt in ga moramo dobro zastaviti, da ga lahko hitro speljemo. Ga moramo v šestih mesecih realizirati.«

Vidimo pa tudi, da je pomemben brief kot del načrtovanja, projekta, produkta, kjer so zapisani cilji, usmeritve, nekakšna strategija.«

Se pravi, strategije ne razumemo le na strateški ravni, ampak vidimo, da je potrebna na vsakem koraku, da se preveri, ali je v skladu z vrednotami podjetja.

Bowman in Ambrosini (2007) pravita, da je za ustvarjanje dodane vrednosti bolj kot strategija pomembno definiranje vrednot. Zato tudi v nalogi ne opredeljujemo različnih nivojev določanja strateških aktivnosti, omenjamo pa brief kot enega pomembnih elementov v procesu oblikovanja, saj pomaga določiti in opredeliti problem, zahteve in vrednote.

Pomembnost briefa kot orodja, ki lahko pomaga na vseh ravneh odločanja, je izpostavila oseba Di: »Se pravi, potem je ravno za ta brief, za spletno stran je zanimivo, da vidiš, da lahko doziraš inovativnost na različna področja. Recimo spletna stran ne rabi biti inovativna v komunika- 
ciji. Mora biti inovativna v storitvi in produktu. In na teh področjih lahko ustvarimo nekaj, kar še ne obstaja, drugje pa ohranjamo in izboljšamo. Ta se mi je zdel super, da lahko celovito in globinsko vidiš, kam kaj dati, kaj hočeš , kje se hočeš razlikovati od konkurence. Potem je dosti, prav pri tem področju briefa, kako sploh zaznati problem. Dostikrat, ko nekaj delaš, razmišljaš in dobiš rešitve. Recimo brief za spletno stran, je bilo lažje dobiti rešitve, preden smo zaznali problem. Potem smo šli najprej do rešitve in potem do tega, kak je problem zadaj in ko prideš do problema, lahko prideš do drugih rešitev, kot če bi z druge strani začel. Take, praktične stvari.«

Ta pogled na oblikovanje kot na del strateške, bistvene usmeritve se odraža tudi skozi pogled nanj s finančnega vidika, kjer oblikovanja ne vidi kot strošek, temveč kot investicijo. Pri tem razume investicijo kot nekaj, kar se v času povrne. Različne empirične študije sicer niso potrdile velikega vpliva oblikovanja na poslovno uspešnost podjetja (Dickson idr. 1995; Perks, Cooper in Jones 2005; Roy in Potter 1993; Roy in Riedel 1997; Swink 2000 po Chiva in Alegre 201 I). Predvsem vidijo oblikovanje kot del organizacije in pravijo, da je uspešnost investicij odvisna od učinkovitosti oblikovanja, kar pa je predvsem menedžerski pogled. Kljub temu sta Chiva in Alegre 20 I I ugotovila, da je predvsem pomembno, kako se sredstva v oblikovanju porabljajo, in ne le višina tega zneska. Tudi oni poudarjajo, da na strateško uspešnost oblikovanja kot investicije bolj kot sama višina sredstev vplivajo mehki dejavniki organizacije, kultura in identiteta.

A I: >En dober stavek je, ki ga skoz poudarjam. Oblikovanje je investicija. To ni strošek. Tukaj je samo razlika. Najprej so razrezali razvoj, oblikovanje, ker so ga razumeli kot strošek. Če bi ga razumeli kot investicijo, nekaj, kar zagotavlja, da bodo delali dober dizajn in vse, kar pride za tem, ti sploh omogoča, da podjetje preživi. Vsi gledajo, kaj ljudje potrebujejo. Ampak to sprašujejo ljudi, ki nimajo pojma o dizajnu. Jaz pravim, da je treba vprašati arhitekte in oblikovalce, kako si oni prestavljajo družbo in okolje. Ker je to del njihovega življenja, o tem so razmišljali.«

Kljub temu da so nekatera podjetja majhna, se zavedajo, da je treba ne le oblikovati, temveč tudi upravljati, in imajo prisotne formalne pristope $\mathrm{k}$ udejanjanju strategij.

Ar: 》 Tudi A2 je oblikovalka in skrbi prav za dizajn management v podjetju. Brez zavedanja vodilnih kadrov, ki bi to, kaj oblikovanje pomeni vedeli, je brez veze. In enako velja za državo, vlado. In če se tam ljudje ne zavedajo pomembnosti, lahko Cerar desetkrat reče, da oni stojijo za- 
daj. Les kot strategija Slovenije, če ti tega ne razumeš, če ne veš, ti nihče ne pove je, nekaj drugega.«

Upravljanje strategije vidijo predvsem kot obveščanje in izobraževanje o pomenu oblikovanja. Pri snovanju strategij sodelujejo z Gigo design, ki je oblikovalska agencija in je imela dve leti projekt kompetenčni center za dizajn management.

V nasprotju z njimi pa drugo podjetje ne sodeluje z zunanjim svetovalnim podjetjem. Pri njih nastajajo strateške usmeritve individualno.

$\mathrm{B}_{1}$ pravi: »Ja, imamo. To bi moral $\mathrm{B}_{2}$ več povedati. On je glavni strateg. Predvsem vedno mora biti nekdo, ki ima vizijo. Je nimamo vsi. Nekdo je dober izvršitelj del, nekdo, na primer Tomaž, je vizionar. On že dve leti vnaprej neke trende prepozna. Ne vem, kako, ampak jih. Konstantno razvijamo neke stvari. Že pet, šest, sedem let nazaj smo začeli z majhnimi objekti, ki so se šele sedaj razpasli.«

Tudi v tretjem podjetju, ki je sicer veliko, sloni strategija na srednjem managementu, ki ga koordinira ena oseba ob sodelovanju z različnimi skupinami: »Tudi če se odločimo za novo strategijo, novo smer, produkte, jih pokličemo zraven. Imamo delavnice in presojamo, smo odprti in si dovolimo reči, to pa ni v redu. Mi imamo svoje izkušnje, oni svoje, dajmo se pogovarjati na enakovredni ravni.«

Se pravi, da se pojavljata dva pristopa k strateškemu načrtovanju. Eden je kot rezultat teamskega dela (Kaplan in Norton 2008) in drugi individualen, kjer obstaja ena oseba, vizionar. Ta vidik se sklada s pogledom Scheina (2004), ki pravi, da je za snovanje strategije potreben vizionar, ki usmerja podjetje, gradi korporativno kulturo. Ne glede na to, kdo snuje strategijo podjetja, so osnovna vprašanja, na katera morajo pri snovanju odgovoriti, kdo smo in kam gremo (Kaplan in Norton 2008). Torej morajo najprej opredeliti svojo identiteto, kdo smo, kam gremo, kot jo opredeli Olins (2002).

Kot smo lahko razbrali iz analiziranih intervjujev, je oblikovanje pomemben del strateške usmeritve obravnavanih podjetij. Pri tem je pomembno poudariti, da je treba pri tem uporabiti opredelitev oblikovanja širše, kjer gre tudi za oblikovanje procesov (Bjögvinsson, Ehn in Hillgren 20I2). Če pa gledamo ožji vidik, kjer gre samo za oblikovanje produktov, potem lahko rečemo, da je za tri podjetja od štirih oblikovanje strateško pomembno, pri enem podjetju pa dajejo skoraj večji poudarek tehnološkim inovacijam, pri čemer ne zanikajo pomena oblikovanja oziroma ta pojem uporabljajo širše in ga vgrajujejo v vse dele organizacije. Tudi na tovrstno načrtovanje gledajo z oblikovalskega vidika. 
Tako smo zajeli v intervjujih tisti dve ključni dimenziji, ki ju Ravasi in Lojacono (2005) opisujeta kot različna pristopa oziroma dimenziji prenove strateške usmeritve oziroma strategije podjetja. Eno od podjetij v raziskavi gre $\mathrm{v}$ smeri postopne prenove in ima vizijo, dolgoročno usmeritev, ki sledi svojim ključnim programom/izdelkom. Preostala tri podjetja so vgradila $\mathrm{v}$ procese nenehno inoviranje in spremembe $\mathrm{v}$ tehnologijah in $\mathrm{s}$ tema dejavnikoma osvajajo hitro spreminjajoče se zahteve trga. Vsi so izpostavili oblikovanje, tehnologije. Dve podjetji sta temu dodali še zeleno, ekološko usmeritev in dve podjetji enostavnost.

Intervjuvanci poudarjajo, da je v njihovih produktih ne glede na trende vgrajena njihova identiteta, kdo so, kaj so in kam gredo. To se odraža pri izbiri materialov, načinu delovanja, komuniciranja in delovanja.

\section{Kultura oblikovanja}

Pojem kulture oblikovanja bomo pogledali s treh vidikov, ljudje, inovacije in FFF (form follows function), se pravi povezave med funkcijo in obliko. Vidik ljudje zajema, kako ljudje dojemajo oblikovanje, oblikovalske izdelke, s tem se po Juliarju kaže vidik potrošnje, stopnja ozaveščenosti. Inovacije kažejo na vidik proizvodnje, se pravi tehnološki okvir zmožnosti proizvodnje, pri form follows function pa gre za stari Sullivanov koncept oblikovanja, ki obsega oblikovanje kot celostni vidik oblikovanja, se pravu po Juliarju (200I) nad in pod linijo.

\section{Inovacije}

Inovacije razumemo različno, posebno v oblikovanju pogosto ne gre za odkrivanje nečesa popolnoma novega. Vedno se gradi na obstoječem. O tem govorijo de Oliveira idr. (2016), ko pravijo, da so inovacije nenehen proces zbiranja znanja, specifičnega za podjetje, na katerega vplivajo nenehna razmerja med podjetji v panogi in drugimi organizacijami. Ko razmišljamo o inovacijah kot o nečem, kar vpliva na družbo, pravi Denning J. (2004), so inovacije tiste spremembe, ki vplivajo na družbo in spremenijo vedenje, invencije pa vidi kot spremembe brez vpliva na družbo ali okolje. Inovacije so pomembne tudi, ker jih v modelu kulture oblikovanja Desserti in Rizzo (2014) vidita kot gonilno kolo, ki poganja odnose med proizvodnjo, potrošnjo in oblikovanjem. Likar, Križaj in Fatur (2006) razlikujejo inovacije in invencije. Poudarjajo, da je inovacija nova zamisel, nov izdelek, torej nekaj novega, kar je sprejeto na trgu.

$\mathrm{V}$ nadaljevanju bomo pogledali inovacije $\mathrm{v}$ podjetjih prek treh vidikov, kot o njih govorijo intervjuvanci. Pripovedovali so, kako so znamče- 
ne, kako vplivajo na procese in kako vplivajo na kulturo, učenje kot element tvorjenja kulture.

Oseba Ci pravi: »Kot samo oblikovanje močno prištevamo k oblikovanju tudi inovacije. In ravno inovacije skupaj z dizajnom nam zagotavljajo konkurenčno prednost, razlog, zakaj Elan in ne kdo drug na trgu. To je zelo jasno prepoznano tudi glede na analize, ki jih delamo, vprašalnike za industrijo, questionary service, je to jasno priznano s strani trgovcev, da smo innovation leader v industriji, in to nam zagotavlja obstoj.«

»Samo v Avstriji, kjer je veliko domačih znamk, smo že s tega vidika brand. Tudi v Franciji, to sta pa dva največja trga tudi zaradi turizma. Že to, da rastemo vsako leto v Franciji, kaže na to, da gremo v pravo smer.«

Inovacije so zagotovo eden ključnih dejavnikov zagotavljanja konkurenčne prednosti. Aaker (2007) pravi, da inovacija nič ne pomeni, če je podjetje ne trži ustrezno. Ostane le invencija, kot pravijo Likar, Križaj in Fatur (2006). Notranji vidik inovacij pa Teece (2010) vidi kot skupek vseh dejavnikov v podjetju, ki delujejo kot celota.

$\mathrm{V}$ tem smislu razpravlja tudi oseba $\mathrm{C}_{2}$ : »En človek ne more izdelka pripeljati do konca. Imamo inovacije, jih mesečno nagrajujemo. Tako da vsak prispeva $\mathrm{k}$ svojemu. Ko naredimo novo kolekcijo, se skupaj dobimo, jo skupaj komentiramo. Sam izdelek nikdar ne visi samo na enem. Samo na oblikovalkah ali samo na tehnični službi. Smo vsi, da pridemo do cilja.«

Oseba $\mathrm{C}_{3}$ : »Tudi najnižji delavci vedo, kaj je dobro, lahko komentirajo. Zapišemo, skličemo sestanek in upoštevamo. Če se da spremeniti, spremenimo, drugače je pa treba tudi kako investicijo narediti. Ker je v vsaki kolekciji 'to pa to', investicijo ali pa v procesih 'to pa to' uštimati. Nikoli ni, da je nov izdelek in da bomo rekli, sedaj ste si ga zamislili in ga naredite. En da idejo, potem pa je treba idejo preučiti, kako jo speljati v procesu. Če bo ta ideja obrodila sadove, je treba 'to pa to' narediti, za tem je toliko stroškov. Časa je malo, mi ga rabimo nekaj, mora vsak na svojem področju speljati. Ne moremo imeti samo ideje. Ne bi prodali smučke.«

Oseba $\mathrm{C}_{3}$ : »Korektni predlog in dobi 37 evrov. Za kakršenkoli. Če je pa to več vredno in smo veliko prihranili, se skliče komisija in on dobi več. Vsako leto prve tri inovatorje nagradimo.«

Kot lahko vidimo v nadaljevanju, ni inovativen le izdelek, temveč se inovira tudi pri procesu pridobivanja znanja. Oseba $\mathrm{C}_{3}$ je razvila sistem usposabljanja zaposlenih, ki zagotavlja kakovost izdelka.

Oseba $\mathrm{C}_{3}$ : »Enkrat letno naredim spremembe. Naredim - najprej sem se naučila narediti vse barvasto, poslikam - eno inventuro. Je vse barvasto označeno. Kar je v plošči rumeno, je tudi rumena škatlica, tako 
ni treba vedeti kode. To sem letos delala 1,5 meseca. Da sem označila vsa delovna mesta, vse zaboje, kjer so notri vijaki, plate. Potem naredimo teste kot v šoli. Vse delavce iz montaže pokličem v pisarne. Potem pišejo test. Vprašanja. Potem vprašanja pred njimi vzamem in gremo skozi še ustno. Najprej je napisal, mu preberem, kaj je napisal, in še zraven povem, kaj ni dobro, kaj je dobro. To mislim, da se je obrestovalo. Vsakega delavca, ko vpeljem novo metodo dela, je obvezno vse barvasto označeno, enostavno. Tako kot za I. razred. Ne sme biti za več. Potem pa še testirati, kaj misli. Napisati ne zna, samo da vsaj pove. Tako gre, da prideš s kvaliteto, da si konkurenčen.«

Inovacije segajo onkraj golega tehničnega razumevanja. Zavedajo se, da inovacije pripomorejo $\mathrm{k}$ boljši kulturi in boljši izkušnji uporabnika. Torej so vezane tudi na trg in kot take znamčene. Kot pravi Aaker (2007), inovacija sama po sebi nič ne zagotavlja, če ni kot taka prepoznana. Podjetje C je v panogi vedno bolj prepoznano kot inovativna znamka.

Oseba $\mathrm{C}_{4}$ : »Ja, to tudi ni oblikovanje, samo redizajn, ampak gre za inovativno rešitev, ki daje ne le novo obliko, ampak na trg nov in inovativen izdelek, ki pripomore k boljši kulturi bivanja ali pa boljši izkušnji uporabnika.«

Tudi v podjetju A vidijo inovativnost kot del njihovega delovanja. Morda ne v samih tehničnih rešitvah, temveč v izbiri materiala.

A I pravi: »Tako da smo potem v to smer nadaljevali, ker material je pač nekaj novega, čeprav je že kar nekaj izdelkov iz filca videti. Ampak še vedno je čisto drugače od navadnega stola, openjenega. Pena ni najbrž do okolja prijazna. Tukaj pa je 'upcycle'. To je zelo pomembna nota. Tako smo prišli do tega materiala. In bomo verjetno tudi še vztrajali pri drugih izdelki, ga kam vkomponirali. Ker je zelo trpežen, kakovosten plus ta nota recikliranja, družbene odgovornosti.«

Tudi pri njih je inovacija znamčena. In ne le to, v tem so vgrajene njihove vrednote, ki konstruirajo njihovo kulturo, obenem pa so del znamčenja in identitete na trgu.

V podjetju D oseba Di vidi inoviranje širše kot oblikovanje zgolj produktov: >Prej se je inoviralo kose, produkt, storitev in pogosto niso bili najbolje povezani med sabo. Če povežeš posamezne dele in celoto, potem je vse bolj učinkovito.«

Di tudi vidi veliko priložnosti za inoviranje, ki gre onkraj inoviranja tehnologije izdelka: »Že baza podatkov je tudi tak problem. Ker glede na to, da se tehnologija hitro menja, ne moreš vzdrževati na infokatalogu, ceniku, internetu, da spremeniš na enem mestu in se ti povsod pozna, dosti je tega, da si uredimo in ima operativo rešeno.« 
$\mathrm{V}$ nadaljevanju tudi pojasni, da so pregledne in ažurne informacije ključnega pomena, saj se tehnologija spreminja mesečno.

Zanimivo je, da se podjetje D načrtno ukvarja z upravljanjem inovacij tudi s finančnega vidika. Pri tem je tudi prisotno zavedanje, da mora biti inovacija ne le finančno smiselna, temveč strateško pomembna, v skladu $s$ trenutno strategijo.

DI: »Ves čas novo ... je pa res, da ni treba ves čas vse inovirati. $S$ tem lego podjetjem lahko izboljšaš področje. Inovacija je draga, je čas, so ljudje, testiranje, napake. Vse. Moraš dobro vedeti, kam jo dati, kje je najbolj pomembna, da se zgodi.«

$\mathrm{V}$ tem podjetju se odvijajo inovacije na vseh nivojih in tako oseba $\mathrm{D}_{5}$ pravi: »Spodbudi te, da lahko kaj spremeniš. Tudi sebe na boljše. Največ je, da si olajšaš delo. Iz proizvodnje je največ teh predlogov. Luč ostane taka, kot je, pero je lahko cenejše, se da, v proizvodnji se da še dosti popraviti.«

Lahko vidimo, kako inovacija vpliva na individualnem, osebnem nivoju. Lahko bi rekli, da je inoviranje del kulture podjetja, ki se zaveda, da morajo biti spremembe nenehne. Kajti obstane lahko le podjetje, kjer so inovacije sestavni element kulture (Kotter in Heskett I992, Likar, Križaj in Fatur 2006).

Oseba $\mathrm{D}_{3}$ : >Že samo predlog drugega vijaka je neko sodelovanje, ki je ... ne vem, pač kot sem rekel, fantje probajo, je v redu ... če ni v redu, povejo. Morda daš s tistim, ko predlagaš, tudi njim idejo za naprej. Če noben ne drgne tisto, da vemo nekaj tako, dajmo nekaj zamenjati, spremeniti, se ustavi na določeni točki. On da en vijak in pač bomo vsi šravfali, čeprav je lahko brezveze. Če en reče, ali lahko lažje, mu da misliti. Tisti vijak, ki si ga predlagal, drugi bo razvojnik bo videl, bo dvakrat šel v roke, to bi tudi lahko.«

Vidimo, da ima spodbujanje inovacij, sodelovanje ljudi pozitivne učinke. Ne le da se lahko ustvari izboljšava na izdelku, temveč se omogoči ljudem sodelovanje, tako da so vsi člani organizacije seznanjeni s kulturo organizacije in se lahko aktivno izražajo in sodelujejo.

Zagotovo lahko rečemo, da so inovacije pomemben dejavnik organizacijske kulture. Vsebujejo element učenja novega, kar pa je sestavina procesa socializacije, kulturalizacije in zato kot take tvorijo kulturo oblikovanja v organizacijah. Lastnost inovacije je, da mora biti družbeno sprejeta oziroma imeti vpliv. Kot taka je del kulture in vpliva na kulturno okolje. Iz primerov smo lahko videli, da inovacija ni vezana le na sam izdelek, temveč je vezana tudi na izvajanje, oblikovanje storitev. Tudi je tre- 
ba razumeti opredelitev oblikovanja in tako lahko izpeljemo, da je inovacija eden izmed elementov kulture oblikovanja.

\section{Ljudje}

V intervjujih se je izkazalo, da so komunikacija, sodelovanje in znanje pomembni. Intervjuvanci so jih pogosto omenjali. Sestavni del komunikacije je tudi jezik. Saleclova (20 I ) pravi, da ima jezik moč, da vzpostavlja razmerja moči, in ni namenjen le komuniciranju in posredovanju informacij. Komunikacija v podjetjih je različna in je odraz nevidne strukture odnosov znotraj podjetij in tudi razmerij moči. Jezik je del kulture podjetja, ki se odraža v posebnih izrazih, metaforah in podobnem. Pozitivno povezavo med jezikom in kulturo potrjujeta tudi Luo in Shenkar (2006).

$\mathrm{V}$ nadaljevanju analiziramo odnose med zaposlenimi v podjetju, kot jih vidijo intervjuvanci, kako ti odnosi po mnenju intervjuvancev vplivajo na oblikovanje, komunikacijo, navsezadnje strategijo. Kot smo videli v pregledu literature, se osebna identiteta in identiteta podjetja prepletata (Ashforth, Rogers in Corley 2010). Identiteta se oblikuje v odnosih z drugimi (Sherwood 1965), zato so odnosi med zaposlenimi bistveni za razumevanje konstruiranja identitete posameznika v organizaciji.

Oseba A2 govori o pomenu zaposlenih v podjetju in pravi: »Bo oseba A I najbrž tudi tako povedala. Tako me je naučila. Vsak zaposleni v podjetju je ta mali del sestavljanke. In kot sem prej rekla, če smo vsi za isto stvar, vsi isto razmišljamo, vsi v isto smer rinemo, potem se lahko nekam pride. Ko enkrat pride do različnih razmišljanj v podjetju, navzkrižij mnenj, se lahko sistem omaje in razpade. Mislim, da zaposleni so podjetje in podjetje, vedno so zadaj ljudje, ljudje so tisti, ki so pomembni.«

Oseba A I poudari: »Kompetenčni center za dizajn management je neki model razvil, to je model, ki temelji na finskem modelu. Od tam smo imeli delavnice, izobraževanja. $\mathrm{Na}$ začetku dizajn management pomeni bolj koordinacijo, logistiko. Mi smo vseeno majhno podjetje, tudi če me imajo za prevelikega idealista, je tako, da moramo biti vsi za. Moja naloga je prepričati, da mi zaupajo, da si zaupamo. Če niso vsi on board, je brezveze. Mi imamo s kakšnim komercialistom probleme, ker ne verjame v izdelek. Kaj pa to delamo, to je brezveze. Kako bo lahko nekdo prodal, če ne verjame. Njena vloga je taka, da oblikovalci razumejo podjetje. Dobre zgodbe, verjamem, da se pišejo takrat, ko je to sodelovanje dolgotrajno. Kolikor te lahko neki hišni oblikovalec omeji, je še zmerom dobro imeti nekoga, ki te razume in zraven nenehno izumlja in sodeluje. Mi vseeno z veliko oblikovalci na tem področju sodelujemo.« 
Lahko rečemo, da je v podjetju A močno zavedanje o pomenu sodelovanja zaposlenih in njegovem prispevku $\mathrm{k}$ uspešnemu delovanju podjetja. Zavedajo se, da so osnova za dobro sodelovanje, skupne vrednote, prepričanja. Šele ko obstajajo skupne vrednote, lahko vsi sodelujejo in gredo v skupno smer.

Oseba A2 poudari: »Raje vprašajte njih. Ampak ... jaz sem samo eden. Moja vloga ne glede na to, da sem lastnik ali direktor, je en glas. Od 24. Se pravi, če se vsi ne strinjajo, kar se je že zgodilo tudi pri kakšni taki odločilni zadevi, se pač tega ne gre. Brez zaposlenih ni nič. To govorim tudi večjim podjetjem, ki so večji, in direktorjem, da če bodo delali težavo tam, kjer je pet evrov višja plača strošek in problem, naj zaprejo. To nima smisla. Že po Maslowu se svoboda začne z neko socialno varnostjo. Se pravi, če ljudje nimajo dati na mizo za jesti in piti, ne morejo biti kreativni. Ne morejo se ukvarjati z detajlom. Ne morejo razumeti koncepta, da hoče nekdo imeti produkt, ki je res narejen perfect. Zato je treba najprej poskrbeti. Ljudje, okolje in potem vse ostalo.«

Podobno vidijo odnose in pomen ljudi v podjetju B.

»Odnosi so neformalni, zaposleni pa zelo pomembni. Če enega člena ni, težko shajamo. Zaenkrat glede na velikost podjetja nismo številke in zamenljivi. Vsak ima svojo funkcijo in ga je težko nadomestiti. Tako je $\mathrm{v}$ majhnih družinskih podjetjih. Funkcije se med seboj zelo prepletajo in težko je en nadomestljiv z danes na jutri. Ta trenutek težko, je tudi ahilova peta manjših firm /.../ zaenkrat smo, tako, če je dovolj dela, smo vsi zadovoljni, če ni dela, smo vsi nezadovoljni. Ker nas je malo, smo vsi odgovorni za količino dela.« (Oseba $\left.\mathrm{B}_{\mathrm{I}}\right)$

$\mathrm{Naš} \mathrm{intervjuvanec,} \mathrm{lastnik} \mathrm{in} \mathrm{menedžer} \mathrm{v} \mathrm{podjetju,} \mathrm{se} \mathrm{zaveda} \mathrm{pomena}$ zaposlenih v podjetju, pri čemer vidi glavno prednost predvsem v enakem razmišljanju. Kot lahko razberemo, je pri tem mišljeno, da delijo enake vrednote. Vrednote pa so del kulture (Schein 2004, Schultz in Hatch 1996, Tellis 2009). Torej je osebi A2 zelo pomembna kultura v podjetju. Učenje je pomemben vidik, ki konstruira kulturo in vrednote.

A2: »Karkoli, kakršenkoli problem je, imamo veliko izkušenih v proizvodnji, ki imajo dolgoletne izkušnje, so delali tudi v Stolu Kamnik, in vedno se gre do njih, kako bi to rešili. Tega ne vem, kaj praviš. Zelo se spoštuje njihovo mnenje in vedno so del razvoja, ker tako smo majhni, da moramo konstantno sodelovati med sabo in pomagati. En zagotovo ne ve vsega. Več glav več ve.«

Lahko rečemo, da se v podjetju B pojavlja koncept učeče se kulture, kot ga opredeljujejo Egan, Yang in Bartlett (2004). To je kultura, kjer je učenje središčni proces. Učenje je pomembno in se pojavlja tudi v kon- 
ceptu učeče se organizacije (Škerlavaj, Štemberger in Dimovski 2007). Oblikovanje je proces, $\mathrm{v}$ katerem se nenehno preučuje in išče rešitve. $\mathrm{V}$ ozadju iskanja in definiranja problema je znanje (Braha in Rice 2003, Shepard 2000, Marsick in Watkins 2003; Egan, Yang in Bartlett 2004). Torej je učenje vidik oblikovanja. Zavedajo se, da ima vsak zaposleni neko specifično znanje, ki je potrebno za uspešno delovanje podjetja in sodelovanje. Zato so vsi zaposleni aktivno vključeni v iskanje rešitev glede na strukturo njihovega znanja.

Vidik komunikacije je za uspešno delovanje pomemben. Proces komuniciranja v podjetju A oseba A2 opiše kot: »Spontan. Kakšni kreativni sestanki so na začetku z oblikovalci, ki dajo svojo idejo, potem pa pride do izpeljave. Potem pa se mi začnemo pogovarjati. Tako da ne bi rekla kaki sestanki, ampak tako spontano.«

Kot smo rekli v izhodišču, jezik ustvarja pozicije moči in ni le sredstvo komunikacije (Salecl 20I2). Lahko rečemo, da sproščena, spontana komunikacija govori o fleksibilni strukturi v podjetju in tako omogoča interakcijo med zaposlenimi.

$\mathrm{V}$ podjetju C pravijo celo, da dobri odnosi med zaposlenimi vplivajo na kvaliteto, učinkovitost. Vidimo lahko, da so neformalni odnosi ključni pri delovanju podjetja.

$\mathrm{C}_{3}$ : »Rekla bi, da odnosi. Ker če so odnosi nekako v redu, potem se da $\mathrm{z}$ lepim odnosom ali s kakšnim pristopom pripeljati stvari do lepšega cilja. Če so odnosi slabi. In komunikacija. Mislim, da je to prvo, kar mora biti. Če to 'laufa', potem prideš do lepega izdelka in rezultata. Če ne 'laufa', potem je veliko nepotrebnega truda, slabe volje, greš nezadovoljen. Če so lepi odnosi, greš v službo vesel in lažje narediš kako nalogo, če ni tvoja in jo znaš. Če so odnosi skrhani in ne v redu, potem pa rečeš, saj to je od drugega, ne prideš do cilja. Je več ur, vsega ... To je meni najpomembnejše.«

Tudi v podjetju A poudarjajo kakovost komunikacije, kar je posebej izpostavila tudi oseba A2: »Trudimo se izobraževati ljudi v tej smeri. Da razmišljamo, da se oblikovanje ceni. Vsi smo vključeni v te procese, koliko je zadaj nekega dela. Mislim, da ljudje počasi razumejo, zakaj ima izdelek neko ceno, zakaj ima visoko dodano ceno, ker razume ta potek, ki je za izdelkom. Mislim, da je kultura kar visoka zaradi tega, ker je tu ta konstantna komunikacija iz izobraževanja v to smer. Za primer je lahko samo beatnik, koliko je dela, da se ga naredi, koliko je razvoja zadaj, koliko vložka, sejmov, vsega, da se ga je pokazalo. Zaradi tega je prišlo do neke cene. In tako morda ta primer.« 
Komunikacijo povežejo $\mathrm{z}$ izobraževanjem, kar izpostavi tudi oseba $\mathrm{C}_{2}$ : »Imamo enkrat letno, na začetku leta, tako bi rekel, prikažemo, kakšni smo bili, kaj bomo letos. To je zato, da so osveščeni. Usposabljanje delamo vsakodnevno, ker je, saj pravim, veliko ročnega dela, med letom se veliko stvari spremeni. Ta smučka ima en laminat in ni ok. Sredi leta naredimo spremembe. Potem pa spet ... ena smučka leva taka, desna taka ... Skozi. Danes je leva desna smučka, levi kalup in desni kalup. Levi material mora v levi kalup, desni material v desni kalup. To je skozi ... ni tako kot včasih, ko so zmetali, pod gasom bili in je bilo vse ok. Usposabljanje je vsakodnevno.«

Kot smo videli v izhodišču, živimo danes v času hitrih sprememb in temu je podvrženo tudi organizacijsko učenje. To poteka hitreje kot kadar koli. Pri tem moramo upoštevati tudi specifike posamezne panoge, saj so proizvodni cikli odvisni od vrste izdelka.

Tudi podjetje D je podvrženo hitrim tehnološkim spremembam, ki se odvijajo na trgu. Oseba $\mathrm{D}_{4}$ je kot eno izmed vrednot izpostavila znanje.

D4: »Dejansko je to to. Na neki način imamo tehnološko dosti zahteven proizvod. To je elektrika, elektronika pa tudi mehanika, in čeprav je tudi mogoče v osnovi neizobražen, ampak tudi dobi izobrazbo v proizvodnji. Je ogromno znanja. Če tamle neka delavka zna zvezati, kaj vem, priklopiti izdelek, to je eno veliko znanje, ki ga včasih ne znamo ceniti. Smatramo kot samoumevno. Nekaj je, ampak tak je ponos. Delam v Intrig. To nekaj pomeni. To je tisto, kar pripomore $\mathrm{k}$ samozavesti. Čutim kot vrednoto.«

Znanje je nekaj, kar včasih spregledamo. Vidimo, da znanje kot vrednota pripomore $\mathrm{k}$ večji pripadnosti podjetju in dviguje samozavest. Če to postavimo $\mathrm{v}$ kontekst kulture, lahko rečemo, da je pomemben element kulture znanje, ki deluje kot kolektivno, mentalno programiranje ljudi (Hofstede in Minkov ı99ı; Criveanu 2015). Reševanje problemov, pri katerem potrebujemo znanje, je del korporativne kulture (Schein 2004; Syafii, Thoyib in Nimran 2015).

Ljudje kot nosilci znanja in veščin so pomembni, saj se to odraža tudi pri kakovosti izdelka, ki je ena izmed vrednot podjetja. To poudarjajo tudi zaposleni, ki so s proizvodnjo tesno povezani.

$\mathrm{D}_{3}$ to opiše: »Ja zelo. Kar tudi potem v feedbacku slišimo, ni kar en šrauf, če takega not vtakne, ampak se zelo zelo pazi na, se pravi, pravilnost izdelave, porabo materiala itd. Moj občutek je, da ni šlamparije, ki je pri vseh podjetjih, oziroma jo je precej manj.« 
D2: »Pri delavcih v proizvodnji se ne ukvarjamo s samo kontrolo. Tukaj ni nekih kontrolorjev, ki bi spremljali. Vsak mora imeti odgovornost, da opravlja svoje delo.«

$\mathrm{D}_{3}$ : »Ker vsi vejo, da delamo visoko cenovni oblikovno sodobni izdelek, se moraš vživeti v uporabnika tega proizvoda.«

Vidimo, kako je posredovanje vrednot, komuniciranje pomembno, da se doseže kakovost kot eden izmed ciljev podjejta. Obenem pa lahko rečemo, da participacija in dobra obveščenost, dobri odnosi v podjetju pripeljejo do višje samozavesti (Pierce in Gardner, 2004), ta pa pripelje do višje samokontrole. Ker so načini delovanja del kulture (Criveanu, 2015), tako vse skupaj zaokroži in vodi k nenehnemu napredovanju in izboljševanju. Zavedajo se, da izobraževanje in komuniciranje pozitivno vplivata ne le znotraj podjetja, temveč tudi v zunanjem okolju. Tako kupci spoznavajo izdelek in razumejo, zakaj ima neko ceno. Lahko rečemo, da je znanje, ki je za izdelkom, del strategije. Obenem, ko tudi kupci prepoznajo to znanje kot vrednoto, se začne postopek spreminjanja kulture. V tem primeru govorimo o dvigu kulture oblikovanja. Rečemo lahko, da je znanje kot ena od sestavin procesa oblikovanja pomembna, če je tudi del trženja. S tem pa lahko pomembno vpliva na spremembo potrošniške kulture. Ima pa podjetje $\mathrm{C} v$ svoji strategiji zapisane inovacije, ki jih lahko razumemo $\mathrm{v}$ kontekstu znanja, kjer je inovacija zaznana kot proces, znanje pa kot osnova, dobrina, ki je potrebna za proces inoviranja (Leiponen in Helfat 20ro). Torej so zaposleni nosilci znanja in veščin, ki ga uporabljajo v procesu inoviranja.

Zanimivo je, da osebe visoko pripadnost podjetju opišejo (oseba $\mathrm{D}_{3}$ ): $\gg$ Tudi mi inženirji. Tudi za nas je pomembno, da znamo preklapljati možgane iz mehanike, kar je zelo zelo težko za nas. Če moramo zašraufati, moramo zašraufati, če je dizajnerju všeč ali ne, se pravi čim več ... Ta dizajnerska kultura je ne samo skupek teh stvari, interakcij, razmišljanja. Inženir je 24 ur. Jaz hodim po trgovinah tako (gleda gor, op. p.).«

D4: »To je poklicna deformacija, ko gledaš ...«

$\mathrm{D}_{3}$ : »Ni poklicna deformacija, ampak stvar poslanstva. Če ne opazuješ, kot otrok se učiš. Tudi pred službo in potem.«

Vidimo lahko, da zadovoljstvo in dobri odnosi niso le stvar poklica, osem ur službe, ampak ljudje to povzamejo in vidijo kot poslanstvo. Identiteto podjetja in vrednote celo ponotranjijo (Ashforth, Rogers in Corley 2010; Ibarra 1999; Pratt, Rockmann in Kaufmann 2006).

D2 pravi: »Zelo pomemben del. Pri zaposlenih se poudarja strast, da so pripravljeni timsko delati. Ne moreš biti tu znanstvenik. Moraš 
se vključevati, vsak doda nekaj. Sploh razvoj je pomemben in brainstorming. Se skupaj dobi neke rešitve.«

Vidimo, da gojijo visoko stopnjo pripadnosti, ki jo celo ponazarjajo $s$ strastjo.

Oseba Di omeni strast celo kot eno izmed vrednot v podjetju: »Poleg tega kvaliteta, dizajn, strast, usmerjenost $\mathrm{v}$ zeleno so tudi, mislim, da so korak zadaj.«

Strast je pomembna, ker je gorivo zaposlenega, da se soočajo $\mathrm{z}$ izzivi $\mathrm{v}$ poklicu. Je nekaj, kar da pomen. Za strast pri delu sta pomembna posameznikova identiteta in identiteta organizacije, okolja in kako se ti elementi prepletajo. Nenehne spremembe in inoviranje pa lahko to strast ohranjajo živo (Baird 2005). Podobno to ilustrirajo v podjetju D.

D4: »Jaz verjamem, če ni trenja, napetosti, ne da se trga, prave napetosti med trikotniki, potem stvar ne deluje. $\ll \mathrm{D}_{3}$ : «Enostavno ne razmišljaš, prideš v tirnice, ležernost.«

$\mathrm{D}_{2}$ : $\gg \mathrm{Ni}$ napredka.«

Kot vidimo iz analize intervjujev, se pojavlja še več nekakšnih podkategorij, ki so pomembne za odnose med ljudmi, za pripadnost podjetju, kulturo in s tem tudi pozicijo na trgu. Ti elementi, ki v pregledu literature niso bili vključeni, so znanje, strast, sodelovanje, participacija, samozavest. Te elemente smo predstavili v luči organizacijske kulture kot notranjega elementa organizacije in $v$ luči identitet kot zunanjega elementa, pa tudi osebnega.

\section{FFF - Form follows function}

Gre za Sullivanov koncept, ki je v oblikovalski in arhitekturni stroki splošno poznan in pomeni, da oblika sledi vsebini, se pravi Form follows function. Izkaže se, da se to načelo uporablja celo v naravi, saj so fiziologi odkrili, da to velja tudi za razvoj mišic v telesu (Russel, Motlagh in Ashley 2000). Iz pripovedi intervjuvancev smo ugotovili, da povezujejo formo in funkcijo. Kot lahko vidimo v nadaljevanju, se to odraža tudi v oblikovanju storitev. O tej povezavi govori Julier (2014), ko poveže oblikovanje nad linijo in oblikovanje pod linijo, kamor sodita tehnologija in funkcija. Različni avtorji pravijo, da tehnologija in družbene spremembe nastajajo sočasno (Ma in Agarwal 2007). Podobno lahko vidimo v arhitekturi, kako različno oblikovani prostori vplivajo na vedenje ljudi.

Intervjuvanka $\mathrm{A}_{2} \mathrm{v}$ podjetju A celo nacionalno kulturo povezuje tudi z visokimi ergonomskimi standardi: »Ne vem, kaj bi ... na splošno? Jaz bi rekla, da v Sloveniji je še precej borno razvita. Če primerjamo s skandinavskimi državami, smo zelo daleč nazaj. Ker tam je oblikovanje že del 
vsakdanjika. Oni so naredili strateški načrt za celotno Skandinavijo in vsi sledijo temu in zato so v toliko letih prišli do tega, kjer so sedaj, in tam vsakdo razume, kaj pomeni domače oblikovanje. Tuje izdelke težko spustijo noter, ker imajo dovolj svojih. Torej domačo proizvodnjo, domače oblikovalce. Zelo zaprt sistem in je težko priti noter. Tako smo se tudi mi sedem let trudili, da smo prišli na Dansko, kjer imamo največjo stranko, ampak je oblikoval danski oblikovalec. Tako da standardi so zelo visoki, ergonomija in tako dalje.«

Vidimo, da tudi ergonomija in skrb za zdravje kot vrednoti pogojujeta zahteve pri oblikovanju in sta del neke kulture. To je povezano s tem, da je oblikovanje v preteklosti služilo predvsem za izboljšavo pri delu, oblikovanju novih orodij. Danes pa je v veliki meri povezano z užitkom. Ko so izpolnjene funkcionalne zahteve, ponudi oblikovanje dodatno zadovoljstvo, ki je $\mathrm{v}$ današnji družbi, kjer so delo in zabava, strast prepleteni (Hancock, Pepe in Murphy 2005). Pogosto je ljudi strah napredka in razvoja, saj imajo občutek, da jih tehnologija odtujuje.

To podobno vidijo v podjetju B, kjer oseba BI pravi: »Ja, zelo velik pomen. Prva je jasno funkcija, drugo je stvar, ki nas zanima, je orientacija, ki je tudi povezana z oblikovanjem, to je druga stvar, ki nam je najpomembnejša pri izdelavi in postavitvi objekta. Potem pa je takoj dizajn, ki je od začetka povezan s prvima dvema. Bom pa rekla, da glede na to, da so ljudje bolj pragmatični, da so se kvadrature zmanjšale, je 'budžet' pomemben, sploh pri montažni gradnji, kjer kupec dobi ceno takoj napisano, pa dostikrat brez sape ostane. Če vidiš hišo, bo to naslednje leto toliko, pa naslednje leto toliko, tukaj pa dejansko dobiš celotno ceno takoj servirano. Je dostikrat tudi dizajn zelo podrejen tej praktičnosti. Po domače. Pri večini ne moreš afen guncati, ampak zaenkrat smo imeli srečo, so bile vse stranke zelo odprte za neke drugačne oblike. Največje povpraševanje je $v$ bistvu po tej hiši, ki je zelo netipična za nas. Bi človek rekel, da skoraj ne bi verjel. Pa za tole, ki smo jo tudi že naredili. Dejansko pridejo zaradi oblike. Se prav vidi. «

Vidimo, da na neki način lahko tudi proračun umestimo v kategorijo funkcije. Proračun vpliva na izbiro materialov, izvajalcev. Temu je potem tudi podrejena oblika. Zelo pomemben element $\mathrm{v}$ arhitekturnem oblikovanju je orientacija. Tudi ta vidik lahko vzamemo kot neko funkcionalno predpostavko, ki ji sledi oblika. Pojem funkcije je torej zelo široko zastavljen. Ko oseba B govori o povezavi kvadratur in proračuna, lahko vidimo, kako je ekonomska situacija spremenila kulturo ljudi, njihove vrednote, kar posredno vpliva na proizvajalce, ki morajo svoje izdelke prilagajati spremenjenim vrednotam in željam. 
Vpeljava jekla in betona $\mathrm{v}$ gradbeništvo je posledica tehnoloških, proizvodnih sprememb. To je pripeljalo do širokih razponov in gradnje $\mathrm{v}$ višino. Takrat so imeli arhitekti, ki so se združevali na konferenci CIAM, ideje, kako ne le oblikovati drugačna, sodobna mesta, temveč kako spremeniti družbo.

Vrednote $\mathrm{v}$ povezavi s funkcijo in oblikovanjem vidijo tudi v podjetju C. Tako oseba Ci pove: »Ja, pri vseh vrednotah, ja, če želiš biti produktiven, finančno uspešen, morajo biti izdelki teoretično dovolj preprosti, da so profitabilni, da jih proizvodnja hitro, učinkovito, torej z malo napakami tudi sestavi, proizvede. Bolj, še bolj pa iščemo preprostost v komunikaciji. Naša inovacija, katerokoli inovacijo naredimo, sploh v višjih cenovnih razredih, pa dejansko tudi otroških smučk, so v bistvu najcenejši produkt na trgu, se trudimo, da je tehnologija pokazana na preprost način navzven. Pri tej smučki z rebri nakazujemo zgradbo smučke in pravimo, da je smučka lahko upogljiva. In dejansko jo tudi otroci z zelo nizko težo prej in lažje upognejo kot konkurenčno ali našo predhodnico. In tukaj dizajn vedno podpira tehnologijo. Tehnologija je prva, potem jo dizajn podpira in pri nas je dizajn podpiran na preprost način. Da otroški uporabnik lahko prime, začuti, in v drugem koraku tudi na smučišču. Tudi razlaga je ... Inovatorji zakomplicirajo, mi se trudimo, da so zelo preproste, da jih lahko uporabnik razume. Veliko ljudi gre kupovat smučko in jih ne zanima prav zares, kaj vse je notri in kaj bodo imeli od tega. Vedno bolj delamo na tej preprostosti. Te tri točke so zmeraj.«

Tudi tukaj lahko rečemo, da je funkcionalnost tista, ki narekuje oblikovanje. To se odraža tako na vidnem kot na tipnem področju same smučke.

Oseba Ci pravi: »Odgovorim ne čisto direktno. $V$ eni od treh točk je dizajn. Ker dajemo močan poudarek na dizajn. Dizajn podpira tehnologijo. Če imamo zanimivo tehnološko inovacijo, se potrudimo, da je, da se jo vidi. Najprej $3 \mathrm{~d}$ dizajn, nato $2 \mathrm{~d}$ dizajn, da je ne prekrije, skrije, da je ta pač poudarjena.«

Vidimo lahko, kako deluje oblikovalski vidik, kjer se odločijo, ali bo način delovanja izpostavljen ali prikrit in drugotnega pomena.

$\mathrm{V}$ podjetju C so za povezovanje vseh funkcij in delov, ki so potrebni pri nastajanju novega produkta, povezali v centralno službo produktno oblikovanje.

To oseba Ci opiše: »Sploh produktno je tak povezovalni element. Razvoj gre v proizvodnjo, prodaja, marketing, produktno je tukaj res $\mathrm{v}$ sredini in je skozi buffer srce podjetja. Vse je eno, ki uravnava med eno in drugo stranjo, omejitve, možnosti, želje.« 
Tudi $\mathrm{C}_{3}$ pravi: »Dizajn se mi zdi pomemben. Ljudje kupujemo z očmi, sploh ženske. Pa dizajn ni sama lepota, ampak tudi funkcionalnost. Mi tega, da dizajn gledaš kot lepoto, mi tega vpliva nimamo. Zato so oblikovalke in to naredijo. Lahko pohvalimo ali skritiziramo. Če pa bi kaj glede dizajna, če je tehnična težava, se dogovorimo in potem probamo sam dizajn spremeniti. Naša stvar je funkcionalnost same smučke. To dodajamo in spreminjamo, da smo v koraku s časom. Če nisi v koraku s časom, te povozi.«

Lahko rečemo, da v podjetju C sledijo svoji strateški usmeritvi, najprej je tehnologija in šele nato temu sledi oblikovanje. Tehnologija je tista, ki jo tržijo, ki usmerja podjetja, dizajn pa jo podpira, pomaga k lažjim odločitvam kupcev.

Oziroma lahko to povežemo s pojmoma trenda in strategije, kot pravi oseba $\mathrm{C}_{3}$ : »Oblikovanje se ne razume, kaj boš oblikoval, če ni nekaj novega. Oblika je, moraš nekaj novega dodati. Nekaj lepega, načičkanega. Temu pravim make up. One morajo dati make up, tisto, kar je trend. Mi tehniki že uredimo tisto funkcionalnost, da je smučka vozna, kremo s tehnologijo naprej. Oni pa delajo make up. Včasih so bile take frizure, danes pa take, ker tega ne bo nihče kupil. Zato so nove vsako leto. Eno leto so take, drugo take. Eno leto srebrna, drugo leto $\mathrm{Ne}$, je fluorescentna. Morajo pogledati, pokombinirati in nam prilagoditi, da jih lahko naredimo. Ni, da si samo zmisli, da bo toplotni tisk. Ali bo sploh držal, koliko časa bo držal.«

Tako vidimo, da je tehnologija del strategije, dizajn pa je razumljen kot del trenda. Čeprav se vsi zavedajo, da mora biti oboje, dajejo prednost inovacijam.

Oseba Ci: »Saj vidite čez vse, cel sklop. I-ı je 9, še bolj kot tehnologija. No, ne, v bistvu je 7-10 ali 8/10.Oblikovanje vedno sledi tehnologiji. Nikoli ni v prvi vrsti.«

$\mathrm{V}$ podjetju $\mathrm{D}$, kjer načine dizajn managementa uporabljajo in se na tem področju izobražujejo, oseba Di prikaže primer, ki ni vezan na njihov prodajni izdelek: »N-oblikovanje je ful pomemben del, bom povedala na primeru. Ko smo delali katalog, je bilo super, smo prvič hkrati delali vsebino in oblikovanje. Ravno zaradi tega, ker smo to delali znotraj marketinga, smo prišli do rešitev, če bi delali zaporedno, ne bi dobili. Zdaj z internetom bo enako. Prej je bilo, da je nekdo nastavil vsebino, podatke, je končal in je oblikovalec potem to nadaljeval. Ko prvi konča in preden drugi začne delati, se zgodi, da ta prvi že pozabi malo, ni več toliko notri in se mora ves čas vračati, da se srečata. Drugače pa lahko ustvariš nove rešitve, ki jih posameznik ne bi mogel. To je prednost na primeru. 
Konkretno na primeru grafičnega oblikovanja. Internet vidim en vidik, ko to začneš deliti z oblikovalci, ti dodajo nove rešitve, na katere ne pomisliš. Če znaš to združiti in zapakirati, potem to funkcionira.«

Vidimo, da v podjetju Di procesa tečeta sočasno, simultano in opažajo, da takšen način dela pripelje do boljših rešitev. Zaznamo lahko način oblikovalskega mišljenja.

Oseba Dı še opisuje: »Je del ustvarjanja koncepta. Pa tudi recimo mi je prav super pri projektu kataloga, če je prej oblikovalec, je sama komunikacija. Nismo vstopali na področja. Sedaj lahko vstopim v oblikovanje, oblikovalec $\mathrm{k}$ meni in rata dobro. Sedaj smo imeli koncept, da smo nastavili koncept predstavitve nekega produkta na 70 odstotkov, v katalogu in potem smo dali ven, da dobimo čim več napak, predloge, kaj bi še lahko, vidimo, kaj ni razumljivo, da se tisto izboljša in zaključi. Kar pomeni, da se ljudje že dosti prej začnejo učiti o nekem produktu, kako bi se, če ne kak mesec prej.«

Iz navedenega lahko prepoznamo oblikovalsko mišljenje kot analiziranje, eksperimentiranje, ovrednotenje rezultatov (Razzouk in Shutte 20I2). Morda lahko rečemo, da je način form follows function del oblikovalskega mišljenja, ki je oblikovalcem samoumevno in priučeno $\mathrm{v}$ procesu izobraževanja (Johansson-Skoldberg, Woodilla in Cetinkaya 2013; Brown 2009). Kar je bistvo tega, je opredelitev problema, začetno stanje nezadovoljstva.

Tega se zaveda tudi oseba $\mathrm{D}_{\mathrm{I}}$ : »Ko enkrat dobiš problem in najdeš rešitev, je simpl od tam naprej.«

Tudi oseba $\mathrm{D}_{2}$ pravi, da je treba iti onkraj samega izdelka: »Imamo skupine svetil, linijske in takšne in drugačne že po funkcionalnosti in po prostoru. Ne da mi želimo v bistvu iz prostora izhajati, obrnjena logika. Iz prostora izhajati. Zato je pač tako pomembna ta predstavitev stranki postavljenega svetila v prostoru.«

$\mathrm{V}$ primeru podjetja $\mathrm{D}$ oblika sledi ne le tehničnim zahtevam, temveč $\mathrm{v}$ to vključuje celotno končno uporabo. Se pravi, je tu element vživetja $\mathrm{v}$ končnega uporabnika. $Z$ domišljijo se načrtovalci, oblikovalci skušajo vživeti in predvideti, kako bo uporabnik določen predmet uporabljal. To prinaša dodatno, kompleksno dimenzijo v oblikovanje (Verbeek 20ıо). O tem smo tudi govorili na primeru načrtovanja Slovenske ulice, kjer se je vnaprej predvidelo drugačno vedenje in uporabniška izkušnja udeležencev v prometu.

O tem govori tudi oseba $A_{I}$ : $\gg$ In s tem smo tudi predstavili vizijo, kaj si predstavljamo pod oblikovanjem. Jaz o pohištvu govorim, 40 let se razen črte na papirju v pohištvu ni veliko spremenilo. Vsaj is let pa je že 
neka tehnologija, ki se uporablja v avtomobilih, stanovanjih, ki pa je v pohištvo nismo vgrajevali. Sedaj to podjetja prepoznavajo. Deset let je že termin internet of things. V Sloveniji se to šele sedaj govori. Bolj menim da je na koncu pomembno, kaj ljudem omogočiš, rečeš, glej, s tem bo neki napredek pri vas. Je pa zelo tanka ta linija. Kaj je tisto, kar je brezveze, kar ti svinja čas, ali pa tisto, kar je dobro. Vsi stremimo, da bi naredili tisto, kar je dobro.«

Vidimo lahko, da vsi intervjuvanci razumejo način oblikovanja form follows function in temu $\mathrm{v}$ podjetjih dajejo različen poudarek. $\mathrm{V}$ podjetju B in C dajejo prednost tehnologiji, ki jo podpira oblikovanje. Podjetji $\mathrm{A}$ in $\mathrm{D}$ pa razumeta oblikovanje kot vživljanje $\mathrm{v}$ uporabnika in z uporabo nove tehnologije omogočajo drugačno uporabniško izkušnjo. Gre za oblikovanje izkušnje, o čemer govorita tudi Heskett (20I I) in Juliar (200I), ko opredeljujeta oblikovanje in področja, ki jih oblikovanje pokriva.

Moramo pa omeniti, da se je že v 8o. letih prejšnjega stoletja v trženju zgodil preobrat od trženja izdelkov $\mathrm{k}$ trženju veščin znanja in procesov. Procesi v trženju, ki to nakazujejo, so soustvarjanje vrednosti, procesi, potrošniška izkušnja, ko se odnosi kupcev začnejo s skupnim inoviranjem, podajanjem informacij (Payne idr. 2009). Vidimo lahko, da sta podjetji A in $\mathrm{D}$ precej aktivni na tem področju in to vnašata v svoje produkte in storitve.

Lahko rečemo, da je koncept form follows function vezan na klasično proizvodnjo predmetov, medtem ko v globalni postmoderni (družbi spektakla) prihaja do širjenje tega koncepta.

\section{Nagrade}

Skupna kategorija vsem intervjuvancem je kategorija nagrade. Pri tem sta nastali dve podkategoriji, ena je »ples na trgu «, ki govori o tem, kaj nagrada pomeni na trgu, se pravi v kontekstu znamčenja, druga pa $\gg$ pohvala $\ll$ v kontekstu notranjega zadovoljstva, dviga motivacije.

\section{Ples na trgu}

Nagrade se podeljujejo na različnih področjih in ena izmed teh, Red Dot Award, je nagrada za oblikovalsko odličnost. Lahko rečemo, da nagrada deluje kot benchmarking, orodje, ki ga menedžerji uporabljajo za ugotavljanje pozicije na trgu, za spodbudo za spremembo strategije, ugotavljanje konkurenčnih prednosti (Vorhies in Morgan 2005). Tako oseba A I iz podjetja A pravi: 
>Tako kot bi moralo, če bi bilo prav narejeno. Zmeraj se vprašamo, kaj lahko mi ponudimo kot rešitev, jaz sicer ne zagovarjam najbolj, da je treba ljudi spraševati, kaj potrebujejo. Menim, da je treba opazovati in jim ponuditi tisto, česar ne poznajo, predvsem združevati, kar mi pri pohištvu delamo. Združevati neko tehnologijo, materiale za to uporabniško izkušnjo, ampak z uvidom, kakšen je potem odnos do okolja. Zmeraj pravim, da damo človeka na človeka in okolje, preden se gremo finančni ples kaj, kje, kako, zakaj.«

Kot vidimo, so za osebo A I pomembna vprašanja, ki vključujejo elemente identitete, kdo sem, kaj sem, zakaj, kako (Monfort, Sebastián in López 2015).

O pomenu znamčenja in uporabniške izkušnje govori $A_{I}$ : »Ta uporabniška izkušnja ali pa service design, kako stranka pride do nas. Tukaj je skladišče, nekdo, ki pride prvič, ti so iz Dubaja, jih želimo sprejeti spredaj, da jim neko zgodbo kot celoto predstavimo. In podjetja se tega pri nas v Sloveniji sploh ne zavedajo. Država kot taka, da ne moreš dajati turizma in gospodarstva narazen. Jaz k temu težim. Prvo ljudem, ko pridejo, sploh ne kažem firme, produktov, ampak jih peljem pogledat, kakšna je Ljubljana, Slovenija, da vidijo kulinariko, ljudi. Če se ljudje med seboj ne poštekamo, če se okoli denarja ne bomo dogovorili, itak ne bomo naredili biznisa, samo če se bomo kot ljudje poštekali, imamo večjo priložnost. Mi smo tako posle dobili, ko, ne vem, deset let nič nismo delali, potem pa se je gospa, ki je bila že v pokoju in še angleško ni govorila, spomnila in poklicala in rekla, da ima podjetje, ki bi z nami delalo. Ker si je pač zapomnila, da se je tukaj dva dni dobro imela.«

Vidimo, da lahko gre znamčenje onkraj ozkega okvira podjetja, storitev.

Oseba Arpove: >In tudi Danci imajo v strategiji države napisano, da so oni prepoznavni po scandinavian designu. Ko so padli ven iz peterice na svetu, so velika sredstva vložili, da so spet prišli gor. In vsi vemo, da je to dober citat od Klinarja, da dober dizajn ustvarja srednji razred in da dobrega dizajna nasprotno ni brez srednjega razreda, ki si to lahko privošči. To je direkten vpliv na družbo in če politika tega ne razume ... Dejstvo je, da sredstva so. Porabljajo se za predstavitve, mi pa nimamo kaj predstavit. Vedno pravimo, pojdimo dva koraka nazaj, dajmo tretjino tega v izobraževanje, se pravi, neki dizajn management uvesti v podjetja, tako kot smo mi.«

Primer benchmarkinga je lepo opisan na primeru Danske, kjer vidimo, da gre benchmarking iz okvirja podjetja, na nacionalno raven. Država temu prilagaja strategijo, ki je obenem skladna z identiteto države. 
Še bolj nazorno oseba Aı opiše v kontekstu Red Dot Award: »S podjetniškega vidika pa je Red Dot nagrada neki benchmark, se pravi, da se o nekaterih stvareh sploh ne pogovarjaš, sploh s partnerji, kupci, kjer je ta logika oblikovalska, kultura že razvita. Se pravi, tam se ne pogovarjamo, tudi cena ni več prva, ki mora biti nizka. Mora biti price performance ta pravi. Tudi potem neki naročniki nate drugače gledajo v primerjavi z drugimi, ker vedo, da določen del sredstev namenjaš za razvoj, in mi jih ravno želimo prepričati, da smo tisti, ki jim lahko pomagamo. Se pravi z Red Dot pomagamo tudi njim. Se zelo radi vsi priklopijo na to zraven. Vsak to uporablja.«

Lahko vidimo, da je pomen nagrade velik, saj podjetju omogoča boljšo pozicijo na trgu, višjo ceno. Popolnoma drugačno izhodišče na trgu.

Podobno vidi nagrade oseba $\mathrm{C}_{4}$ iz podjetja $\mathrm{C}$ : »Tako kot v šoli dobra ocena. To je dobra referenca, to je uveljavitev na trgu, to je zaupanje. Ker sploh te mednarodne nagrade, to jih mi tudi tržimo tako, da s tem na trgu dobivamo zaupanje, višjo pozicijo, višjo ceno. To je potrditev za kakovost.«

Podobno je v podjetju $\mathrm{D}$, kjer oseba $\mathrm{D}_{2}$ pravi: $\gg$ Kot neko dobro promocijo, da bi neke prodajne številke $\mathrm{z}$ enim produktom ja, z ostalimi bolj promocija blagovne znamke in prepoznavnosti na trgu. Sigurno dobrodošla, zato prijavljamo in še vedno bomo.«

Pri tem je treba poudariti, da ima nagrada Red Dot kriterije, ki so jasni in niso osredotočeni zgolj na obliko.

Oseba Aı: »Pomembno je, kaj je zadaj, kaki so kriteriji. Tu ni kriterij, le oblika. Verjame, da smo z zgodbo, kjer verjamemo, da so smeti lahko material prihodnosti, v smislu industrijskega materiala uporabljaš, to zgodbo smo tudi napisali. Tudi te neke sistemske stvari, modularne.«

Tudi v podjetju B cenijo, da so kriteriji izbire za nagrado, in opisujejo, kako so občutili pomen takšne nagrade ob njeni podelitvi.

Oseba $\mathrm{B}_{\mathrm{I}}$ : »Ko je bilo narejeno, smo se z italijanskimi partnerji pogovarjali. Za prodajo $v$ tujini, sploh pri manjših stvareh, je prepoznavnost branda in nagrade pomembna, in so predlagali, naj ga prijavimo. Nisem vedela, da lahko manjši objekt prijaviš na Red Dot.

Oni so ob komunikaciji, med prijavo in ob nagradi, oni so tudi v bistvu, niso brand ampak organizacija, zelo rastoča. Konstantno iščejo neke nove stvari, niše, kamor bi se tudi oni širili kot Red Dot Award. Ko vidiš ves organizem, te ne čudi, da vključujejo vse to.

To je noro. Osebno, lani, ko smo tam sedeli, v teatru v Essnu, ko kličejo ljudi gor na oder. Tudi Gorenje je dobilo nagrado. Gorenje je velika tovarna, mašinerija. So bili trije oblikovalci in so bili kapljica. Lani je bil 
design team v Boschu, koliko je prisotnih ljudi ... noro ...v bistvu si kar ponosen nase, da si lahko vključen $\mathrm{v}$ družbo teh ljudi, ki so bili prisotni. 38 oblikovalcev samo za Bosch Evropa. Ena gospa cel dan samo barve določa. Noro ...«

Lahko vidimo, da lahko nagrada krepi prepoznavnost ne le navzven, temveč krepi tudi identiteto zaposlenih.

$\mathrm{V}$ podjetju B vidijo nagrado podobno, kot možnost trženja, ustvarjanja prepoznavnosti znamke. Torej v kontekstu znamčenja.

Oseba $\mathrm{B}_{\mathrm{I}}$ : »Trg je še vedno konservativen. Predvsem se mi zdi, da dosti dajo ljudje na znamko. Mi smo se tudi zato odločili, da gremo na Red Dot. Ti Italijani, ki sodelujejo z nami za italijanski trg, so nam predlagali. Se mi zdi, da pri nas ta branding tudi veliko pomeni, čeprav Red Dot ni tako poznan širše, je pa mogoče pri ljudeh, ki jih zanima sodelovanje z nami. Smo pa zanimivo, moj občutek je, da nismo konservativni na tak način, da nas ne pritegnejo novitete, ampak ko pride do stvari, kot je hiša ali pa avto, če gremo v praktično. Se pa zelo nanašamo na neke preverjene brande. Znotraj tega je preboj pri nas malo težji in se dogaja počasi. Tako je ta prepoznavnost znamke, sploh pri montažni gradnji, kjer so določene znamke že 30, 40 let, ki so pač znane, smo dobili občutek, da jim je bolj udobno z njimi sodelovati. Se zanašajo na reference. Zelo je vedno neka cena, prepoznavnost in kakovost. Te tri stvari se prepletajo. Če cena ni tako nižja, ja, nekaj je prepoznanih znamk in se mi zdi, da je bolj udobno sodelovati z nekom, ki ga poznajo. Mislim, da že nekaj nazaj je bila statistika, koliko novogradenj je montažnih, lesenih. Mislim, da 20 I šestnajst odstotkov, mislim, da je ta podatek zdaj bistveno višji kot še pet let nazaj.«

V podjetju B se zavedajo, da so majhni, da je vsakodnevnih nalog veliko in da bi potrebovali dodatne ljudi, da bi se bolje uveljavili na trgu. To oseba Bı opiše: »Definitivno je treba delati na trženju. Od Red Dot smo premalo iztržili. Nikjer ni bilo prav objavljeno. Ko dobiš nagrado, dajo predpripravljen press release. Samo vpišeš svoje ime. Smo ga prevedli in poslali vsem medijskim hišam. Mislim, da je samo Delo objavilo novičko. Sedaj pa vidim, da so povezano objavili novico. Lani tega sploh ni bilo. Tudi Gorenje je dobilo, pa mislim da Gigo design. Ampak ni bilo nikjer. Ne vem, zakaj. Morda bi se morali skupaj združiti in narediti konferenco. Smo imeli toliko dela in je ušlo. Pomanjkljivost malega podjetja. Prednost je, da si fleksibilen.«

$\mathrm{V}$ podjetju $\mathrm{C}$ imajo veliko nagrad, ki imajo različno težo. Tako pravi za nagrado Red Dot oseba $C_{\imath}$ : $\gg Z$ Zunanjo potrditev. Nekaterim damo večjo težo, nekaterim manj. Manjšo, Red Dot je ena taka, je neodvisna. Je 
dokaz, da smo delali v redu. To so zunanji presojevalci, nam je lahko lepo. Ja. Eno so oblikovalske nagrade. Ste se osredotočili na Red Dot.«

Lahko vidimo, da je nagrada nekakšna potrditev pravilnosti delovanja in usmerjanja podjetja.

Oseba $\mathrm{C}_{4}$ pa o nagradi pravi: $\gg \mathrm{Z}$ eno besedo kakovost. Kakovost dizajna, kakovost kvalitete dela, kakovost komunikacije, tako celostno bi rekla. Tudi če imaš dober dizajn in ne znaš skomunicirati v firmi, ne moreš dobrega proizvoda na trgu predstaviti. To je osnovni cilj podjetja. Da s kakovostjo dosega boljše rezultate in konkurira na trgu. Gre tudi za storitve in ne le izdelek, ampak tudi storitev.

Predstavitve, servisiranje. Moraš predstaviti trgu, vzdrževati, skrbeti, da so informacije na voljo, servis, skratka, skrbeti, da je stranka ne le takrat zadovoljna, ampak tudi ko zadevo uporablja.«

Oseba $\mathrm{C}_{4}$ se zaveda pomena znamčenja in predstavitve na trgu. $\gg \mathrm{Z}$ eno besedo kakovost. Kakovost dizajna, kakovost kvalitete dela, kakovost komunikacije, tako celostno bi rekla. Tudi če imaš dober dizajn in ne znaš skomunicirati v firmi, ne moreš dobrega proizvoda na trgu predstaviti. To je osnovni cilj podjetja. Da s kakovostjo dosega boljše rezultate in konkurira na trgu. Gre tudi za storitve in ne le izdelek, ampak tudi storitev.«

Kot vidimo, tudi oseba $\mathrm{C}_{4}$ razume oblikovanje v širšem kontekstu, tudi kot oblikovanje storitve. Kot smo v analizi že omenili, je v prihodnosti trend oblikovanja storitev, opredelitev oblikovanja kot širšega pojma.

$\mathrm{V}$ podjetju D pomeni nagrada Red Dot prav tako zunanjo potrditev in aktivnost s področja znamčenja.

Oseba D4 pravi: »Zunanja potrditev. Preden smo prijavljali, smo hoteli na neki način malo dvigniti prepoznavnost podjetja. Tako dobiš zunanjo potrditev, da si inovativen, da si dober, čeprav pogosto ta izdelek ni množično prodajan. Dobiš na prepoznavnosti.«

Zanimivo je, da oseba $\mathrm{D}_{4}$ ni izpostavila, da dobiš potrditev za oblikovanje, temveč za inovativnost, kakovost. Vsekakor pa nagrada predstavlja večjo prepoznavnost.

Zanimivo je, da se pozicionirajo kot izdelovalci svetlobe in ne svetil. $\mathrm{V}$ tem njihove segmentu so v ospredju tehnične inovacije, kvaliteta svetlobe.

$\gg$ Najbolj to, ko delamo svetlobo, kjer je treba, kolikor je treba, kadar je treba. Dosti s temi orodji, katalog je še vedno najpomembnejši, internet je drugi. Dosti je na izdelkih, tudi širina portfolija, da delaš pisarno, da lahko celotno pisarno, ne le dva delčka. Da uporabijo brand za rešitev neke celote. Mislim, da na vse touch pointe daš prava sporočila, ki govorijo isto zgodbo s pravih vidikov, « pravi oseba D4. 
Vseeno se zavedajo, da je za znamčenje pomembna zgodba, ki je enotna, morda bi lahko rekli tudi iskrena, saj mora biti verodostojna $z$ vseh vidikov. To zgodbo poudari tudi pri tem, ko se primerjajo z drugimi znamkami.

O pomenu zgodbe govori tudi oseba $\mathrm{D}_{5}$, ki pravi: $\gg$ Drugače, ko pogledaš, ko prebereš, zakaj je nagrado dobila, in jo drugače pogledaš, ne vem, bolj pogledaš. Pogledaš, če so naše, tudi če niso, kako zgledajo, in primerjaš z našimi.«

Vidimo, da je za ustvarjanje notranje povezanosti in sodelovanje potrebna zgodba, ki pojasnjuje vse procese zadaj. Swap, Leonard in Shields (200I) pravijo, da je učenje hitrejše, če je podprto z zgodbami. Zgodbe so tudi pomembne za učinkovito podajanje informacij. Z zgodbo se učinkovito prenašajo elementi kulturne vrednote, izkušnje (Denning S. 2004).

Zanimivo je, da v podjetju $\mathrm{D}$ oseba $\mathrm{D}_{4}$ pravi, da se je pomembno prilagajati trgu, čeprav to prinese veliko dodatnih aktivnosti v podjetje: $\gg \check{C}$ smo pri dizajnu, do zdaj smo vsi del, razsvetljavo se je dobavni trend ustavil. Od letos naprej delamo svetila v 14 kataloških barvah. Če to kupcu ponudimo, da kombinira ... v dveh barvah je to prednost, da je možnost izbire barve. Recimo tudi z oblikovalskega vidika je neki dodatek k dizajnu. To je cel komplet.«

D3: »To je ta dizajnerska kultura, kar smo prej govorili, da je treba določiti, neki korak še narediti, se še širiti.«

D4: »To potegne zadaj ogromno neke logistike, ampak suma sumarum je velika prednost na tržišču, če lahko skombinirate zlato in vinsko rdečo barvo, če vam je všeč. Zakaj ne. Zdaj je bila črna, bela, siva.«

Vendar nagrada ni vse. Za uspešno predstavitev na trgu, pravi oseba Di, so pomembni sejemska aktivnost, katalog, spletna stran. V podjetju vidijo kot najpomembnejše za benchmarking sejem Lighting, ki poteka vsaki dve leti. Tam se predstavijo vsi pomembni proizvajalci svetil.

Oseba Di pravi: »Imamo ta sejem, ki je bil letos. Je zelo pomemben. Je najpomembnejši dogodek v lightingu, vsaki dve leti. Višek je marec, planiramo vsaki dve leti. Takrat je malo več izdelkov. Sedaj pa je šlo za prenovo portfolia na led, ker je bilo treba vse zamenjati, hrkati smo poenotili kose. Če smo imeli prej 240 različnih šraufov, smo sedaj prišli na, ne vem, deset, ki so za vse luči enaki. Kako hladilnik in led uporabiti na pet različnih izdelkih. Tako si zmanjšaš stroške zaloge.«

Prav tako je za podjetje A pomembna sejemska aktivnost, vključevanje $\mathrm{v}$ različne podjetniške projekte, kjer se pozicionirajo na trgu.

Oseba A2: »Tako da ceno lahko določa ravno ta dodana vrednost, ki jo prinese oblikovanje. To se kaže tudi, da hodimo na vse večje tuje sejme, 
Nemčija, Milano, Orgatec, in v bistvu London. Letos pridejo na vrsto vsi ti sejmi, razen Milana, ki je že sedaj. Letos ni office, pa tudi Moskva. Kjer se kaže le izdelke z dodano vrednostjo in želi s tem dokazati tujim strankam, potencialnim, da se odločijo za nas, da smo drugačni, damo na kvaliteto in dodano vrednost.«

Podjetja lahko kreirajo ceno in svojo uspešnost na podlagi uspešnega znamčenja, identitete na trgu, kako je prepoznano (Harris in Chernatony $200 \mathrm{I}$ ).

Iz analize odgovorov lahko vidimo, da je oblikovanje pomemben dejavnik ustvarjanja dodane vrednosti izdelkov. Prav to prinesejo nagrade za oblikovanje. Podjetja jih bolj ali manj intenzivno tržijo. Zavedajo se, da je tu velika priložnost, ki lahko pozitivno vpliva na dodano vrednost znamke, na višjo ceno, boljšo pogajalsko pozicijo. Pomen nagrad bo ob poplavi različnih izdelkov morda v prihodnje še pomembnejši. Vendar se podjetja zavedajo, da se ne morejo zanašati samo na nagrade, in to kombinirajo z drugimi tržnimi strategijami.

\section{Dober sem}

Vidik nagrade je lahko zunanji, kot smo videli v prejšnji točki. Lahko pa je pomemben element krepitev pripadnosti zaposlenih podjetju, krepitve identitete in kulture ter posredovanja vrednot na vse ravni organizacije.

Oseba Aı pove: »Kako vidimo ... malemu xx skače do stropa!«

$\gg$ Nagrade na ven so tudi nagrade na noter. Potrditev, da nekaj delaš, da ti je nekdo dal neki check. Mi vedno gledamo, aha, smo na pravi smeri. Tudi družba se tako odziva, stroka ampak je skoz prepričevanje. Drug drugega moramo poslušati. To se mi zdi ključno.« pove oseba Ar.

Za krepitev pripadnosti podjetju so nagrade lahko dobro orodje, kar potrdi oseba $\mathrm{A}_{3}$ : »To je kar veliko priznanje. Sem ... Nas potem zanima še druga faza, prodaja. Nagrada je fajn. Ne vem, najlepše je, da imaš potem za tem serije po tisoč komadov. Potem daš pa kapo dol. Fantje so kar pripravljeni pomagati, delati, soustvarjati. Se vam zdi, da ste bolj pripadni. Mislim, da ja, če so soudeleženi, potem ja. Eni čutijo tudi, da so sami del nagrade, da so si jo tudi oni prislužili.«

Podobno je v podjetju C, kjer oseba $\mathrm{C}_{\mathrm{r}}$ pove: $\gg$ Fantje so enako ponosni na Red Dot ali na performance nagrade, na testih, tam dejansko ocenjujejo smuči vseh proizvajalce. Gre za vse največje. Ko tam dobimo nagrado, tudi to, kar smo mi mislili, da je dobro, potrdijo drugi. Ja, vse pomaga. Nagrada je nagrada. Lahko jo daš na steno in pogledaš, ko si slabe volje.« 
Tudi oseba $\mathrm{C}_{4}$ pove, da je nagrada potrditev, ponos, da si v koraku s časom. Lahko potrdimo ta vidik identitete, ker nagrada potrdi, da si dober (Balmer 200I).

Občutke opisuje: »Je fino, da delaš v podjetju, ki dobiva nagrade, ki ni v ozadju, kjer se ne dogaja. To mi je fino, veš, da obstajaš, delaš korak $s$ časom, mi je glede tega všeč. Vem, da če bodo nagrade, bomo imeli posel in službe. Če ni nagrad, pomeni, da smo na repu, in potem ni služb.«

Podobno vidi nagrado delavec v podjetju $\mathrm{D}$, oseba $\mathrm{D}_{5}$ : »Nekaj ponosa je, drugače ne vem ... Pač drugega nekega takega pomena, sedaj bomo skakali, ni. Pač delamo naprej in delamo in upam, da bo še kakšna.«

Oseba D6 pa celo vzpostavi odnos s predmetom, ki je dobil nagrado. Nanj drugače gleda in jo motivira pri delu: »Zanimivo, primeš luč, ta je tista, ki ima nagrado. Ni tako, da je tista z nagrado bolj pomembna. Je pa zanimivo.«

$\mathrm{Na}$ podlagi analiziranih intervjujev vidimo, da so zaposleni nagrade veseli, jih spodbudi k še boljšemu delu. Kot pa smo videli v poglavju o ljudeh, lahko rečemo, da so komunikacija, dobri odnosi pomembnejši dejavniki pri motivaciji in napredovanju na delovnem mestu.

Celota analize intervjujev je zajeta $v$ poglavju zaključki in ugotovitve. Čeprav je običajno, da avtor odgovori na raziskovalna vprašanja, ki si jih je zastavil v raziskavi, je v tem delu smiseln in možen odmik od tega običajnega načina. Ugotovitve podajamo holistično, tako kot se je pokazalo $\mathrm{v}$ raziskavi, da je razumevanje oblikovanja dizajn managementa, oblikovalskega mišljenja in oblikovalske kulture celovito, prepredeno omrežje procesov, struktur in funckij $v$ organizaciji in odnosih organizacije $s$ trgom. 


\section{Sklep}

Živimo v oblikovanem svetu, obkroženi smo s kopico predmetov, ki so tako ali drugače oblikovani, proizvedeni. Predmeti okoli nas so pomembni, saj s tem sporočamo kdo smo, kaj smo. Predmeti niso le statična kategorija, ki zgolj obstaja. Vedno bolj nam narekujejo način uporabe in stem spreminjajo našo zaznavo sveta. Panoge, ki se ukvarjajo z oblikovanjem (produktno oblikovanje, arhitektura, moda, grafično, spletno oblikovanje), zavzemajo vedno večji delež v nacionalnih BDP-jih.

\section{Zaključki in ugotovitve}

Ob pregledu literature smo ugotovili, da je velik del razlik v pojmovanju dizajn managementa in kulture oblikovanja imanenten oblikovanju ter da izhaja iz opredelitve oblikovanja. Avtorji s področja oblikovanja pojmujejo oblikovanje kot temeljno človeško dejavnost, del procesa kulturalizacije, oblikovanje vidijo kot nosilce vrednot in sredstvo komunikacije med ljudmi, posebno v sodobni družbi. Pri tem je treba izpostaviti procesni vidik opredelitve, kjer gre za nenehne postopke in izboljšave, nenehno iteracijo procesa in iskanje najboljših, najustreznejših rešitev za obravnavani problem.

Sočasno se pojavljajo okrnjene opredelitve oblikovanja (Brown 2009; Borja de Mozota 2006). Te vidijo oblikovanje kot metodo, orodje, s katerim menedžerji dosegajo zastavljene cilje organizacije. Če je oblikovanje temeljna človeška lastnost, način delovanja, potem to težko zreduciramo na samo metodo, saj je že del nas. Bistvena sestavina oblikovanja je prev- 
praševanje, narava metode pa je sledenje predpisanim korakom, da pridemo do želenega cilja.

Temu sledi tudi opredelitev oblikovalskega mišljenja in mišljenja oblikovanja. Johansson-Skoldbergova, Woodilla in Cetinkaya (2013) kritično podajo razliko med njima. Pri čemer mišljenje oblikovanja (designerly thinking) opredelijo v skladu z definicijo Rossa, ki pravi, da je to del človeške kognicije. Oblikovalsko mišljenje (design thinking) pa opredelijo kot poenostavljeno različico mišljenja oblikovanja (designerly thinking), ki se uporablja znotraj menedžerskega sveta.

Pojavi se vprašanje, ali je znotraj organizacije res mogoče vse procese in aktivnosti prikazati kot del oblikovanja. Pred leti je bilo vse del managementa, zdaj pa je vse del oblikovanja. Iz analize intervjujev lahko vidimo, da ljudje zaznavajo oblikovanje kot ločen del ustvarjanja produkta, storitve, ki ima svoje lastne značilnosti, ki se zdijo neposnemljive oziroma jih težko prenašamo iz stroke v stroko. Tako kot pravi eden od intervjuvancev, da je inženir in tako tudi razmišlja, pri delu pa skuša razumeti oblikovalce in se jim s svojim delom približati pri iskanju skupnih rešitev. Če se postavimo v radikalno pozicijo, se lahko vprašamo, ali je lahko inženir oblikovalec, čeprav oblikuje in ustvarja novo tehnologijo, pri tem uporablja podobne načine dela, ali je zdravnik, ki išče rešitev za bolnika in ponavlja različne postopke pri postavljanju diagnoze oblikovalec?

Lahko rečemo, da bodo potrebne še dodatne analize in študije, kaj daje oblikovanju posebno mesto v družbi, posebno sodobni družbi, kjer oblikovalec ni posameznik, ki raziskuje in ustvarja, temveč je del tima, pogosto kompleksnega in sestavljenega iz predstavnikov različnih strok.

Kar pa lahko potrdimo, je, da je oblikovanje del kulture, da so oblikovani izdelki del kulture, saj nosijo v sebi sporočila, vrednote in pomene ter kot taki predstavljajo družbeni kontekst, $\mathrm{v}$ katerem so nastali. $\mathrm{V}$ raziskavi smo ugotovili, da je v preučevanih podjetjih prisotna oblika organizacijske kulture, ki bi ji lahko rekli oblikovalska. Vsi zaposleni so prepoznali oblikovanje kot eno izmed vrednot podjetja. Prav tako pravijo, da je oblikovanje skupaj z inoviranjem ena izmed strategij podjetja. To pomeni, da se na trgu predstavljajo kot podjetje, katerega vrednota je oblikovanje. Zanimiva je tudi visoka vključenost zaposlenih $\mathrm{v}$ postopke izboljšav. $\mathrm{V}$ treh podjetjih lahko zaposleni v proizvodnji predlagajo rešitve, ki so bolj tehnične narave. Lahko rečemo, da je prisoten nenehen proces preverjanja oblikovanja izdelka, njegove izdelave, tehničnih rešitev. Tudi nadrejeni pravijo, da je odziv velik in da zaposleni veliko prispevajo. Ključ temu visokemu in uspešnemu sodelovanju je komunikacija, kar so potrdili vsi intervjuvanci. Kot smo videli v uvodnih opredelitvah kulture, je komuni- 
kacija pomemben del kulture, saj sproža proces kulturalizacije. Vidimo, da je struktura $v$ organizacijah natančno opredeljena in podaja okvir delovanja, razmejuje funkcije. Znotraj togega okvirja lahko zaznamo prožne procese komunikacije, kjer zaposleni sodelujejo med seboj in katerih področja se včasih delno prekrivajo, čeprav se to $\mathrm{v}$ preteklosti ni dogajalo.

Kar je pri tem zanimivo, je sprememba nekaterih procesov, da ne potekajo več zaporedno, temveč vzporedno. To seveda ne velja za proizvodnjo, kjer je za izdelavo izdelkov potrebno slediti natančno določenim procesom. Vidimo pa, da se proizvodni procesi z izboljšavami nenehno spreminjajo. Lahko rečemo, da je ena izmed sestavin oblikovanja nenehna sprememba, proces, preizpraševanje. Druga pomembna značilnost procesov, ki potekajo v organizacijah, je sočasnost. Manj sledijo ustaljenim praksam delovanja, ko si faze sledijo druga drugi, zavedajo se, da je treba delati sočasno, sodelovati in tako iskati čim boljše, kvalitetnejše rešitve. To pa je ena izmed lastnosti oblikovalskega dela, kjer nekatere faze iskanja rešitev potekajo sočasno.

Posledica dobre in učinkovite komunikacije v podjetjih je kakovost, pripadnost, lahko rečemo pozitivna identiteta $\mathrm{z}$ organizacijami.

To se kaže $\mathrm{v}$ procesu vodenja proizvodnje. Pripadnost in ozaveščenost delavcev je tako visoka, da ne potrebujejo kontrolorja kakovosti in so zaposleni sami pozorni na napake, ki jih skupaj z nadrejenimi sproti odpravljajo. Podjetja slovijo ne le kot oblikovalska, temveč tudi kot visokokakovostna. Na podlagi izjav intervjuvancev lahko rečemo, da so za dobro in ustvarjalno delo potrebni spoštovanje, sodelovanje in dobra komunikacija.

Zaposleni v podjetjih na vseh ravneh so prepoznali oblikovanje kot strateško pomembno usmeritev. Opazili smo, da njihovo zavzetost pri delu in okrepljeno pripadnost podjetju nagrade $s$ področja oblikovanja dodatno krepijo. Vendar je prisotna tudi komponenta notranjega zadovoljstva in ustvarjanja pozitivne poklicne identitete. Na višjih ravneh je v večini podjetij nagrada na osebni ravni manj pomembna. Vsi se je veselijo, pravijo, da jim da potrditev, da prav in dobro delajo. Je nekakšen kompas, v katero smer naj gredo tako na osebni ravni kot na ravni podjetja. Bolj kot nagradam zaposleni v podjetjih pripisujejo večji pomen strasti, zanosu in zavzetosti pri delu. To strast pa povzročajo nenehne spremembe, ki so posledica oblikovanja in inoviranja v organizacijah. Daje jim zagon in njihovo poklicno identiteto dodatno utrjujejo.

Intervjuvanci tudi povedo, da ne le hodijo v službo, temveč opravljajo poklic, pri čemer orišejo, da tudi zunaj delovnega časa opazujejo in analizirajo produkte konkurenčnih proizvajalcev. To potrjuje teorije identite- 
te, ki pravijo, da je za podjetje, znamčenje na trgu pomembna tudi identiteta zaposlenih, ki so tudi v prostem času predstavniki podjetja. Vidimo lahko, da so zaposleni v veliki meri seznanjeni z identitetami podjetij, ki jih ta uporabljajo za pozicioniranje na trgu, in tej je prilagojena tudi njihova lastna, poklicna identiteta.

Identiteta je element kulture in zaposleni $\mathrm{v}$ podjetjih priznavajo oblikovanje kot enega izmed ključnih dejavnikov $\mathrm{v}$ podjetju. $\mathrm{V}$ tem kontekstu lahko govorimo o oblikovalski kulturi v podjetju. Vendar menimo, da je etiketiranje morda celo slabo, saj se pri tem lahko spregledajo druge vrednote in sestavine organizacijske kulture. Vsa podjetja so imela med vrednotami zapisane oblikovanje, inoviranje, kakovost, znanje, nekatera ekološko usmerjenost, vendar v različnih razmerjih. Ravno ta različna razmerja, ki so posledica notranjih in zunanjih, tržnih dejavnikov, jih delajo edinstvena. Lahko rečemo, da se $\mathrm{v}$ redukciji na izpostavljanje enega vidika ta kompleksnost in specifičnost izgubi. Kar pa ta podjetja povezuje, ni le ena vrednota, temveč skupek vrednot.

Lastnost oblikovanja je, da teži k razlikovanju, ustvarjanju drugačnosti. Če pogledamo na ta podjetja z zelo oddaljenega vidika, lahko vidimo, da so različno oblikovana.

Ob koncu raziskave lahko rečemo, da bi bilo treba v prihodnosti še bolj raziskati pojem oblikovanja, saj je, kot priznavajo tudi drugi avtorji, premalo raziskan oziroma ga je treba bolje umestiti v sodobni čas, kjer se kompleksnost oblikovanega okolja nenehno povečuje.

Tako kot je slabo in nevarno reducirati oblikovanje, tako je tudi slaba poenostavitev načina dela oblikovalcev na nekakšne metode in postopke. Obstaja veliko modelov, ki pomagajo menedžerjem pri odločanju, in vprašanje je, kam sodijo ti modeli, ki so nastali pri preučevanju dela oblikovalcev.

Oblikovalsko mišljenje se $\mathrm{v}$ svetovalnih krogih predstavlja kot zadnji hit, vendar je vprašanje, kam potem umestiti inovativno, kreativno mišljenje, kaj jim je sorodno in različno. Sternberg 2006) pravi, da je kreativno mišljenje lastnost vsakega posameznika, vendar ga vsak ne izvaja. Podobno pravijo za oblikovalsko mišljenje. Kaj je torej tisto, kar dela oblikovalsko mišljenje drugačno. Ali sta ta dva pojma enaka? Oblikovalsko mišljenje je torej predvsem predstavljenjo kot neki način postopkov. Ki pa so po drugi strani enaki postopkom inoviranja.

Naša raziskava je pokazala, da so pojmi, ki jih povezujejo z oblikovalskimi, zelo sorodni drugim pojmom in premalo raziskani. Poenostavitev oblikovalskega dela in njegovo nekritično vpeljevanje na vsa možna področja pa se zdi del svetovalne mode. 


\section{Predlogi za nadaljnje raziskovanje}

Da pa bi vseeno bolje razumeli podjetja, ki so dobila Red Dot nagrado, bi bilo potrebno nadaljnje raziskovanje. Predvsem bi se morali osredotočiti na razlike med njimi, na to kaj jih razlikuje od drugih podjetij. Primerjati bi jih morali s tekmeci v branži, ki nagrade nimajo. Predvsem je zanimiv vidik zaposlenih. Zdi se, da so zaposleni v teh podjetjih cenjeni, kar je nasprotno trendu vsesplošnega 'zastonjskarskega', prekarnega dela, ki se kot posledica krize uveljavlja drugod.

Raziskati moramo:

- podjetja, ki niso prejemniki te prestižne nagrade, in njihovo kulturo;

- izvesti kvantitativno raziskavo, kjer bi preverili povezanost procesov oblikovanja, inoviranja in pripadnosti organizaciji, saj so se oblikovali ti trije ključni koncepti kot močno povezani in pomembni;

- raziskati strategije in oblikovanje strategij v podjetjih po panogah, v katerih delujejo.

\section{Predlogi za prakso}

Vodilna avtorica knjige se je kot arhitektka in ekonomistka srečala s prakso v teh podjetjih, na način, ki jo je presenetil. Podjetja so ji razkazala proizvodnjo, se pripravila na intervjuje, se odzvala izjemno pozitivno in $\mathrm{v}$ izčrpnih intervjujih omogočila celovit pogled $\mathrm{v}$ njihovo kulturo in procese.

Na podlagi teoretičnih izhodišč, pa težko zavzamemo stališče, da je oblikovalski način delovanja edini pravilen, kar v svoji kompleksnosti kažejo tudi ta podjetja.

Namen raziskave je bil eksplorativen, kar smo tudi dosegli. Podjetjem pa bo omogočila še dodaten vpogled, mogoče tudi neke vrste ogledalo, kjer bodo sami prepoznali morebitne spodbude za spremembe. 



\section{Povzetek}

Sodobna družba je kompleksna, intenzivna in predvsem družba podob in potrošništva. To kompleksno družbeno okolje sestavljamo posamezni$\mathrm{ki}$, podjetja in različne institucije. Opredelitev našega okolja je veliko in izhajajo iz različnih družboslovnih in ekonomskih disciplin, vendar je vsem skupno, da današnje okolje opredeljujejo pojmi, kot so hitre spremembe, informatizacija in globalizacija, kar Bauman (2004) pojasnjuje in utemeljuje, ko pravi, da naše življenje prežemajo globalni procesi.

Da bi podjetja ohranila svojo konkurenčnost in obstala na trgu, se morajo hitro prilagajati in iskati nove načine, kako in katere produkte in storitve proizvajati ter kako jih tržiti. Cameron idr. $(2006,9)$ pravijo, da je življenjska doba skoraj katere koli tehnologije na planetu kratka, večinoma manj kot šest mesecev. Isti avtorji poudarjajo, da je treba povprašati vodilne v Microsoftu, Amazonu in drugih podjetjih, ki hitro prilagajajo storitve in izdelke potrebam na hitro spreminjajočih se trgih, kaj in kako delajo, da ostajajo vodilni na svojih področjih. Tako kaže, da bodo tisti, ki so počasni in preveč konservativni v razvoju novih izdelkov, zaostali.

Zato moramo osvetliti okolje, v katerem delujemo kot posamezniki, tako proizvajalci kot potrošniki. To okolje ni zgolj »prazno okolje «, ki ga polnimo s podobami, resnicami in idejami, ampak je okolje kultura, ki je Kneževič (20I4, 2I) ne razume kot napredovanje civilizacije, temveč kot »oblikovano in doživeto idejo resnice znotraj družbe «. Idejo resnice sicer nenehno preverjamo, se o njej sprašujemo. Del tega spraševanja je lahko povezan z estetiko in estetizacijo, kjer na obliko gledamo, kot da ima lastno vrednost. 
$\mathrm{V}$ času hitrega tehnološkega napredka in padanja meja postaja pomembna in poglavitna konkurenčna prednost oblikovanje. Kot pravi Julier (2006), je oblikovanje ne le ustvarjanje vizualnih podob, izdelkov znotraj vizualnega in materialnega sveta, temveč ustvarjanje sistemov, ki se pojavljajo znotraj vizualnega in materialnega sveta. Malosi, Popovic in Hickling-Hudson (2007, I) pravijo, da kultura ustvarja različnosti, ta pa je razkrita v vsaki človeški aktivnosti, vključno z izdelki, ki jih oblikujejo ljudje. V tem kontekstu je kultura del vrednotnega sistema, in sicer njegov dinamični del, $v$ katerem se nenehno vrednotijo in prevrednotijo oblike in pomeni. Ta »oblikovalski pogled « postavlja kulturo v vrednotni sistem, s čimer se loči od menedžerskega vidika razumevanja kulture organizacije, ki postavi v središče razumevanja kulture vrednote. $\mathrm{Na}$ neki način se $\mathrm{v}$ oblikovanju oblikujejo oblike in pomeni ter $s$ tem tudi ideje resnice.

Tudi podjetja so družbeni sistemi s svojimi vrednotami, kulturo, sistemi delovanja. Prek različnih sistemov in procesov ter aktivnosti skušajo podjetja svoje vrednote prenesti na svoje zaposlene, ki naj bi ravnali v skladu z njimi. Po drugi strani skušajo podjetja svoje vrednote, ki so vgrajene v izdelkih in storitvah prek znamčenja in drugih posrednikov, posredovati potrošnikom, kupcem. Pri tem nosi pomembno vlogo oblikovanje, ki je močno prepleteno s podjetništvom. Pri oblikovanju gre namreč za ustvarjanje predmetov, podob in sistemov, ki so del podjetniškega sveta.

Za opredelitev raziskovalnega problema nas zanimajo trije ključni koncepti. Oblikovanje, znamčenje in organizacijska kultura.

\section{Oblikovanje}

$Z$ razvojem oblikovanja, managementa in podjetništva je prišlo do mnogih sprememb v poslovnem okolju. Po drugi strani se podjetja vedno bolj zavedajo pomena oblikovanja, in to ne le kot oblikovanja lepih izdelkov, temveč kot načina mišljenja in delovanja, ki temelji na prepletu sistemov vrednot podjetja, kupca in potrošnika.

Zavest o pomembnosti oblikovanja je od nekdaj prisotna. V zadnjih 30 letih se skupaj z oglaševanjem in znamčenjem še bolj razvija in stopa v ospredje. Tako so mnoge oblikovalske agencije razširile svoje področje delovanja še na svetovanje podjetjem s področja znamčenja in obrnjeno nekatere oglaševalske agencije storitve oblikovanja. Tako se je začelo razvijati področje design managementa, ki ponuja nekatere praktične nasvete in rešitve podjetjem. Avtorji Borja de Mozota (2003), Brown (2009), Jenkins (2009) in Best (2010) pravijo, da dizajn management podpira torej predvsem razvoj kulture oblikovanja znotraj podjetij, ta pa naj bi pod- 
jetjem prinesla konkurenčne prednosti. Ti avtorji izpostavljajo kot ključni dimenziji konkurenčne prednosti znamčenje in inoviranje. Tudi Julier (20I4), ki je opredelil kulturo oblikovanja, izpostavlja znamčenje kot povezovalni člen.

Vrsta avtorjev izpostavlja inoviranje kot ključni proces v podjetju. Lee in Benza (2015) potrjujeta, da je inoviranje glavni vir diferenciacije in konkurenčne prednosti $\mathrm{v}$ čedalje kompleksnejšem in hitro spreminjajočem se poslovnem okolju 21. stoletja. Russell-Bennettova in Baron (2015) trdita, da le nov, svež način razmišljanja poganja razvoj.

Tudi slovenska podjetja delujejo v globalnem okolju, ki se hitro spreminja, zato se morajo na spremembe odzivati hitro in prožno. Spreminjanje in hitro odzivnost lahko dosežejo $\mathrm{z}$ načinom delovanja, to je, da uporabljajo oblikovalski način razmišljanja. Eden od načinov povečevanja konkurenčnosti je torej tudi spodbujanje dizajnerskega razmišljanja in dizajnerske kulture v podjetjih.

Johansson-Skoldbergova, Woodilla in Cetinkaya (2013, I2I) opisujejo paradoks, ko pravijo: $\mathrm{V}$ menedžerskem okolju je dizajnersko razmišljanje opredeljeno kot najboljši način biti kreativen in inovativen. $\mathrm{V}$ oblikovalskem okolju pa dizajnersko razmišljanje delno ignorirajo in ga jemljejo kot nekaj samoumevnega.« Avtorji vzpostavljajo dva pojma, to sta način »biti《 in »razmišljanje«. Oblikovanje razmišljanje in identiteta (biti). Pri tem avtorji uporabljajo dva različna izraza, prvi je design thinking, kot ga uporabljajo $\mathrm{v}$ poslovnem svetu, drugi pa designerly thinking, kot je uporabljen $\mathrm{v}$ oblikovalskem okolju. Tako opredelijo oblikovalsko mišljenje (design thinking) kot poenostavljeno različico mišljenja oblikovanja (designerly thinkinga). Ross (2015) trdi, da je oblikovalsko (dizajnersko razmišljanje) nekaj, kar je že inherentno znotraj človeške kognicije; je ključni del tistega, kar nas dela ljudi. Rosenberg, Chauvet in Kleinman (2015) menijo, da je lahko design thinking vir konkurenčne prednosti, če je vgrajen v korporativno kulturo, kakor tudi $\mathrm{v}$ strategije, procese in prakse, sisteme in strukture. Kadar podjetja uporabljajo ali želijo uporabljati oblikovalsko mišljenje (design thinking) v svojem okolju, je, kot pravi Buchanan (1992), pomembno predvsem to, kako razmišljajo o reševanju kompleksnih problemov, kjer je možnih več rešitev.

Znotraj tega menedžerskega diskurza se design thinking še naprej deli v način upravljanja oblikovanja in inovacij kot upravljanje in reševanje problemov znotraj organizacije in kot sestavni del menedžerske kulture. 


\section{Znamčenje}

Anholt (2003) pravi, da je vrednost znamke multiplikator vrednosti, in znamka kot taka predstavlja prednost za lastnika. Namen znamke je komuniciranje s trgom. Znamka predstavlja vrednote podjetja in tako omogoča kupcu lažjo odločitev. Gre za to, da je znamka simbol za vrednote podjetja, ki jih to posreduje kupcu. Zato avtorji, med drugimi Anholt (2003), izpostavljajo troje: (a) da je ime znamke obljuba, (b) da so bila velika sredstva vložena v izdelek in (c) da ta izdelek deluje tako, kot ime obljublja. Schultz in de Chernatony (2002) sta postavila opredelitev, kjer je predstavljen širši vidik znamčenja: »Znamčenje omogoča managementu celosten okvir za usklajevanje različnih aktivnosti, s katerimi podjetje izraža, kdo je in za kaj se zavzema.« Palomaa (2013) pravi, da blagovna znamka z ustvarjanjem obljub vzpostavlja odnose s svojimi deležniki - da bi te obljube uresničila, pa potrebuje inovacije. Inoviranje lahko izpolnjuje obljube blagovne znamke; skozi inoviranje posreduje znamka resnično in otipljivo vrednost odjemalcem v obliki novih izdelkov, storitev ter izkušenj (Abbing 20ıо).

Za preplet vrednot, ki usmerjajo delovanje podjetja, pravi Urde (200I), da so za znamčenje potrebni trije sklopi vrednot: notranje vrednote, ki so povezane z organizacijo, vrednote, ki opredeljujejo znamko, in vrednote, kot jih doživlja kupec. Notranje vrednote so organizacijske vrednote, življenjska pravila, kot pravi Urde (200I). Osnovne vrednote, ki ustvarjajo znamko, so jedro vrednot. Tvorijo bistvo znamke. Vrednote, ki jih zaznava kupec, pa so tiste, ki znamki prinesejo dodano vrednost. Ta dodana vrednost za kupca je lahko emocionalna, simbolična ali uporabna. Ravno to dodano vrednost lahko $\mathrm{v}$ veliki meri dosežemo ravno $\mathrm{z}$ oblikovanjem.

\section{Kultura organizacij}

Eden od ciljev dela je opredelitev dizajnerskega mišljenja, kot je opredeljen v menedžerskem okolju. Organizacijam je v veliko pomoč pri njihovem delovanju, usmerjanju in ohranjanju konkurenčnosti organizacijska kultura. Desserti in Rizzo (20I4) menita, da je razmerje med dizajnom in svetom proizvodnje vedno nihalo med dvema pogledoma: med redukcionističnim vidikom dizajna kot ene izmed veščin v proizvodnem procesu, ki jo potrebujemo za povečanje privlačnosti izdelka, in kulturnim vidikom dizajna kot tistega enkratnega sistema kompetenc, znanja in veščin, ki (vključno s predmeti, praksami, vrednotami in prepričanji, ki pripadajo dizajnerski kulturi) lahko prepoznajo inovativne rešitve, ki zadovoljujejo eksplicitne ali latentne potrebe ob vključevanju različnih omejitev. Chatman in Eunyoung Cha (2003) navajata, da je kultura sistem skupnih 
vrednot (opredeljujejo, kaj je pomembno) in norm (opredeljujejo ustrezen pristop in vedenje). O pojmu organizacijska kultura kot pomembnem dejavniku oblikovalskega mišljenja velja pripomniti, da v oblikovalskih virih in literaturi zasledimo izraz korporativna kultura, v menedžerski literaturi pa je veliko zapisov o organizacijski kulturi in njenih različnih tipologijah. Organizacijska kultura je torej lahko razumljena kot sinonim korporativne kulture ali pa je korporativna kultura vrsta organizacijske kulture, o čemer smopodrobneje pisali v poglavju o kulturi. Tukaj uporabljamo izraza kot sinonima.

Rosenberg, Chauvet in Kleinman (2015) ugotavljajo, da je vpliv organizacijske kulture na dizajnersko razmišljanje kritičen. Kotter in Heskett (1992) pravita, da je najustreznejša tista organizacijska kultura, ki vsebuje vrednote in norme, ki podpirajo inovacije in spremembe. Donker, Poff in Zahir (2008) so v empirični raziskavi ugotovili pozitivno in visoko statistično povezanost med organizacijskimi vrednotami in poslovnimi rezultati podjetja. Da pa je organizacijska kultura dejansko lahko strateška prednost, pravi Barney (1986), mora biti kultura pomembna, voditi mora podjetje $\mathrm{k}$ ekonomski uspešnosti, biti mora posebna, imeti lastnosti in značilnosti, ki jih nima veliko podjetij. Kot lahko vidimo iz opredelitve organizacijske kulture, lahko ta vsebuje tudi način razmišljanja, delovanja. V tem primeru dizajnerski način razmišljanja. Julier (2013) trdi, da se je kultura oblikovanja kot široko uporabljan termin uveljavila v prejšnjem desetletju, analitično pa opisuje sodelovanje domen dizajna, proizvodnje in potrošnje, znotraj katere domujejo vprašanja vrednosti, kroženja in prakse.

Uspešnost na trgu je ena od osnovnih postavk, zakaj podjetje sploh obstaja. Kot lahko vidimo, podjetja delujejo v globalnem okolju, kjer je močno prisotna dizajnerska kultura. Že zaposleni so del tega okolja in tovrstne vrednote in vedenja delno prinesejo s seboj v delovno okolje. Po drugi strani vidimo, da so uspešna podjetja tista, ki se zavedajo svojega kulturnega okolja, ki sledijo spremembam in inovacijam, te pa dosegajo z oblikovalskim načinom mišljenja kot osnovnim načinom delovanja. Raziskave kažejo, da so na trgu uspešna tista podjetja, ki imajo močno in posebno kulturo, katere sestavni del so vrednote sprememb in inovacij. V delu smo raziskali razumevanje koncepta dizajnerska kultura, teoretično in empirično proučili pomen, ki ga podjetja, ki so osvojila prestižno dizajnersko nagrado Red Dot Design Award, pripisujejo kulturi oblikovanja. Prepletata se dva vidika, menedžerski in oblikovalski, ki naj bi se združila v konceptu oblikovalske kulture. 
,Red Dot Design Award' je mednarodna nagrada za oblikovanje izdelka in oblikovanje komunikacije, ki jo že od leta 1955 podeljuje Design Zentrum Nordrhein Wesfalen v Essnu v Nemčiji. Obstajajo kategorije za oblikovanje izdelka, oblikovalske agencije in oblikovalske koncepte. Zmagovalni projekti so predstavljeni v muzeju Red Dot Design v Essnu in na Tajvanu. Leta 2014 so prejeli več kot 15.500 prijav iz 70 držav sveta (Red Dot b. 1.).

\section{Metodološke omejitve}

Ta študija je eksploratorna (Sagadin, 2004), kar pomeni, da smo naredili prvi vpogled $\mathrm{v}$ preučevani problem, zato smo se prilagajali situaciji v podjetjih. Podjetja so različna po velikosti, strukturi, intenzivnosti oblikovanja, zato je treba to razumeti kot metodološko omejitev. Prav tako ne moremo naših ugotovitev posploševati. Imena vključenih podjetij in intervjuvancev ohranjamo anonimna, saj so le tako bili pripravljeni sodelovati.

\section{Vsebinske omejitve}

Vsebinske omejitve so povezane z dejstvom, da je področje dizajn managementa empirično slabo raziskano. Obstaja pa veliko svetovalnih podjetij, katerih predmet delovanja je dizajn management. Vsebinsko omejitev smo implicitno zapisali in jo je mogoče razbrati iz namena raziskave. Omejili smo se le na tri vidike: organizacijsko kulturo, oblikovanje in dizajn management, mogoče pa bi bilo zajeti tudi druge vidike, kot so filozofski, sociološki, marketinški, potrošniški ipd.

Posebna omejitev in hkrati izziv je prevod angleških izrazov, ki so uveljavljeni $\mathrm{v}$ slovenskem prostoru. Terminologija $s$ tega področja ni razvita, kar kaže na slabo poznavanje tega področja in s tem razvoja slovenske terminologije. V knjigi ohranjamo angleške izraze in v oklepajih slovenske prevode, kot smo jih opredelili sami. Vsekakor so podani zgolj kot predlog, ki ga lahko stroka sprejme, spremeni ali dopolni. Prav tako je $v$ slovenskem in mednarodnem prostoru poznavanje dizajn managementa in področij, ki to obravnavajo, novo, zato ni relevantne literature, ki bi osvetlila nekatere osnovne pojme. Zato je bila posebna skrb namenjena pravilni opredelitvi osnovnih pojmov. Prav tako velja zapisati, da v knjigi večkrat dobesedno navajamo opredelitve, definicije ključnih avtorjev, posebno na področju oblikovanja, ki vstopa in se prepleta s področjem managementa. 
Ob pregledu literature smo ugotovili, da je velik del razlik v pojmovanju dizajn managementa in kulture oblikovanja imanenten oblikovanju ter da izhaja iz opredelitve oblikovanja. Avtorji s področja oblikovanja pojmujejo oblikovanje kot temeljno človeško dejavnost, del procesa kulturalizacije, oblikovanje vidijo kot nosilce vrednot in sredstvo komunikacije med ljudmi, posebno v sodobni družbi. Pri tem je treba izpostaviti procesni vidik opredelitve, kjer gre za nenehne postopke in izboljšave, nenehno iteracijo procesa in iskanje najboljših, najustreznejših rešitev za obravnavani problem. 



\section{Summary}

Modern society is complex, intensive and above all a society of images and consumerism. This complex social environment is made up of individuals, companies and various institutions. The definition of our environment is large and derives from various social and economic disciplines, but it is common for everyone to define terms today, such as rapid changes, informatization and globalization, which Bauman (2004) explains and argues when he says that our lives are permeated with global processes.

In order to maintain their competitiveness and remain on the market, companies need to adapt quickly and look for new ways in which to produce products and services and how to market them. Cameron et al. $(2006,9)$ say that the lifetime of almost any technology on the planet is short, mostly less than six months. The same authors stress that it is necessary to ask leaders of Microsoft, Amazon and other companies that quickly adapt services and products to the needs of fast-changing markets, how they manage to remain leaders in their fields. It thus shows that those who are slow and too conservative in development of new products will be left behind.

Therefore, we need to highlight the environment in which we act as individuals, both producers and consumers. This environment is not just an "empty environment" that we fill with images, truths and ideas, it is a culture that Kneževič (2OI 4, 2I) does not understand as the advancement of civilization, but as a "shaped and experienced idea of the truth within society". Idea of the truth that is being constantly checked and ques- 
tioned. Part of this questioning may be related to aesthetics and aesthetization, where we look at the form as having its own value.

At the time of rapid technological advancement and the decline of borders, the formation of an important and key competitive advantage is becoming crucial. As Julier (2006) says, designing not only the creation of visual images, products within the visual and material world, but the creation of systems that emerge within the visual and material world. Malosi, Popovic and Hickling-Hudson $(2007, \mathrm{I})$ say that culture creates diversity, which is revealed in every human activity, including the products produced by people. In this context, culture is a part of the value system, namely its dynamic part, in which they constantly evaluate and revalue forms and meanings. This "design view" puts culture into a value system, thus separating from a managerial viewpoint of understanding the culture of an organization that places itself at the heart of understanding the culture of value. In some ways, shapes and meanings, and thus the ideas of truth, are shaped in design.

Companies are also social systems with their values, culture, operating systems. Through various systems, processes and activities, companies try to transfer their values to their employees, who are expected to act accordingly. On the other hand, companies try to pass on their values, which are embedded in products and services through branding and other intermediaries, to consumers, customers. An important role is played by design, which is intricately intertwined with entrepreneurship. When designing, it is about creating objects, images and systems that are part of the entrepreneurial world.

Three key concepts are interested in defining the research problem. Design, branding and organizational culture.

\section{Designing}

With the development of design, management and entrepreneurship, there have been many changes in the business environment. On the other hand, companies are increasingly aware of the importance of design, and not just in the view of designing beautiful products, but as a way of thinking and acting, based on the interweaving of the value systems of the company, the customer and the consumer.

The awareness of the importance of design has always been present. Over the last 30 years, along with advertising and branding, it is further developing and coming to the fore. Thus, many design agencies have expanded their scope to provide advice to brand companies and viceversa, some of the design agencies offer advertising services. Thus, the field of 
design management started to develop, which offers some practical advice and solutions to companies. Authors Borja de Mozota (2003), Brown (2009), Jenkins (2009) and Best (2010) say that design management supports, above all, the development of a culture of corporate design, which should bring competitive advantages to companies. These authors point out that the key dimension of competitive advantage is branding and innovation. Julier (2014), who defined the culture of design, highlights the mark as a connecting link.

Many authors highlight innovation as a key process in the company. Lee and Benz (2015) confirm that innovation is the main source of differentiation and competitive advantage in an increasingly complex and rapidly changing business environment of the 2 Ist century. Russell-Bennett and Baron (2015) argue that only new, fresh thinking drives the development.

Slovenian companies also operate in a global environment that is changing rapidly, so they need to respond quickly and flexibly to changes. Changing and fast responsiveness can be achieved through the operating mode, that is, using the designing mindset. One way of increasing competitiveness is therefore the promotion of designer thinking and design culture in companies.

Johansson-Skoldberg, Woodilla and Cetinkaya (2013, I2I) describe the paradox when they say: In a managerial environment, design thinking is defined as the best way to be creative and innovative. In the design environment, design thinking is partially ignored and taken as something self-evident. "Authors establish two concepts, namely "being"and" thinking ". Forming thinking and identity (being). In this, authors use two different expressions, the first being design thinking, as used in the business world, while others designerly thinking, as used in the design environment. Thus, design thinking is designed as a simplified version of designer thinking. Ross (2015) argues that design thinking is something that is already inherent within human cognition; it is a key part of what people do. Rosenberg, Chauvet and Kleinman (2015) believe that design thinking can be a source of competitive advantage if it is embedded in corporate culture as well as in strategies, processes and practices, systems and structures. When companies use or want to use design thinking in their environment, Buchanan (1992) says that it is important to think about how to solve complex problems where multiple solutions are possible.

Within this managerial discourse, design thinking continues to be divided into a way of managing design and innovation as managing and 
solving problems within the organization and as an integral part of the managerial culture.

\section{Branding}

Anholt (2003) says that the value of a brand is a multiplier of value, and the brand as such is an advantage for the owner. The purpose of the brand is to communicate with the market. A brand represents the values of the company and thus enables the customer to make a decision easier. It is about the fact that the brand is a symbol for the values of the company, which it provides to the buyer. Therefore, the authors, among others Anholt (2003), highlight three things: (a) that the brand name is a promise, (b) that large funds have been invested in the product; and (c) that this product acts as the name promises. Schultz and de Chernatony (2002) have set out a definition where a broader aspect of branding is presented: "Branding allows management a comprehensive framework for coordinating various activities by which the company expresses who it is and what it takes." Palomaa (2013) says that by creating promises, the brand establishes relations with its stakeholders - in order to fulfill these promises, it needs innovation. Innovation can fulfill brand's promises; Through innovation, the brand makes real and tangible value to customers in the form of new products, services and experiences (Abbing 2010).

According to Urde (200I), for the interweaving of values that direct the operation of the company, three sets of values are needed for branding: internal values that are related to the organization, the values that define the brand, and the values that the buyer experiences. Internal values are organizational values, life rules, as Urde (200I) says. The core values that create the brand are the core of values. They form the essence of the brand. The values perceived by the buyer are those that bring added value to the brands. This added value for the customer can be emotional, symbolic or useful. This added value can be achieved to a large extent by precisely designing.

\section{Culture of organizations}

One of the book's objectives is to define the designer's thinking, as defined in the managerial environment. Organizations are very helpful in their functioning, direction and preservation of organizational culture. Desserts and Rizzo (2014) think that the relationship between design and the world of production has always fluctuated between two aspects: between the reductionist aspect of design as one of the skills in the pro- 
duction process that is needed to increase the attractiveness of the product and the cultural aspects of design as the unique system of competencies, knowledge and skills that (including subjects, practices, values and beliefs that belong to the designer culture) can identify innovative solutions that meet explicit or latent needs while integrating different constraints. Chatman and Eunyoung Cha (2003) state that culture is a system of common values (defining what is important) and norms (defining an appropriate approach and behavior). Whena talking about organizational culture as an important factor in design thinking it should be noted that in the design literature we see the term corporate culture, and in management literature there are many records of organizational culture and its various typologies. Organizational culture can therefore be understood as synonymous with corporate culture, or corporate culture is a kind of organizational culture, which we desribed in more detail in the chapter on culture. Here we use the terms as synonyms.

Rosenberg, Chauvet and Kleinman (2015) note that the influence of organizational culture on design thinking is critical. Kotter and Heskett (1992) state that the most appropriate is the organizational culture that contains values and norms that support innovation and change. Donker, Poff and Zahir (2008) found a positive and high statistical correlation between organizational values and business results in their empirical study. In order for organizational culture to be a strategic advantage, Barney (1986) says, culture must be important, it must lead to economic success, it has to be specific, have characteristics that other businesses do not have. As can be seen from the definition of an organizational culture, it can also contain a way of thinking, acting. In this case, the designer way of thinking. Julier (2013) argues that the culture of design as a widely used term has been established over the past decade, and analytically describes the cooperation of domains of design, production and consumption, within which values of value, circulation and practice are posed.

Performance in the market is one of the basic reasons why the company even exists. As we can see, companies operate in a global environment where design culture is strongly present. Already the employees are part of this environment, and these values and behaviors are partially brought into the working environment. On the other hand, we see that successful companies are those who are aware of their cultural environment following changes and innovations, and they achieve these with the designing mindset as the basic mode of operation. Research shows that those companies that have a strong and special culture, integral to the values of change and innovation, are successful on the market. In the work we ex- 
plored the understanding of the concept of design culture, theoretically and empirically examined the importance that companies, who won the prestigious design award Red Dot Design Award, attribute to the culture of design. There are two aspects, managerial and designerly, which are to be combined in the concept of design culture.

'Red Dot Design Award' is an international award for product design and communication design that has been awarded by Design Zentrum Nordrhein Wesfalen since 1955 in Essen, Germany. There are categories for product design, design agencies and design concepts. The winning projects are presented at the Red Dot Design Museum in Essen and Taiwan. In 2014, they received over 15,500 applications from 70 countries of the world (Red Dot, n.d.).

\section{Methodological limitations}

This study is exploratory (Sagadin, 2004), which means that we made the first insight into the problem under study, so we adjusted to the situation in companies. Companies are different in size, structure, intensity of design, so this should be understood as a methodological limitation. Nor can we generalize our conclusions. We keep the names of the companies and interviewees involved anonymous, as they were only willing to participate this way.

\section{Content constraints}

Content constraints are related to the fact that the field of design management is empirically poorly studied. There are, however, many consulting companies whose subject matter is design management. The content restriction is implicitly written and can be deduced from the purpose of the research. We have limited ourselves to three aspects: organizational culture, design and design management, while other aspects, such as philosophical, sociological, marketing, consumer, etc., could also be covered.

A special restriction and, at the same time, a challenge is the translation of English terms that are established in the Slovene territory. Terminology in this field is not developed, which indicates a poor knowledge of this field and, consequently, the development of Slovenian terminology. In the book, we preserve the English terms and in the brackets Slovenian translations, as we have defined ourselves. In any case, they are given only as a proposal that the profession can accept, modify or supplement. Similarly, in the Slovene and international context, the knowledge of the design management and the areas that deal with it is new, therefore, there 
is no relevant literature that would illuminate some of the basic concepts. Therefore, special attention was given to the correct definition of the basic concepts. It should also be noted that in the book, we repeatedly refer to definitions, definitions of key authors, especially in the field of design, which enters and intertwines with the field of management.

When reviewing the literature, we found that a large part of the differences in the concept of design management and design culture is immanent to design, and that it follows from the definition of design. Designers perceive design as a fundamental human activity, part of the process of culturalization, they see design as the bearer of values and a mean of communication between people, especially in modern society. In this context, the process aspect of the definition should be highlighted, where it is a matter of continuous processes and improvements, a continuous process iteration, and the search for the best, most appropriate solutions to the problem under consideration. 



\section{Literatura}

Aaker, David. 2007. Innovation: Brand it or lose it. California Management Review 50 (I): 8-24.

Abbing, Erik Roscam. 2010. Brand driven innovation: Strategies for development and design. Worthing: Ava Publishing.

Adorno, Theodor in Max Horkheimer. 1979. Dialectic of Enlightment. London: Verso.

Albert, Stuart in David A. Whetten. 1985. Organizational identity. Research in organizational behavior 7 (0): 263-295.

Alvesson, Mats in Stefan Sveningsson.2015. Changing organizational culture: Cultural change work in progress. Abingdon: Routledge.

Anholt, Simon. 2003. Brand New Justice: The upside of global branding. Oxford: Butterworth-Heinemann.

Ashforth, Blake E., Kristie M. Rogers in Kevin G. Corley.20 I I. Identity in organizations: Exploring cross-level dynamics. Organization science 22 (5): I I 44-II56.

Baccarani, Claudio in Gaetano M. Golinelli. 2015. The non-existent firm: relations between corporate image and strategy. Sinergie Italian Journal of Management 3 (97): 313-326.

Baird, Lynn. 2005. Change and connections: Passion and organizational change. Electronic Journal of Academic and Special Librarianship 6 (I/2): I-4.

Balmer, John M. T. 200 . Corporate identity, corporate branding and corporate marketing, Seeing through the fog. European journal of Marketing. $35(3 / 4)$. 
Balmer, John MT in Edmund R. Gray. 2003. Corporate brands: what are they? What of them?. European Journal of Marketing 37 (7/8): 972-997.

Barney, Jay B. 1986. Organizational Culture: Can it be a source of sustained competitive advantage? Academy of management review II (3): 656-665.

Baudrillard, Jean. 1994. Simulacra and simulation. Ann Arbor: University of Michigan press.

Bauman, Zygmunt. 2004. Work, consumerism and the new poor. London: McGraw-Hill Education.

Benders, Jos, and Kees Van Veen. 200I. What's in a fashion? Interpretative viability and management fashions. Organization 8 (I): 33-53.

Benjamin, Walter. 2008. The work of art in the age of its technological reproducibility, and other writings on media. Boston: Harvard University Press.

Best, Kathryn. 2010. The Fundamentals of Design Management. AVA Publishing sa.Lausanne.

Biloslavo, Roberto, Faganel, Armand, Kodrič, Borut in Anita Trnavčevič. 2012. Marketinška kultura $v$ storitvenih dejavnostih: izzivi za trajnostni razvoj. Koper: Fakulteta za management.

Binkley, Sam. 2000. Kitsch as a Repetitive System: A Problem for the Theory of Taste Hierarchy. Journal of Material Culture 5 (2): I3 I-I 52.

Birks, Melanie in Jane Mills. 2or I. Grounded theory: A practical guide. London: Sage publications.

Bjögvinsson, Erling, Pelle Ehn in Per-Anders Hillgren. 201 2. Design Things and Design Thinking: Contemporary Participatory design Challenges. Design Issues 28 (3): IOI-I 6.

Boland, J. Richard Jr., Collopy F., Lyytinen K. Yoo, Y. 2008. Managing as Designing: Lessons for Organization Leaders from Design Practice of Frank O. Gehry. Design Issues. 24 (I): $10-25$.

Borja de Mozota, Brigitte. 2003. Design Management. Using design to build brand value and corporate innovation. New York: Allworth Press.

Borja de Mozota, Brigitte. 2006. The four powers of design: A value model in design management. Design Management Review I7 (2): 44-53.

Bourdieu, Pierre in Richard Nice. 1980. The aristocracy of culture. Media, culture and Science 2(0): 225-254.

Bowman, Cliff in Véronique Ambrosini. 2007. Firm value creation and levels of strategy. Management Decision 45 (3): 360-37 I.

Braha, Dan in Yoram Reich. 2003. Topological structures for modeling engineering design processes. Research in Engineering Design I 4 (4): I85I99. 
Branzi, Andrea. 1986. We Are the Primitives. Design Issues 3 (I): 23-27.

Brewer, John in Roy Porter. 2013. Consumption and the World of Goods. London: Routledge

Brown, Tim. 2009. Change by Design: How Design Thinking Transforms Organizations and Inspires Innovation. New York: HarperBusiness.

Bryman, Alan. 2004. Interviewing in qualitative research. Social research methods 2 (0): 31 8-344.

Buchanan, Richard. 1992. Wicked problems in design thinking. Design Issues $8(2):$ 5-2I.

Buchanan, Richard. 1998. Branzi's Dilemma: Design in Contemporary culture. Dessign Issues. I 4 (I): 3-20.

Buchanan, Richard. 2008. Introduction: Design and Organizational Change. Dessign Issues. 24 (I): 2-9.

Cameron Kim. S. in Robert E. Quinn. 2006. Diagnosing and Changing Organizational Culture. San Francisco: Jossey-Bass.

Cameron Kim. S., Quinn Robert. E., Degraff Jeff in Anjan V. Thakor. 2006. Compeating Values Leadership. Creating Value in Organization. Cheltenham: Edward Elgar Publishing Limited.

Carr, Raymond in Juan Pablo, Fusi. 1981. Spain: Dictatorship to Democracy. London: Allen and Unwin.

Chatman, Jennifer A. in Sandra Eunyoung Cha. 2003. Leading by Leveraging Culture. California Management Review 45 (4) 20-34.

Chiva, Ricardo in Joaquín Alegre. 2009. Investment in design and firm performance: the mediating role of design management Journal of Product Innovation Management 26 (4): 424-440.

Corley, K. G. 2004. Defined by our strategy or our culture? Hierarchical differences in perceptions of organizational identity and change. Human Relations 57 (9): II 45-II77.

Criveanu Maria, Magdalena. 2015. The Impact Of Corporate Culture On The Effectiveness Of Companies. Annals-Economy Series 5: 74-78.

Debord, Guy. 2008. Scociety Of Spectacle. New York: Zone books.

Denison, Daniel R. 1996. What is the difference between organizational culture and organizational climate? A native's point of view on a decade of paradigm wars. Academy of management review 2I (3): 619-654.

Denning, Peter J. 2004. The social life of innovation. Communications of the $A C M 47$ (4): I5-19.

Denning, Stephen. 2004. Telling tales. Harvard Business Review 82 (5): I 22I29. 
Denzin, Norman K. in Yvonna S. Lincoln. 2000. Handbook of qualitative research. Thousand Oaks: Sage Publications.

Desserti, Alessandro in Francesca Rizzo. 2014. Design and the Cutures of Enterprises. Design Issues 30 (I): 36-56.

Deshpande, Rohit, and Frederick E. Webster Jr. 1989. Organizational culture and marketing: defining the research agenda. The Journal of Marketing 55 (I): 3-15.

Detert, James R., Roger G. Schroeder, and John J. Mauriel. 2000. A framework for linking culture and improvement initiatives in organizations. Academy of management Review 25 (4): 850-863.

de Certeau, Michel. 1984. The Practice of Everyday Life. Berkeley: University of California Press.

de Oliveira Janaina Mendes,Laranja Manuel, Lahorgue Maria Alice in Henrique Figueiredo Born. 2016. Cross Innovation Approach and the creative idustries: A case study in the city of Lisbon, Portugal. International Journal of Innovation 4 (I): I-I 2.

Dickson, Peter, Wendy Schneider, Peter Lawrence in Renee Hytry. I995. Managing design in small high growth companies. The Journal of Product Innovation Management I 2 (5): 406-415.

Donker Han, Deborah Poff in Saif Zahir. 2008. Corporate Values, Codes of Ethics and Firm Performance: A Look at the Canadian Context. Journal of Business Ethics 82 (3): 527-537.

du Gay, Paul. 1997. Organizing Identity: Making Up People at Work. London: Sage.

Easterby-Smith, M., R. Thorpe in A. Lowe. 2007. Raziskovanje v managementu. Koper: Fakulteta za management.

Egan, Toby Marshall, Baiyin Yang in Kenneth R. Bartlett. 2004. The effects of organizational learning culture and job satisfaction on motivation to transfer learning and turnover intention. Human resource development quarterly is (3): 279-30I.

Findeli, Alain. 200 I. Rethinking design education for the 2 Ist century: Theoretical, methodological, and ethical discussion. Design issues I7 (I): 5-17.

Fiske, John. 1989. Understanding Popular Culture. London: Routledge.

Frascara, Jorge. 200I. Introduction: Rethinking Design. Design Issues I7 (I): $\mathrm{I}-4$.

Frere-Jones, Tobias. 20ı6. Ko misliš, da je oblikovanje končano, ti je samo zmanjkalo sposobnosti, da bi opazil pomanjkljivosti. Outsider. Http:// 
outsider.si/ko-mislis-da-je-oblikovanje-koncano-ti-je-samo-zmanjkalo-sposobnosti-da-bi-opazil-pomanjkljivosti/ (15. 3. 2016).

Gaisina, Lyutsiya Mugtabarovna, Eduard Sagidullovich Gareev, Nika Eduardovna Valitova, Nursafa Gafurovna Khairullina in Oksana Vyacheslavovna Ustinova. Corporate Staff Identity as a Factor of Increasing Labor Productivity. Mediterranean Journal of Social Sciences 6 (5): 274-285.

Galbraith, John K. 1967. The Industrial State. London: Hamish Hamilton.

Gardner, Carl in Julie, Sheppard. 1989. Consuming Passion: The Rise of Retail Culture. London: Hamish Hamilton.

Gerber, Elizabeth M., Julie S. Hui in Pei-Yi Kuo. 20 12. Crowdfunding: Why people are motivated to post and fund projects on crowdfunding platforms. Proceedings of the International Workshop on Design, Influence, and Social Technologies: Techniques, Impacts and Ethics.

Gomezelj Omerzel, Doris, Roberto Biloslavo, Anita Trnavčevič. 20ı. Management znanja v visokošolskih zavodih. Koper: Fakulteta za Management.

Guba, Egon G. in Yvonna S. Lincoln. 1994. Competing paradigms in qualitative research. Handbook of qualitative research 2 (163-194): 105-I I 8.

Hancock, Peter A., Aaron A. Pepe in Lauren L. Murphy. 2005. Hedonomics: The Power of Positive and. Ergonomics in Design I3 (I): 8-I 4.

Harris, Fiona in Leslie de Chernatony. 2001. Corporate branding and corporate brand performance. European Journal of marketing 35 (3/4): 44I456.

Hatch, Mary Jo. 1993. The dynamics of organizational culture. Academy of management review i 8 (4): 657-693.

Hatch, Mary Jo in Majken Schultz. 2003. Bringing the corporation into corporate branding. European Journal of marketing 37 (7/8): I04I-I064.

Hatchuel, Armand in Benoit Weil. 2003. A new approach of innovative Design: an introduction to $\mathrm{CK}$ theory. In $\mathrm{DS}_{3}$ : Proceedings of ICED o3, the I4th International Conference on Engineering Design, Stockholm.

Hbr.https://hbr.org/2014/o4/the-art-of-corporate-endurance (I5. 4.2016).

Heskett, John. 20 I . Oblikovanje. Zelo kratek uvod. Ljubljana: Založba Krtina.

Heylighen Ann, Humberto Cavallin in Matteo Bianchin. 2009. Design in Mind. Design Issues. 25 (I): IO-I5.

Highhouse, Scott, Michael J. Zickar, Todd J. Thorsteinson, Sandra L. Stierwalt in Jerel Slaughter. 1999. Assessing company employment image: 
An example in the fast food industry. Personnel Psychology 52 (I): I5 I172 .

Hitka, Miloš, Milota Vetráková, Žaneta Balážová in Zuzana Danihelová. 2015. Corporate Culture as a Tool for Competitiveness Improvement. Procedia Economics and Finance 34: 27-3

Hofstede, Geert in Michael Minkov. 1991. Cultures and organizations: Software of the mind. London: McGraw-Hill.

Hsu, Greta in Michael T. Hannan. 2005. Identities, genres, and organizational forms. Organization Science i 6 (5): 474-490.

Ibarra, Herminia. 1999. Provisional selves: Experimenting with image and identity in professional adaptation. Administrative Science Quarterly 44 (4): 764-79I.

Jenkins, Julian. 2009. Creating the Right Enviroment for Design. V Design Thinking Integratign Innovation, Customer Ecperience, and Brand Value, ur. Thomas Lockwood, 23-33. New York: Allworth Press.

Johansson-Skoldberg, Ulla, Jill Woodilla in Mehves Cetinkaya. 2013. Design Thinking: Past, Present and Possible Futures. Creativity and Innovation management 22 (2): I 2 I-I 46.

Julier, Guy. 1998. The teapot: An appreciation. London: Aurum.

Julier, Guy. 2000. The culture of design. Sage Publications: London.

Julier, Guy. 2006. From Visual Culture to Design Culture. Design Issues 22 (I): 64-76.

Julier, Guy. 2013. From Design Culture to Design Activism. Design and Culture: The Journal of the Design Studies Forum S (2): 215-236.

Julier, Guy. 2014. The culture of design. London: SAGE.

Julier, Guy. B. 1. What is design culture? Http://www.designculture.info/main/ descultintro.htm (22. 4.2016).

Kaplan, Robert S. in David P. Norton. 2008. Mastering the management system. Harvard business review 86 (I): I-I 7 .

Kimbell, Lucy. 20 I I. Rethinking design thinking: Part I. Design and Cultu-

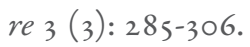

Knežević, Jelena. 20I4. The Contemporary reading of Schiller and aestheticization as a New Enlightment. Anglisticum Journal 3 (I):19-26.

Knight, E. 20I4. The art of corporate ednuracne. https://hbr.org/2014/o4/ the-art-of-corporate-endurance (15.3.2016).

Kolko, Jon. 2015. Design thinking comes of age. Harvard bussines review 93 (9): 66-7I. 
Konečnik Ruzzier, Maja. 20 I. Temelji trženja : pristop k trženjskemu načinu razmišljanja $v$ 2I. stoletju. Ljubljana: MeritUM.

Kotter John, P. in L. Heskett James. 1992 Corporate culture and performan$c e$. New York: The free Press.

Kralj, Niko. 1963. Merski standardi pri pohištvu. Les 5 (6): 80-82.

Kumar, Lalit Das. 2005. Clture as Designer. Design Issues 21 (4): 4I-53

Kvale, Steinar. 1996. InterViewing. London, Thousand Oaks in New Delhi: Sage.

Kvale, Steinar. 1996. InterViews: an introduction to qualitative research interviewing. London. Sage Publications, cop. 1996

Lee, Chong Joanna S. K. in Ron Benza. 2015. Teaching Innovation Skills: Application of Design Thinking in a Graduate Marketing Course. Business Education Innovation Journal 7 (I): 43-50.

Leiponen, Aija in Constance E. Helfat. 2010. Innovation objectives, knowledge sources, and the benefits of breadth. Strategic Management Journal 3 I (2): 224-236.

Likar, Borut, Dejan Križaj in Peter Fatur. 2006. Management inoviranja. Koper:Fakulteta za Management.

Lockwood, Thomas .2009. Creating the Right Enviroment for Design. V Design Thinking Integratign Innovation, Customer Ecperience, and Brand Value, ur. Thomas Lockwood, 23-33.New York: Allworth Press.

Luo, Yadong in Oded Shenkar. 2006. The multinational corporation as a multilingual community: Language and organization in a global context. Journal of International Business Studies 37: 32 I-339.

Luthans, Fred, Gretchen R. Vogelgesang in Paul B. Lester. 2006. Developing the psychological capital of resiliency. Human Resource Development Review 5 (I): 25-44.

Ma, Meng in Ritu Agarwal. 2007. Through a glass darkly: Information technology design, identity verification, and knowledge contribution in online communities. Information systems research i 8 (I): 42-67.

Marsick, Victoria J. in Karen E. Watkins. 2003. Demonstrating the value of an organization's learning culture: the dimensions of the learning organization questionnaire. Advances in developing human resources 5 (2): I32-I5I.

Mayring, Philipp. 2000. Forum: Qualitative Social Research. Qualitative Content Analysis 7 (I): 2-00. 
McEwan, Elaine K. in Patrick J. McEwan. 2003. Making sense of research: What's good, what's not, and how to tell the difference. Thousand Oaks: Corwin Press.

Mc Guirk, Justin. (201 I). Craft Fetishism. Http://justinmcguirk.com/craft-fetishism (24.3. 2016).

Miller, Daniel. 1987. Material Culture and Mass Consmption. Oxford: Basil Blackwell.

Mollick, Ethan R. in Venkat Kuppuswamy. 2014. After the campaign: Outcomes of crowdfunding. UNC Kenan-Flagler Research Paper 2376997.

Monfort, Abel, Ana Sebastián in Belén López. 2015. Corporate Identity In The Brand Co-Creation Era. Communication Papers 4 (8): 31-40.

Nelson Carl W. 2003. Review: Organizational Culture: Concept and Performance Cautions. Public performance and Management Review 27 (I):IO5-III.

Neumeier, Marty. 2008. The designful company. Design Management Review I9 (2): IO-I5.

Olins, Wally. 2002. Branding the nation-The historical context. The Journal of Brand Management 9 (4): 24I-248.

Oxford dictionary. B. 1. Http://www.oxforddictionaries.com/definition/english/trend (26. 4. 2016).

Palomaa, Katja. 2013. Material vision into fashion - Design, Branding and Innovation in the process of setting up a fashion label. Case Luxaa. Magistrska naloga. Rovaniemi: University of Lapland.

Payne, Adrian, Strobacka Kay, Frow Pennie in Simon Knox. 2009. Co-creating brands: Diagnosing and designing the relationship experience. Journal of Business Research 62 (3): 379-389.

Peper, Jürgen. 20 I 2. Ästhetisierung als Zweite Aufklärung. Eine literarästhetisch abgeleitete Kulturtheorie, Bielefeld: Aisthesis.

Perks, Helen, Rachel Cooper in Cassie Jones. 2005. Characterizing the Role of Design in New Product Development: An Empirically Derived Taxonomy. Journal of Product Innovation Management 22 (2): I I I-I 27.

Pham, Michel Tuan. 2013. The seven sins of consumer psychology. Journal of Consumer Psychology 23 (4): I-I3.

Pierce, Jon L. in Donald G. Gardner. 2004. Self-esteem within the work and organizational context: A review of the organization-based self-esteem literature. Journal of management 30 (5): 59I-622.

Pratt, Michael G., Kevin W. Rockmann in Jeffrey B. Kaufmann. 2006. Constructing professional identity: The role of Work and Identity Learning 
Cycles in the Customization of Identity amond Medical Resiodents. The academy of management Journal 49 (2):235-262.

Predan Barbara in Špela Šubic. 20 I. Niko Kralj: Neznani znani oblikovalec. Ljubljana: Muzej za arhitetkuro in oblikovanje.

Ravasi, Davide in Gabreilla Lojacono. 2005. Managing design and designers for strategic renewal. Long Range Planning 38(I): 5 I-77.

Razzouk, Rim in Valerie Shute. 20I 2. What is design thinking and why is it important?. Review of Educational Research 82 (3): 330-348.

Red Dot. B. 1. Http://En.Red-Dot.Org/ (10. 2. 2016).

Rosenberg, Nathan Owen Sr., Marie-Caroline Chauvet in Jon S. Kleinman. 2015. Design Thinking: New Product Development Essentials from the PDMA. Hoboken: John Wiley \& Sons.

Ross, Nigel. 2015. Design thinking: Understanding how designers think and work. Oxford: Berg.

Rowe, Peter G. 1991. Design thinking. Cambridge: MIT press.

Roy, Robin in Johann Ckh Riedel. 1997. Design and innovation in successful product competition. Technovation 17 (I0): 537-594.

Roy, Robin in Stephen Potter. 1993. The commercial impacts of investment in design. Design studies I 4 (2): I7 I-193.

Russell, Brenda, Delara Motlagh in William W. Ashley. 2000. Form follows function: how muscle shape is regulated by work. Journal of Applied Physiology 88 (3) : I I 27-I I 32.

Russell-Bennett, Rebekah in Steve Baron. 2015. Fresh thinking in services marketing: contemporary, cutting-edge and creative thoughts. Journal of Services Marketing 29 (6/7): 42 I - 424.

Saez-Trumper, Diego, Giovanni Comarela, Virgílio Almeida, Ricardo Baeza-Yates in Fabrício Benevenuto. 201 2. Finding trendsetters in information networks. Proceedings of the I8th ACM SIGKDD international conference on Knowledge discovery and data mining ACM: IOI4-IO22.

Sagadin, Janez. 2004. Tipi in vloga študij primerov v pedagoškem raziskovanju. Sodobna pedagogika 55 (4): 88-100.

Salecl, Renata. 20ı . (Per) verzije ljubezni in sovraštva. Ljubljana: Mladinska knjiga Založba.

Salecl, Renata. 2012. Izbira. Ljubljana : Cankarjeva založba.

Schein, Edgar H. 2004. Organizational culture and leadership. San Francisco: Jossey-Bass. 
Schultz, Majken in Leslie De Chernatony. 2002. Introduction: The Challenges of Corporate Branding. Corporate Reputation Review 5 (2-3): 105I 2.

Schultz, Majken in Mary Jo Hatch. 1996. Living with multiple paradigms the case of paradigm interplay in organizational culture studies. Academy of management review 2 I (2): 529-557.

Schultz, Majken, Mary Jo Hatch in Larsen Mogens Holten. 2000. The Expressive organisation.Linking Identity, Reputation, and Corporate Brand. New York: Oxford University Press.

Shepard, Lorrie A. 2000. The role of assessment in a learning culture. Educational researcher 29 (7): 4-I 4 .

Sherwood John J. 1965. Self Identity and Referent Others. Sociometry 28 (I): 66-8I.

Silverman, David. 200I. Doing qualitative research: a practical handbook. London: Sage.

Simmel, Georg. 1957. Fashion. American journal of sociology 65 (6): 54 I-558.

Simons, Helen. 2009. Case study research in practice. London: SAGE Publications.

SSKJ. B. 1. Http://bos.zrc-sazu.si/cgi/ao3.exe?name=sskj_testa\&expressio$\mathrm{n}=$ izpopolniti\&hs $=7$ (26.4. 2016).

Stake, Robert E. 2013. Multiple case study analysis. New York: Guilford Press.

Starman, Adrijana B. 2013. Študija primera kot vrsta kvalitativne raziskave. Sodobna pedagogika 64 (I): 66-8I.

Staub, Selva, Ramazan Kaynak in Tarkan Gok. 2016. What affects sustainability and innovation-Hard or soft corporate identity?. Technological Forecasting and Social Change 102: 72-79.

Sternberg, Robert J. 2006. The nature of creativity. Creativity Research Journal i 8 (I): 87-98.

Strauss, Anselm in Juliet Corbin. 1990. Basics of qualitative research. Newbury Park, CA: Sage.

Suwa, Masaki, J. S. Gero, and Terry Purcell. 1999. Unexpected discoveries and s-inventions of design requirements: A key to creative designs. Computational Models of Creative Design IV, Key Centre of Design Computing and Cognition, University of Sydney, Sydney, Australia.

Swap, Walter, Dorothy Leonard in Lisa Abrams Mimi Shields. 200ı. Using mentoring and storytelling to transfer knowledge in the workplace. Journal of management information systems I8 (I): 95-I I 4 . 
Swink, Morgan. 2000. Technological innovativeness as a moderator of new product design integration and top management support. Journal of Product Innovation Management I7 (3) : 208-220.

Syafii, Lukman Imam, Armanu Thoyib in Umar Nimran. 2015. The Role of Corporate Culture and Employee Motivation as a Mediating Variable of Leadership Style Related with the Employee Performance (Studies in Perum Perhutani). Procedia-Social and Behavioral Sciences 2I I: I I 42-I I 47.

Szczepańska-Woszczyna, Katarzyna. 2015. Leadership and Organizational Culture as the Normative Influence of Top Management on Employee's Behaviour in the Innovation Process. Procedia Economics and Finance 34: 396-402.

Škerlavaj, Miha, Mojca Indihar Štemberger in Vlado Dimovski. 2007. Organizational learning culture - the missing link between business process change and organizational performance. International Journal of Production Economics 106(2): 346-367.

Teece, David J. 20ı. Business models, business strategy and innovation. Long range planning 43 (2): 172-194.

Tellis, Gerard J., Jaideep C. Prabhu in Rajesh K. Chandy. 2009. Radical innovation across nations: The preeminence of corporate culture. Journal of marketing 73 (I): 3-23.

Trompenaars, Fons in Charles Hampden-Turner. 1998. Riding the waves of culture. New York: McGraw-Hill.

Tucker, Conrad S. in Harrison M. Kim. 201 .Trend mining for predictive product design. Journal of Mechanical Design I33 (I): I I Ioo8.

Urde, Mats. 200 I. Core value-based corporate brand building. European Journal of Marketing 37 (7-8): 1017-1040.

Veblen, Thorstein. 2007. The theory of the leisure class. OUP Oxford.

Verbeek, Peter-Paul. 2010. What things do: Philosophical reflections on technology, agency, and design. Penn State Press.

Vitta Maurizio in Juliette Nelles. 1985. The meaning of Design. Dessign Issuses $2(2): 3-8$.

Vorhies, Douglas W. in Neil A. Morgan.2005. Benchmarking marketing capabilities for sustainable competitive advantage. Journal of marketing 69 (I): $80-94$.

Warde, Alan. 2005. Consumption and theories of practice. Journal of Consumer Culture s (2): I3 I-I53. 
Warde, Alan. 2014. After taste: Culture, consumption and theories of practice. Journal of consumer culture i 4 (3): 279-303.

Woudhuysen, James. 20 I I. The next trend in design. Design Management Journal 6 (I): 27-39.

Yin, Robert K. 2001. Case study research. Design and methods. Thousand Oaks, London, New Delhi: Sage Publications.

Zhou, Kevin Zheng, Chi Kin Yim in David K. Tse. 2005. The effects of strategic orientations on technology-and market-based breakthrough innovations. Journal of marketing 69 (2): 42-60. 


\section{Stvarno kazalo}

D

design culture 23, I07, I09, IIO, III, II 8 designerly thinking II, 43, 44, 45, 92, 99 ,

I07

design managementa $\mathbf{1 0}, \mathbf{I I}, \mathbf{9 8}$

design thinking II, I2, 43, 44, 45, 92, 99 , 107, 109, 115, 118, I2I

dizajnerska kultura II, I3, 19, 48, 99, 100 dizajnersko razmišljanje $\mathbf{I I}, \mathbf{4 8 , 9 9}$

I

identiteta II, 19, 20, 21, 26, 28, 29, 31, 32, $33,34,42,60,61,62,64,65,67,68$, 69, 71, 73, 78, 84, 86, 89,90, 93 ,

94,99

inoviranje II, I2, 19, 4I, 45, 6I, 63, 69, 7I, $72,77,78,83,92,93,94,95,99$, IOO, 119

K

korporativna kultura II, 13, I8, 19, 20, 2 I, $33,68,76,99$, IOI

kultura 9, 10, I1, 12, 13, 14, 15, 17, 18, 19, $20,21,22,23,24,25,26,27,28,29$, $30,31,33,34,35,38,39,40,41,42$, $43,45,48,49,50,51,52,53,56,58$,
$59,62,64,65,66,67,68,69,70,71$, $72,73,74,75,76,77,78,79,85,88$, $89,90,91,92,93,94,95,97,98,99$, IOO, $101,102,103,114$

kultura oblikovanja 23, 34, 35, 69

M

menedžerski vidik 37, 4I, 45

O

oblikovalski vidik $\mathbf{1 7}, 37,4 \mathbf{1}, 8$ O

oblikovanje Io, 14, 15, 21, 22, 23, 24, 25 , $26,28,29,30,32,36,37,38,39,40$, 4I, 42, 44, 45, 46, 48, 49, 50, 5I, $54,55,58,60,62,63,64,65,66,67$, $68,69,70,71,72,73,75,78,79,8$, $8 \mathrm{I}, 82,83,87,88,89,91,92,93,94$, 95, $98,102,103,116,117,121$ organizacijska kultura IO, 12, 13, 19, 20, 98, IOO, IOI

P

potrošništvo 9, 26, 27,97

potrošnja 23, 24, 26, 27, 4I 
Dizajnerska kultura in nagrada za oblikovalske dosežke

$\mathrm{R}$

Red Dot Design Award 14, 48, 52, 101,

IO2, 110

$\mathrm{V}$

vrednotni sistem IO, I8, 98

Z

znamčenje IO, II, 12, 21, 22, 26, 31, 34, 42, $48,71,83,84,86,87,88,89,94,98$,

99, 100

znamka I2, 21, 31, 32, 34, 38, 62, 85, 86,

89,100 



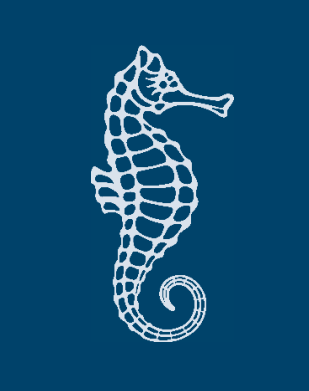

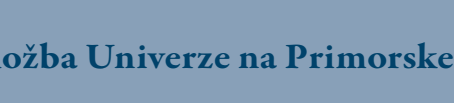

